San Jose State University

SJSU ScholarWorks

Master's Theses

Master's Theses and Graduate Research

Summer 2017

\title{
Spatial Distribution of Artesian Conditions within the Niles Cone Basin, Alameda County, California
}

Anthony Wade Fisher

San Jose State University

Follow this and additional works at: https://scholarworks.sjsu.edu/etd_theses

\section{Recommended Citation}

Fisher, Anthony Wade, "Spatial Distribution of Artesian Conditions within the Niles Cone Basin, Alameda County, California" (2017). Master's Theses. 4845.

DOI: https://doi.org/10.31979/etd.j69c-e53k

https://scholarworks.sjsu.edu/etd_theses/4845

This Thesis is brought to you for free and open access by the Master's Theses and Graduate Research at SJSU ScholarWorks. It has been accepted for inclusion in Master's Theses by an authorized administrator of SJSU ScholarWorks. For more information, please contact scholarworks@sjsu.edu. 


\title{
SPATIAL DISTRIBUTION OF ARTESIAN CONDITIONS WITHIN THE NILES CONE BASIN, ALAMEDA COUNTY, CALIFORNIA
}

\author{
A Thesis \\ Presented to \\ The Faculty of the Department of Geology \\ San José State University \\ In Partial Fulfillment \\ of the Requirements for the Degree \\ Master of Science
}

by

Anthony W. Fisher

August 2017 
(C) 2017

Anthony W. Fisher

ALL RIGHTS RESERVED 
The Designated Thesis Committee Approves the Thesis Titled

SPATIAL DISTRIBUTION OF ARTESIAN CONDITIONS WITHIN THE NILES CONE BASIN, ALAMEDA COUNTY, CALIFORNIA

\author{
by \\ Anthony W. Fisher \\ APPROVED FOR THE DEPARTMENT OF GEOLOGY \\ SAN JOSE STATE UNIVERSITY
}

August 2017

June A. Oberdorfer, Ph.D. Department of Geology

Manny J. Gabet, Ph.D. Department of Geology

Douglas T. Young, M.S. Alameda County Water District 


\title{
ABSTRACT \\ SPATIAL DISTRIBUTION OF ARTESIAN CONDITIONS WITHIN THE NILES CONE BASIN, ALAMEDA COUNTY, CALIFORNIA
}

\author{
by Anthony W. Fisher
}

The Niles Cone Basin (NCB) within Alameda County, California, contains portions of the basin under perennial and ephemeral artesian groundwater conditions. This study used 349 wells installed throughout the basin's four-aquifer system to delineate the spatial distribution of the 86 wells that have gone artesian between 1995 and 2015. Artesian wells within all four aquifers occur at elevations below 5.2 meters above sea level (MASL) but predominantly below 3.0 MASL. Even at lower elevations, artesian conditions do not occur in regions of major pumping owing to significant drawdown. Within topographically-low regions, wells may not be artesian where well-heads are located at higher elevations, such as on a levee or other elevated landforms. This can be observed throughout the Newark and Centerville aquifers where artesian wells are located near non-artesian wells during the same monitoring event. Precipitation influences artesian conditions with artesian events correlated with increases in precipitation generally during, but not limited to, the early spring months. The water levels of the shallow Newark Aquifer were found to respond independently from the three deeper aquifers. Those deeper aquifers were observed to be in hydraulic connection with one another, displaying synchronous water level changes with time across the basin. 


\section{ACKNOWLEDGMENTS}

I would like to give a special thanks to my thesis advisor Dr. June Oberdorfer. Throughout the entirety of my thesis process, she was always there to help me on a minute's notice. Her expansive expertise in the field of hydrogeology made her a vital resource throughout my research. Thanks to Douglas Young for not only giving me the opportunity to work on this project for the Alameda County Water District, but for providing me with guidance and teaching me a great deal about the hydrogeology of the Niles Cone Basin while interning at the Alameda County Water

District. Thanks to Manny Gabet for his time and help during his last-minute substitution onto my thesis committee. Additional thanks go out to groundwater resource engineers Tom Berkins and Selim Zyrek of the Alameda County Water District for their mentoring during my internship. Their guidance and support will be something I carry on into the next chapter of my life and will not be forgotten. Thanks to all of the faculty and staff at San Jose State University as well as those at my alma mater, San Diego State University. Thanks to my friends and family including my mother Gail Fisher, father Jim Fisher, sister Whitney Fisher, and mother-in-law Merideth Pistulka, who have always been there for me. Last but not least, I want to express my deepest gratitude to my fiancée Madisyn Pistulka, who pushed me to pursue my master's degree, as well as for her constant support and love throughout my graduate studies. 


\section{TABLE OF CONTENTS}

List of Tables................................................................................ ix

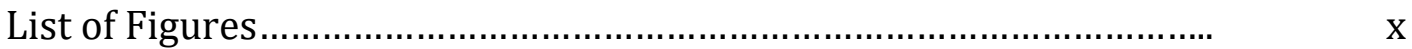

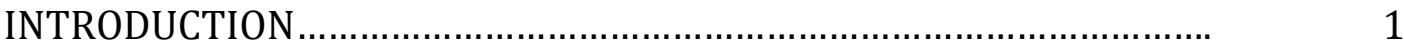

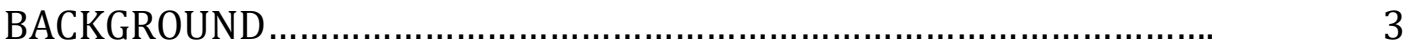

Artesian Conditions........................................................................

Previous Studies....................................................................

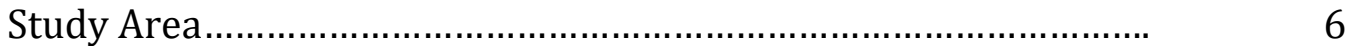

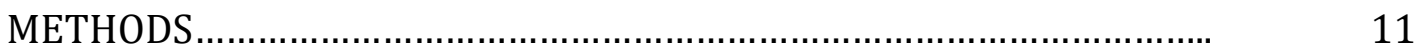

Groundwater Level Data ...........................................................

Data Quality Review.................................................................

Map Representations................................................................

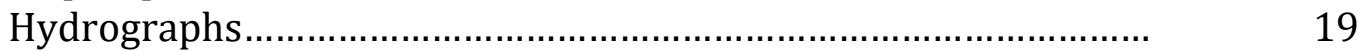

Comparison with Inputs and Outputs............................................. 19

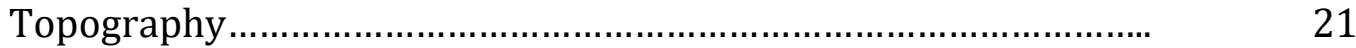

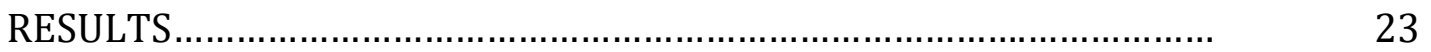

Spatial Distribution of Artesian Wells...........................................

Newark Aquifer.............................................................

Centerville Aquifer............................................................

Fremont Aquifer....................................................................

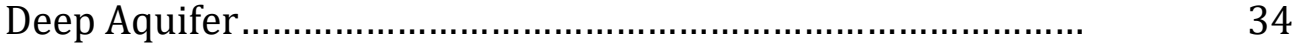

Topography.....................................................................

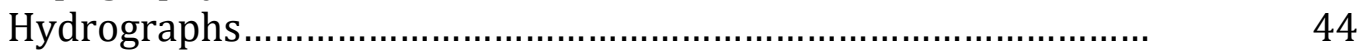

Group A

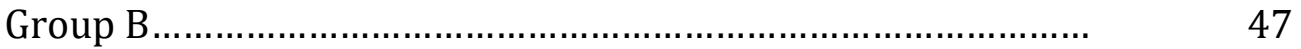

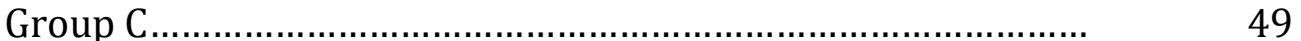

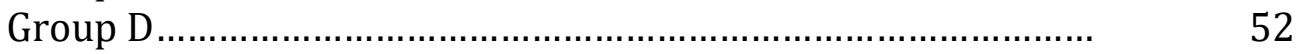

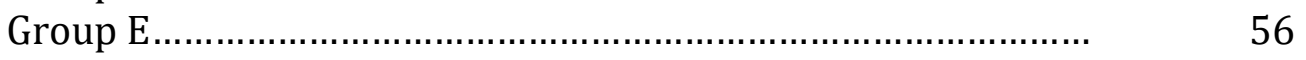

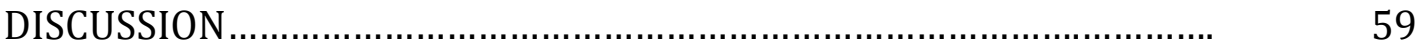

Factors Controlling Artesian Conditions......................................... $\quad 59$

Topography ................................................................... $\quad 59$

Groundwater Inputs and Outputs.........................................

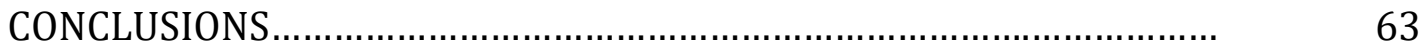


REFERENCES CITED ............................................................ 65

APPENDIX A: NCB Sub-Region (1-24) Hydrographs............................ 67

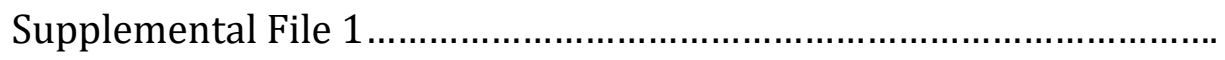




\section{LIST OF TABLES}

Table 1. Newark Aquifer well-network monitoring statistics........ 28

Table 2. Centerville Aquifer well-network monitoring statistics... $\quad 32$

Table 3. Newark Aquifer adjacent wells..................................... $\quad 43$

Table 4. Centerville Aquifer adjacent wells............................... 44 


\section{List of Figures}

Figure 1. Study area displaying NCB boundary .............................. 2

Figure 2. Confined/Unconfined aquifer system............................. $\quad 4$

Figure 3. ACWD map with Quarry Lake recharge ponds, ARP wells, production wells, and city locations..................... $\quad 7$

Figure 4. Cross-section of the NCB ............................................ 10

Figure 5. Map of twenty-four sub-regions.................................... 17

Figure 6. Map of five well Groups (A-E) ....................................... 18

Figure 7. Multi-aquifer well map............................................... 24

Figure 8. Newark Aquifer artesian and non-artesian events........ 26

Figure 9. Centerville Aquifer artesian and non-artesian events... 30

Figure 10. Fremont Aquifer artesian and non-artesian events....... 33

Figure 11. Deep Aquifer artesian and no-artesian events............... 35

Figure 12. Newark Aquifer wells with labeled TOC reference elevations .................................................................... 37

Figure 13. Centerville Aquifer wells with labeled TOC reference elevations ................................................................. 38

Figure 14. Fremont Aquifer wells with labeled TOC reference elevations..................................................................... 39

Figure 15. Deep Aquifer wells with labeled TOC reference elevations.................................................................... 40

Figure 16. NCB reference point elevation contour map.................. 41

Figure 17. Group A DTW hydrographs with total yearly precipitation. 
Figure 18. Group B DTW hydrographs with total yearly

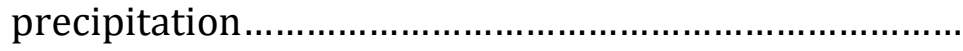

Figure 19. Group C DTW hydrographs with total yearly precipitation...

Figure 20. Group D DTW hydrograph with total yearly

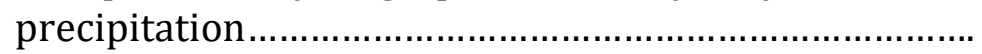

Figure 21. Group D DTW hydrographs with NCB BHF sub-basin total yearly pumping...................................................

Figure 22. Group E DTW hydrographs with total yearly precipitation.................................................................... 


\section{INTRODUCTION}

Semianually, the Alameda County Water District (ACWD) conducts spring and fall groundwater monitoring within ACWD's boundary overlying the Niles Cone Basin (NCB) (Fig. 1). The ACWD Groundwater Monitoring Program was initiated in 1961 to systematically monitor groundwater conditions, ensuring proper basin management (ACWD, 2016). Data acquired from the ACWD were partially supported and funded by the State of California Department of Water Resources (DWR). The NCB consists of an immense and complex system of varying lithology and hydrostratigraphy, comprised of several large semi-confined alluvial aquifers containing fresh water from imported sources and local runoff as well as brackish water intruding from the western margins of the basin's boundary. Throughout the $\mathrm{NCB}$, artesian conditions (defined as a potentiometric surface above the ground surface) are observed along with springs that flow periodically, despite diminished precipitation over the last four years of drought through 2016. Using data from the ACWD's Spring and Fall Groundwater Monitoring Reports (GWMR), as well as their complete groundwater database, this thesis attempted to analyze the hydrogeology of the basin, focusing on water inputs and outputs, to determine why certain monitoring wells in the basin are under higher positive pressure (artesian flowing conditions) compared to areas that are not. The NCB supplies approximately $36 \%$ of ACWD's water to the cities of Fremont, Newark, and Union City (ACWD, 2015). 


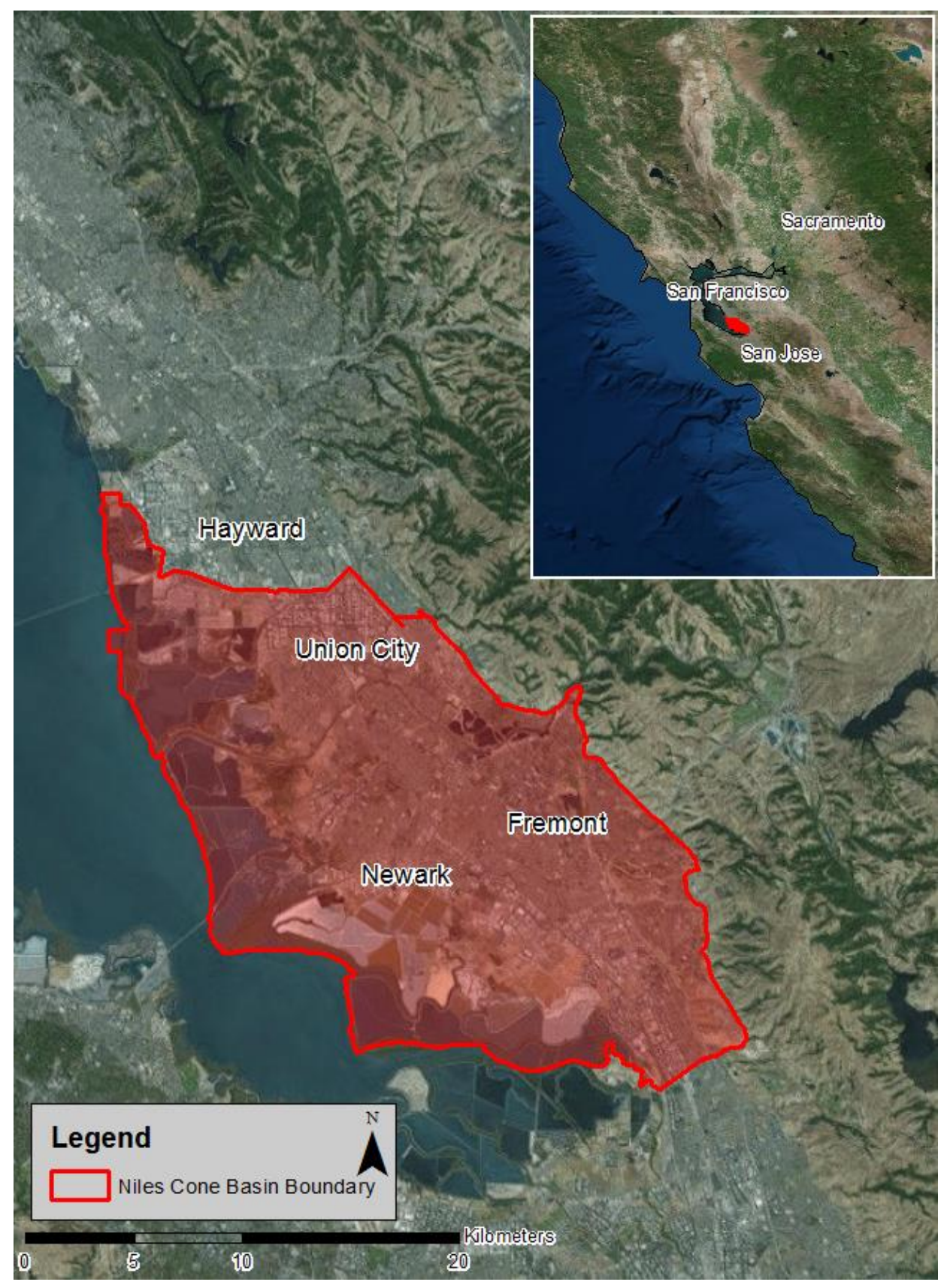

Figure 1. Study area displaying NCB boundary.

Understanding artesian conditions within the NCB further expands our knowledge of the basin in order to help protect and manage the NCB's groundwater resources. 


\section{BACKGROUND}

\section{Artesian Conditions}

Artesian conditions are a complex interaction between geology, lithology, water inputs and outputs, and topography. In this thesis, the term "artesian" refers to hydrodynamic conditions in which a confined aquifer is under positive pore-water pressure and where the potentiometric surface is above or at the ground surface (Klimchouk, 2005). Artesian conditions result from permeable material that holds

water under positive pressure. The permeable water-bearing zone must be overlain by an aquitard or aquiclude that impedes or prevents the upward migration of water from the confined aquifer (Fig. 2). The build-up of positive pressure within the confined water-bearing zone is a result of up-gradient loading of groundwater caused by infiltration of precipitation and runoff. Water recharging a confined system at a topographic high, where there is a suitable permeable exposure, introduces pressure down-gradient within the system, creating an increase in potentiometric surface. Once increased pressure within the system brings the potentiometric surface above the ground surface at a well, artesian conditions exist. 


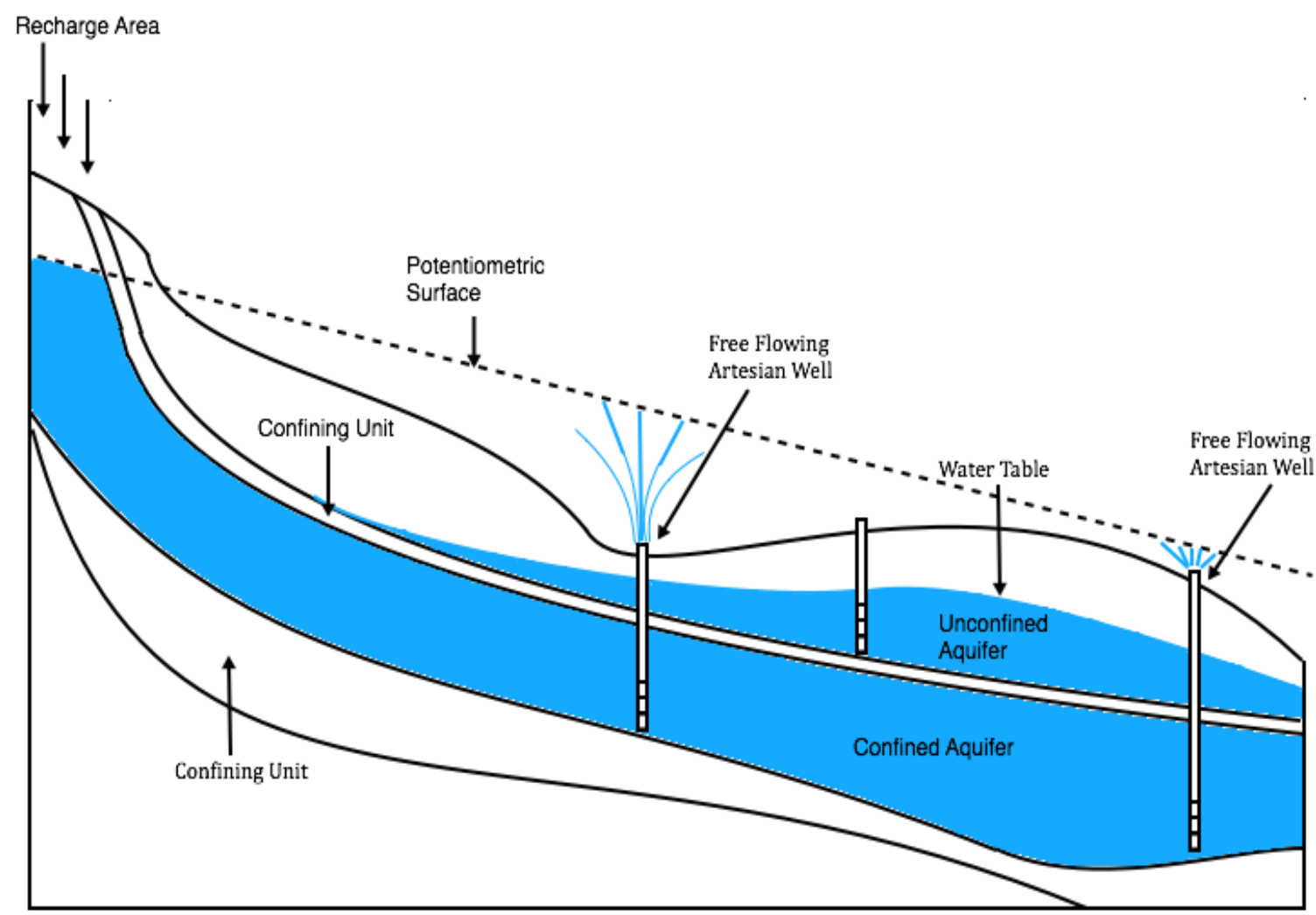

Figure 2. Confined/Unconfined aquifer system. This study will be focused on "free flowing artesian well" conditions in this diagram and not the "artesian" well conditions.

\section{Previous Studies}

Artesian conditions within groundwater systems have been quantified and documented early on by Chamberlin (1885) in his Requisite and Qualifying Conditions of Artesian Wells. Chamberlin's work has been referenced numerous times in scholarly papers pertaining to the hydrology of artesian systems. Today, the general understanding of artesian groundwater is widely accepted.

Unfortunately, studies focusing on the causes and spatial variability of artesian groundwater within alluvial-fill basins are scarce. Zhang (2001) used a neighborhood statistical approach to predict the spatial occurrence of artesian 
conditions based upon previous locations of artesian well data. The study concluded that regional geological, topographical, and hydrogeological features influence artesian conditions.

In Clark's 1924 paper, artesian conditions within the Santa Clara Valley were briefly studied. The paper discussed structural features within the valley that contributed to artesian conditions. Inclined structural features were referenced as a necessity in promoting the downward migration of groundwater to a lowerelevation portion of the valley, causing the build-up of artesian pressure within a system. Within the Santa Clara Valley, inclined structures that produced artesian pressure were that of axial and lateral stream deposits, forming down-gradient permeable strata to the coastal margins of the valley. Lastly, the paper touched upon the importance of seasonal fluctuations in artesian pressure brought upon by variations in precipitation, resulting in increases and decreases in the potentiometric surface.

Groundwater basin management throughout the South San Francisco Bay basins (SFBRWQCB, 2003) has documented occurrences of artesian groundwater conditions. Information is typically limited to the number of wells that may be artesian out of a collective total in a study, neglecting causation such as geologic and topographic influences. Based on an extensive search of literature focusing on artesian conditions within alluvial basins, it is evident that more work needs to be undertaken to truly understand artesian systems. 


\section{Study Area}

The ACWD is a public agency within the state of California that is responsible for the protection and management of water resources within the ACWD's geographic area, which encompasses approximately 270 square-kilometers $(67,000$ acres $)$ (ACWD, 2015). ACWD services approximately 340,000 people by providing potable water that surpasses all state and federal drinking water standards throughout the cities of Fremont, Newark, and Union City (ACWD, 2015). The ACWD has several water supply sources including purchased water from the State Water Project via the South Bay Aqueduct, the San Francisco Public Utilities Commission via the Hetch Hetchy aqueduct system, water produced from ACWD wellfields, the Newark desalination plant, and surface runoff. The ACWD has relied on alternative sources of water to ensure a stable water supply to the ACWD's service area (SFBRWQCB, 2003). Alternative sources of water within the NCB include artificial recharge from the ACWD Quarry Lakes percolation ponds, which are located within the forebay of the basin near Alameda Creek (Fig. 3). 


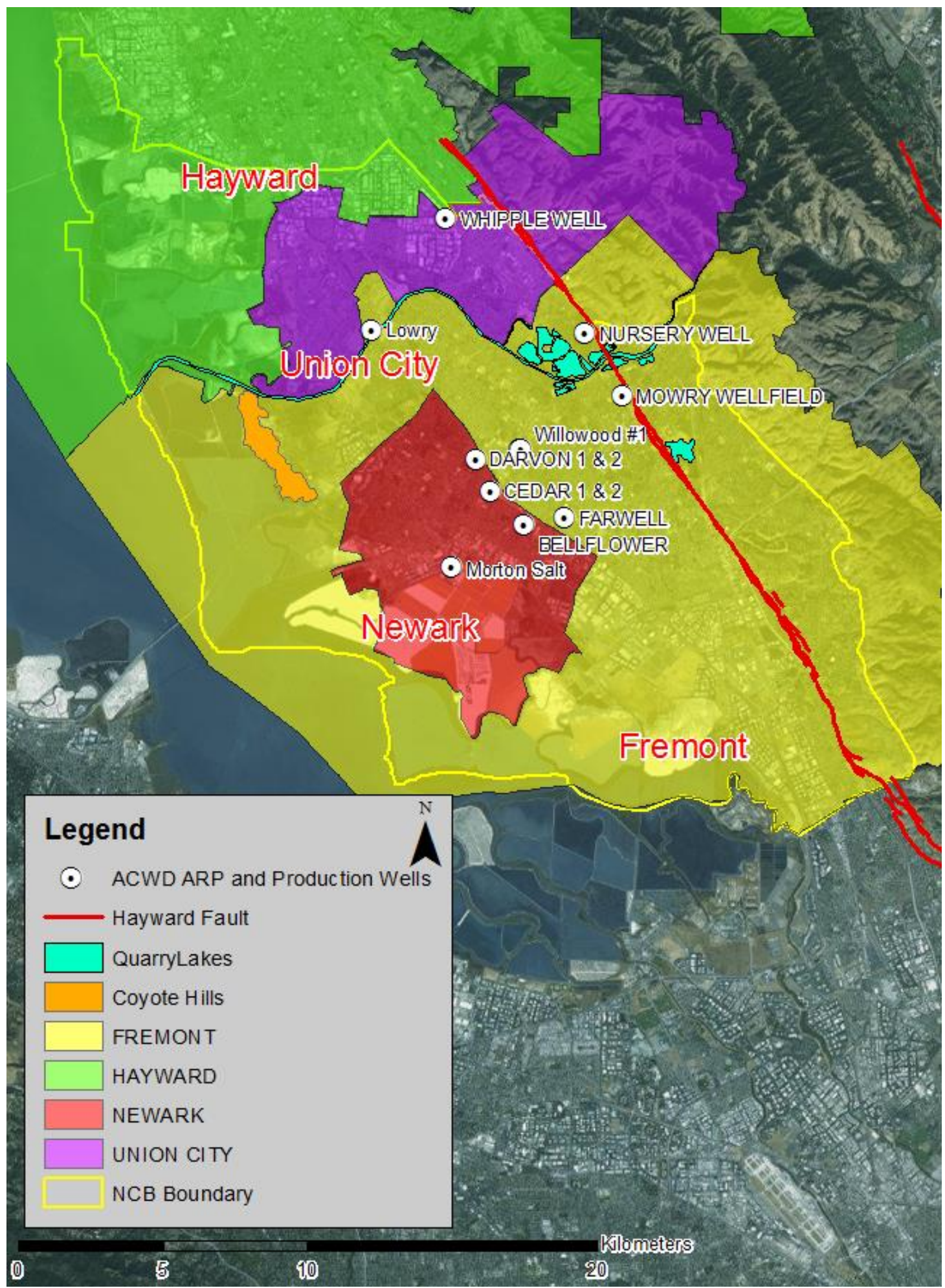

Figure 3. Map of ACWD with Quarry Lake recharge ponds, ARP wells, production wells, and city locations. 
Nearly all of the NCB is included within ACWD's boundaries as delineated by the DWR. The NCB is bound on the east by the Diablo Range and on the west by the San Francisco Bay (SFBRWQCB, 2003). The NCB boundary incorporates Union City and Fremont to the north, and Fremont to the south. The NCB is contained within alluvial fan deposits that were formed from sediments derived from Alameda Creek as it exits the Diablo Range and flows toward San Francisco Bay. Additionally, the formation of the NCB was influenced by interfingering marine deposits from San Francisco Bay. The water-bearing materials consist of Quaternary alluvium, including unconsolidated gravel, sand, silt, and clay. The right-lateral, strike-slip Hayward fault transects the apex of the alluvial fan, striking to the north-northwest and creating an effective impediment to the lateral movement of groundwater (DWR, 1967). The area to the east of the fault towards the base of the foothills is generally referred to as the Above Hayward Fault (AHF) sub-basin, and the region of the basin to the west of the fault is referred to as the Below Hayward Fault (BHF) sub-basin. The entirety of the BHF sub-basin encompasses this project's study area. A measured groundwater elevation difference of approximately $12 \mathrm{~m}$ has been measured across the fault at nearby wells (4S/1W-28C016 measured on 8/26/2014 and 4S/1W-21P004 measured on 8/25/2015), attesting to the low permeability of the Hayward fault.

The hydrogeology of the basin is quite complex, resulting from alluvial deposits creating gently westward-dipping aquifers separated by clay aquitards (ACWD, 2007b). The water-bearing formations of the NCB have been separated into four 
main alluvial aquifers: the Newark, the Centerville, the Fremont, and the Deep (Fig. 4). Portions of the Centerville and Fremont Aquifers are semi-confined with discontinuities in the separating clay layers. Where the clay layers are discontinuous, the combined aquifer is referred to as the Centerville-Fremont. In addition to discontinuities within aquitards, old abandoned agriculture wells create interconnectivity between the two water-bearing zones (SFBRWQCB, 2003). As referenced in DWR's 1967 Bulletin 118, the Newark Aquifer is the shallowest water-bearing formation, ranging from 12 to 43 meters below ground surface (mbgs); it is comprised of an extensive, permeable, gravel lithology. The Centerville Aquifer lies beneath the Newark Aquifer at a depth of approximately 55 to $61 \mathrm{mbgs}$ with a range in thickness between 3 and $30 \mathrm{~m}$. The lithology of the Centerville Aquifer is composed mostly of sand and gravel. The Fremont Aquifer is distributed below the Centerville, varying in depth from 91 and 119 mbgs. Although the Fremont Aquifer's lithology and stratigraphy is not as well defined as those of the shallower aquifers, limited well-log data has shown the Fremont Aquifer to be composed of sand and gravel. There are a series of deeper aquifers within the NCB that are classified as the Deep Aquifer varying in depth from 122 up to at least 152 mbgs. 


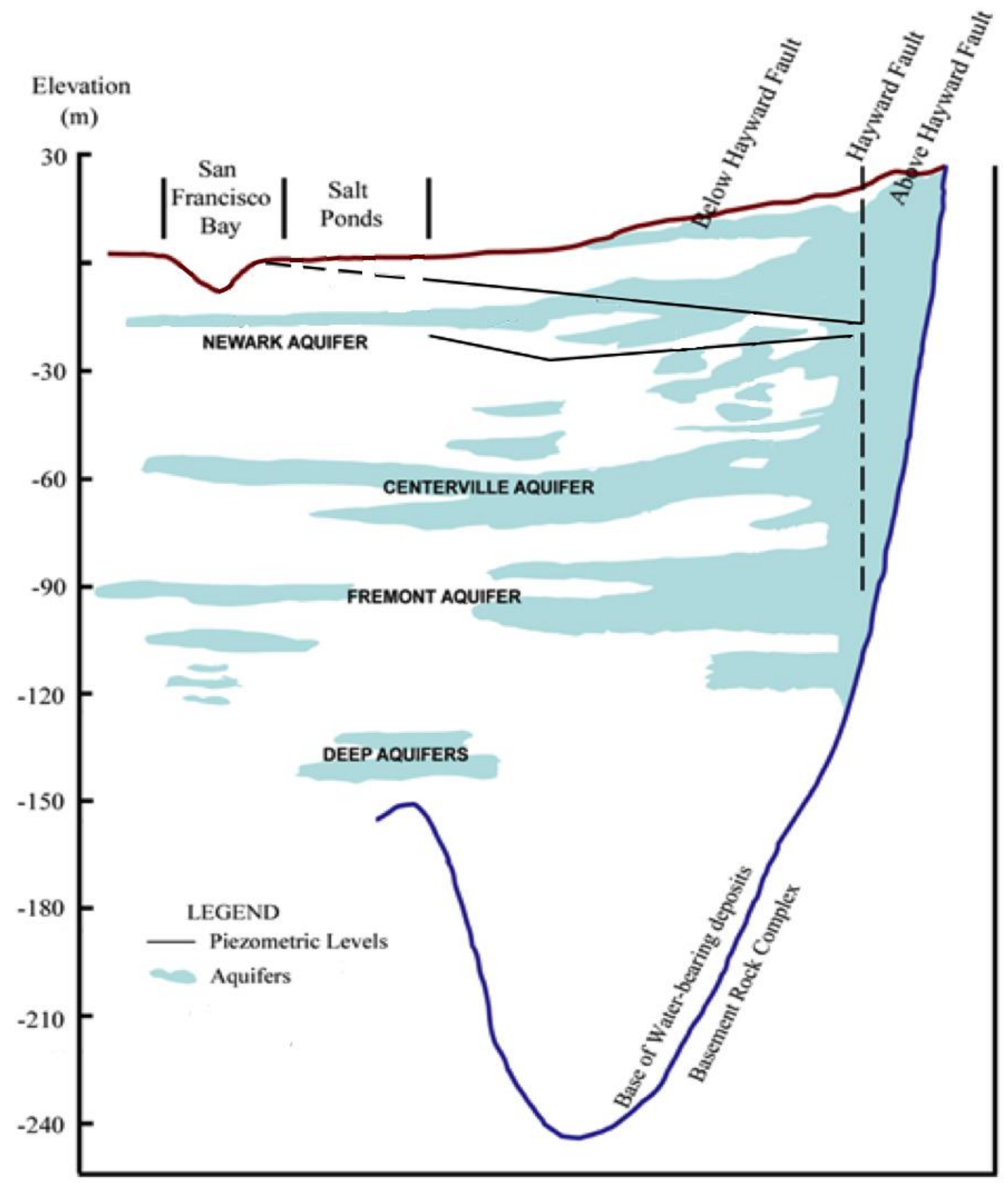

Figure 4. Cross-section of the NCB (modified from ACWD, 2015). 


\section{METHODS}

\section{Groundwater Level Data}

This research is based upon monitoring-well, water-level data acquired from ACWD as collected seasonally and documented in ACWD's Groundwater Monitoring Reports (ACWD, 2002 through 2016) as well as in the ACWD's complete groundwater database. Seasonal monitoring data from ACWD's groundwater data set focuses on lower precipitation months (August and September) and higher precipitation months (March and April) to study seasonal groundwater-elevation responses to varying water fluxes. ACWD provided their complete groundwater monitoring dataset, and the subset spanning 1995 to 2015 was selected for use. The study period 1995 to 2015 was selected to ensure the accuracy of the monitoring well, water-level data. Monitoring well groundwater-elevation data prior to 1995 do not have a clear record of a consistent reference point elevation, which may potentially give unreliable depth to water (DTW) values compared to monitoring well, groundwater-elevation data beginning in 1995. DTW is one of the key measurements utilized to determine whether or not a well was artesian. DTW for each well was calculated from ACWD's groundwater-elevation data by subtracting the groundwater elevation, using sea level as a datum, from the standard well measuring point, the top of the well casing (TOC). This result gave a length measurement, either below or above the TOC. DTW values that are equal to or less than $0.3 \mathrm{~m}(\sim 1 \mathrm{ft}$.) have been designated as free-flowing or near-free-flowing artesian conditions and will be the focus of this paper. This criterion was selected 
because a value less than or equal to $0.3 \mathrm{~m}$ is sufficient to represent near freeflowing conditions within the basin, defining regions under higher groundwater pressure.

Well-screened intervals were examined to identify the aquifer in which a specific well was screened. Well-screened intervals measured in mbgs for monitored wells along with the aquifer in which a well is screened were acquired from ACWD. Monitoring wells that either had a partially completed construction log or were missing a log completely were removed from the study. In addition to poorly documented well-construction logs, various wells were screened in multiple aquifers or within portions of the basin with discontinuities between vertical confining layers. An example of this occurs within the forebay region near the Hayward fault: this region is comprised mostly of an extensive gravel lithology that spans from the Newark Aquifer vertically into the Deep Aquifer interconnecting each of the four alluvial aquifer systems.

For wells screened across multiple aquifers, wells within the hydrographs were labeled by whichever aquifers the wells were screened in (i.e., Centerville and Fremont were denoted by “CF” within the hydrograph legend). Within ArcGIS aquifer maps, wells that were screened within Newark and Centerville were denoted as Newark, Centerville and Fremont were denoted as Centerville, Fremont and Deep were denoted as Fremont, and Centerville, Fremont, and Deep were denoted as Deep. 


\section{Data Quality Review}

Data collected by ACWD were evaluated to make sure any erroneous or anomalous water-level measurements were removed from the analysis. Variance within ACWD's extensive complete groundwater database could be readily observed and anomalous data identified visually within created hydrographs. Anomalous data were subsequently removed. Any well that was provided for analysis went through an initial examination of its measurement data focusing on two parts:

1. Well Reference Point Elevation: Many wells were found to have reference point elevations equal to zero. This appeared to be a place-holder value for data that most likely was left blank as an unknown reference point elevation. There does not appear to be any location within the study area that has a TOC reference point elevation equal to sea level, even for wells adjacent to the San Francisco Bay or within lower-lying depressions. As a result, wells having a well reference point elevation equal to zero were removed from the study.

2. Groundwater Elevation: Similar to well reference point elevation, many wells were found to sporadically contain groups of groundwater elevations equal to zero. This appears to be a generic place-holder value for any wells that did not have a value entered for groundwater elevation. In order to preserve accuracy, monitoring well groundwater-elevation values that were equal to zero were removed from the study's database.

In addition to erroneous and anomalous groundwater data, original data 
acquired from ACWD's groundwater database had data limitations with respect to the spatial and temporal distribution of measurements. Some wells were monitored intensively while others more sporadically so that there were disparities in the number of wells sampled during each monitoring event. To address this variability, monitoring wells selected for study needed to have relatively consistent monitoring for at least a portion of the study period from 1995 to 2015.

\section{Map Representations}

Maps were created within ArcGIS to examine the spatial distribution of artesian wells while targeting and defining variables based on locale that may contribute to higher positive pressure within specific regions of the basin, both laterally and vertically. First, a multi-aquifer well-map containing all artesian and non-artesian wells from each of the four aquifers was created. Non-artesian wells were represented as blue circles, while artesian wells were illustrated as red circles. It should be noted that, for purposes of this thesis, any well that has at least one monitoring event where the DTW is less than or equal to $0.3 \mathrm{~m}$ would be denoted as artesian. For the first map (multi-aquifer map), the aquifer in which each well is screened was not taken into consideration. This allowed for a generalized overview of where artesian conditions occur and where they were sparse or absent regardless of the aquifers in which the wells were screened.

Four aquifer-specific maps were constructed, plotting artesian and non-artesian wells based upon the aquifer in which the wells were screened. Symbology for the four maps is identical to the multiple-aquifer map (non-artesian equals blue, 
artesian equals red). Additionally, within the four aquifer-specific maps, colored shaded regions were added. Yellow-shaded regions denote areas within the basin that contain wells that are frequently artesian (greater than $60 \%$ of measurements indicated artesian conditions). Green-shaded regions represent areas within the basin that have only gone artesian in direct response to 1998's substantial precipitation. Based upon precipitation data spanning 1995-2015 acquired from ACWD, the highest total rainfall year occurred in 1998.

Next, seasonal artesian/non-artesian maps were constructed individually for the Newark, Centerville, Fremont, and Deep aquifers, and placed within the "Supplemental File 1". These maps are constructed for each aquifer, consisting of one spring data map (March/April) and one fall data map (August/September) spanning 1995 to 2015. DTW values within the supplemental file are in ft. AMSL. Within each map, red circles represent artesian wells, while blue circles represent non-artesian wells. Once the plots were created, time-lapse animations were created compiling semi-annual monitoring events to better visualize temporal variations for each of the four alluvial systems. A month-long window for field measurement dates was used to create seasonal plots in ArcGIS. Many of the wells had multiple monitoring events within a month-long period depending on research projects carried out by ACWD. If there were multiple DTW measurements and there was a difference in head values between dates, then the highest potentiometric surface value was used.

Map sub-regions and Groups were created in order to more closely study 
artesian conditions in various portions of the basin that share similar hydraulic properties. Originally, 24 sub-regions were created, encompassing all artesian wells within the study area (Fig. 5). Further analysis of well-hydrographs created from each of the 24 sub-regions revealed that sub-groups 4 through 10 included wells containing erroneous reference point elevations or groundwater elevations creating false positives for artesian conditions. A total of 17 sub-regions were left containing artesian wells (sub-regions 1-3 and sub-regions 11-24). The remaining 17 subregions containing artesian wells were further analyzed (utilizing hydrograph DTW data) for similarities in hydraulic characteristics between neighboring groups and were condensed into five Groups (Groups A-E) presented in Figure 6. 


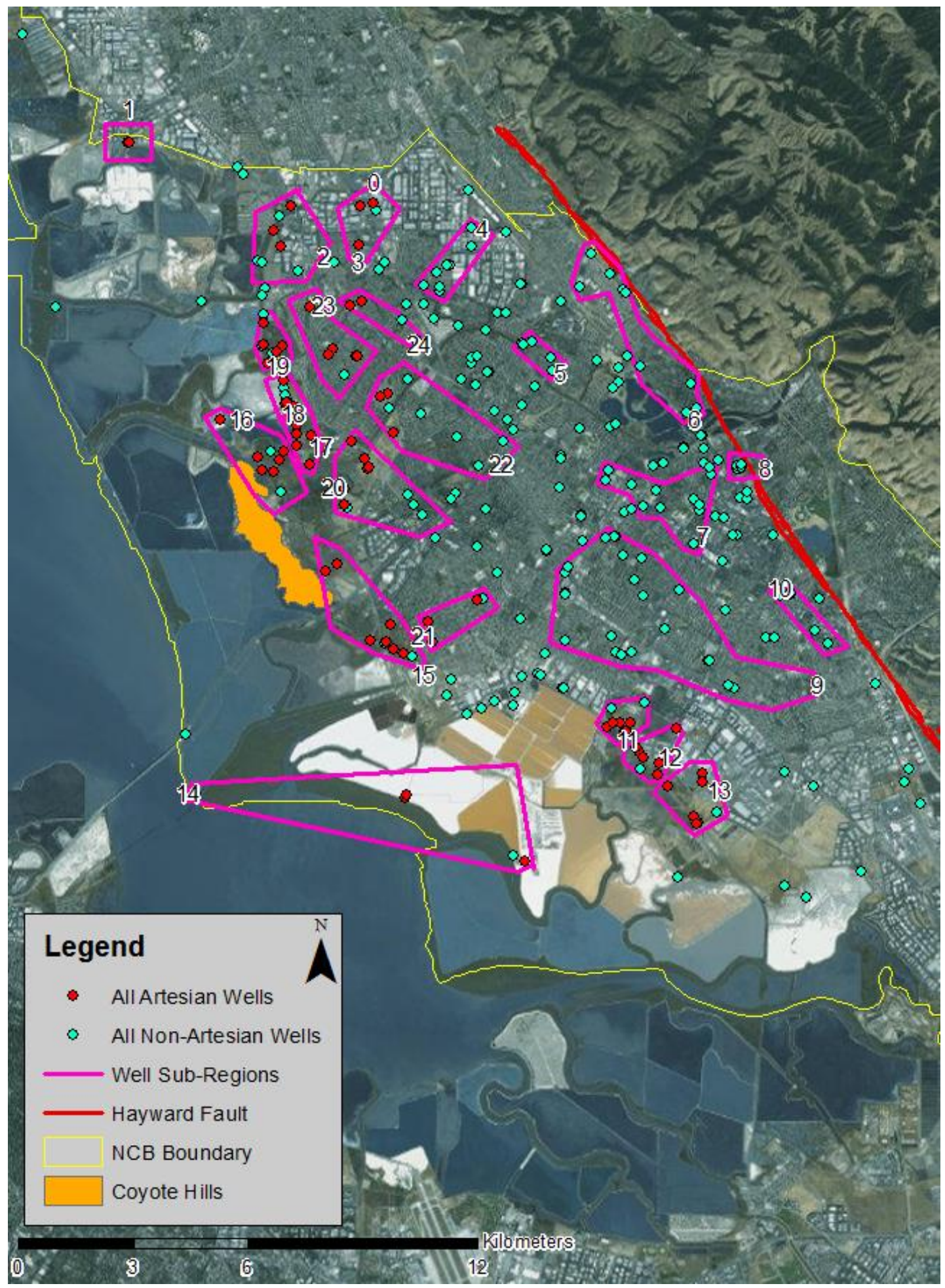

Figure 5. Map of twenty-four sub-regions. 


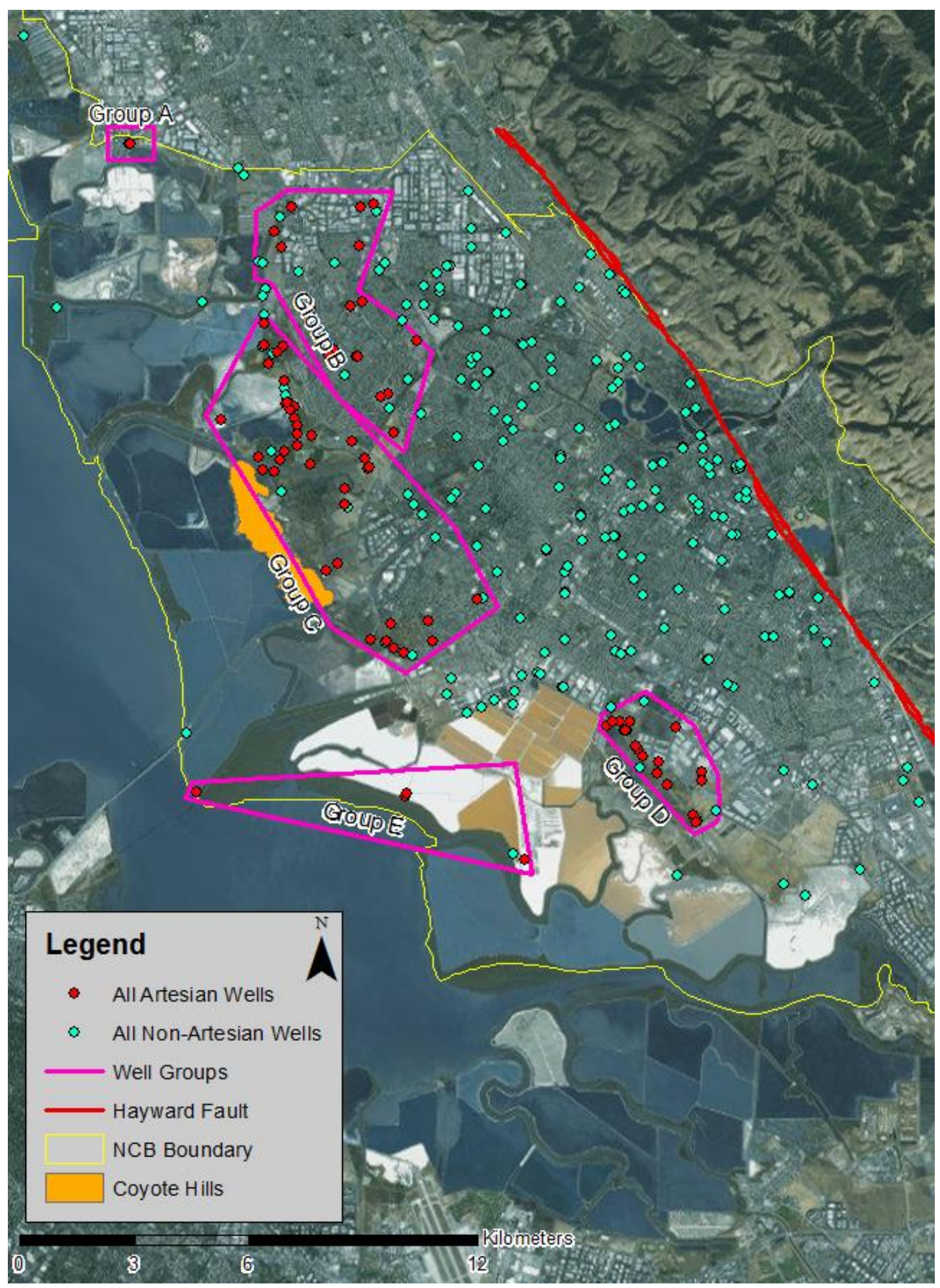

Figure 6. Map of five well Groups (A-E). 


\section{Hydrographs}

Hydrographs depict monitoring-well, water-level variations over time, providing a complete DTW history at each well's location, as opposed to limited semi-annual seasonal data. Originally, hydrographs were produced for all wells within the 24 sub-regions, and then a selection of representative hydrographs were produced for the five Groups (Groups A-E) spanning much of the basin. Focusing on Groups A through E, representative hydrographs were selected for each of the five Groups. A representative DTW plot consisted of hydrographs for both artesian and non-artesian wells within a specified Group with an attempt to include at least one artesian well from each aquifer, if possible. In addition, non-artesian wells for each aquifer were plotted by aquifer, if applicable, as a control well representing nonartesian conditions within the designated Group.

\section{Comparison with Inputs and Outputs}

In order to study the influence of precipitation on artesian conditions, regional precipitation data were acquired and analyzed. ACWD provided annual precipitation data ranging from the October 1994/September 1995 water year to the October 2014/September 2015 water year. Precipitation data were compared with the well hydrographs to visually track correlations between rainfall and artesian conditions for specific regions. Precipitation within the basin was plotted within each Group hydrograph (depicted by a dashed blue line with solid blue circles) as a means of correlating the influence that rainfall has on well DTW. 
The solid blue circles represent the annual total precipitation for the specified water year.

To evaluate the effect of pumping on artesian conditions within the NCB, pumping from the Mowry wellfield, from municipal, agricultural, and industrial wells, as well as from the ACWD's Aquifer Reclamation Program (ARP) wells (Fig. 3) was analyzed. For purposes of this paper, ARP wells are any wells that have been utilized by ACWD as aquifer recovery wells for the abatement of brackish water. Pumping can potentially cause depressions in the local potentiometric surface depending on the volume of water extracted. Pumping was taken into consideration when using groundwater elevations from monitoring wells near areas of highvolume pumping. The Mowry wellfield is comprised of nine production wells (Mowry 1 through Mowry 9) located to the southeast of the Quarry Lakes, just west of the Hayward fault within the BHF sub-basin. The ARP wells consist of a series of wells (Darvin 1 and 2, Cedar 1 and 2, Farwell, Lowry, Bellflower, and Willowood 1 and 2) used for the abatement of brackish groundwater within the basin due to the intrusion of saltwater from San Francisco Bay (ACWD, 2015). The Peralta-Tyson (PT) wellfield is not of concern for this studying. The PT wellfield is located just to the northeast of the Hayward fault within the AHF sub-basin. The Hayward fault creates an effective flow barrier that impedes the radius of influence produced from high production rates towards the BHF sub-basin. The Whipple and Nursery wells within the BHF sub-basin are ACWD standby wells which are only pumped for a short period annually and hence are not of concern due to the infrequency of their 
pumping. Lastly, the study area contains a privately owned high production well used by the Morton Salt Company located in the City of Fremont. Discharge from the Morton Salt well is monitored by the ACWD and is taken into consideration for this study. Daily pumping rates were recorded for ACWD's production wells. Pumping discharge was compared to fluctuations in DTW for regions that may be within a production well's radius of influence. Hydrographs constructed for regions within the basin containing monitoring wells that are near wellfields were fitted with a "Total NCB Pumping" line illustrated by a yellow colored dashed line. Solid yellow circles within the dashed yellow line denote the annual total volume in cubicmeters pumped for the specified water year. This permitted visual correlation between pumping and increases or decreases in DTW values. It should be noted that pumping data acquired from ACWD only goes back until 2000, resulting in a data gap from 1995 until 1999.

\section{Topography}

To study topographic influences on artesian conditions, two Digital Elevation Model (DEM) files were downloaded from the USGS's "The National Map" database. The study area is a low-relief, alluvial fan with surface elevations decreasing westward to the coastal margin of San Francisco Bay. Using ArcGIS, a hill-shade relief map was created from the two DEM files allowing for topographic features to be highlighted, more so than with a 2-D satellite image file. Additionally, artesian (red circles) and non-artesian (blue circles) wells were plotted on hill-shade maps by aquifer. Each well was labeled with its individual reference-point elevation. 
Most wells do not have a recorded surface elevation measurement, resulting in the wells' reference-point elevations acting as a surrogate value for the ground elevation. These maps permitted identification of artesian occurrences by elevation throughout the basin. 


\section{RESULTS}

\section{Spatial Distribution of Artesian Wells}

The spatial distribution of artesian wells for the NCB's four aquifers was interpreted from a multi-aquifer, well map created in ArcGIS (Fig. 7). The multiaquifer, well map delineates occurrences of artesian conditions towards the coastal margins, away from the Hayward fault. The presence of artesian conditions identified by the monitoring wells does not definitively delineate the exact location and extent of artesian conditions throughout the Fremont and Deep Aquifers. Artesian conditions may be present in portions of the Fremont and Deep Aquifers where wells are absent. More wells are completed within the Newark and Centerville Aquifers, providing clearer definition of hydraulic conditions for the basin's two shallowest aquifers. The Newark Aquifer contains the greatest number of monitoring wells, and the number of wells decreases through the Centerville, Deep, and the Fremont Aquifers, the latter containing the fewest wells completed solely in the Fremont Aquifer. 


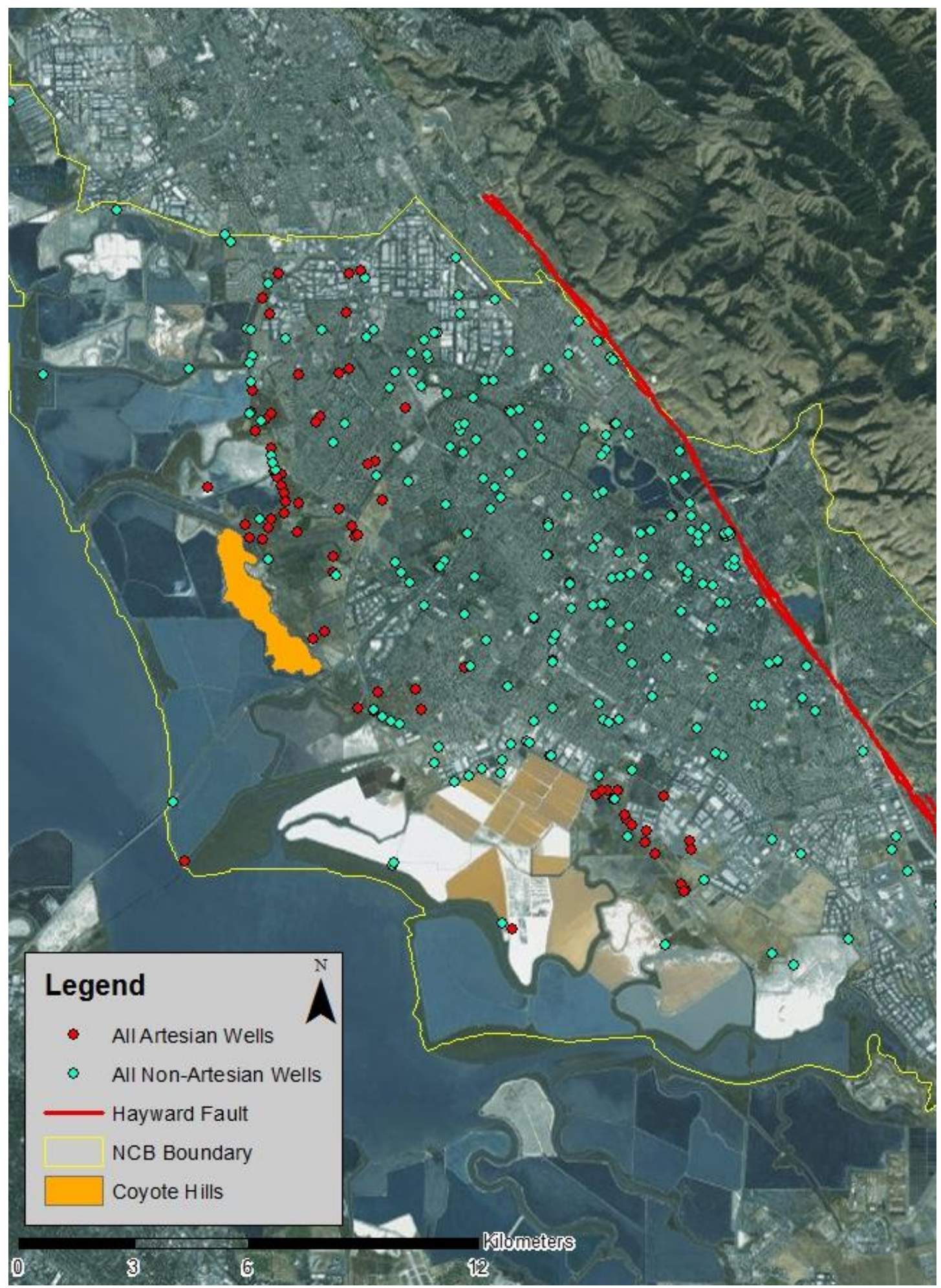

Figure 7. Well map presents wells that are individually screened within each of the four aquifers. 


\section{Newark Aquifer}

Figure 8 illustrates the spatial distribution of artesian wells within the Newark Aquifer, within the BHF sub-basin study area. A total of 156 wells screened within the Newark Aquifer were investigated. Of those 156 wells, 108 wells (blue circles) monitored between 1995 and 2015 have never gone artesian. The remaining 48 wells (red circles) have gone artesian at least once during a monitoring event conducted by ACWD. Generally, artesian wells occur down-gradient, in the distal extent of the fan to the west, away from the Hayward fault and forebay region. This trend follows topography and the westward declination of strata, with artesian conditions occurring more readily as the permeable bed dips westward towards the bay. The Newark Aquifer is comprised of an extensive permeable gravel and sand lithology, allowing for ease of transmission of groundwater down-gradient to the bay. The Newark Aquifer is completely confined except at the forebay, where there is a large, permeable area for recharge into the Newark and deeper aquifers at a high point within the BHF sub-basin. Additionally, seepage occurs across the Hayward fault from the AHF to the BHF, providing additional recharge to all BHF aquifers. Shaded green areas depict portions of the basin that have gone artesian as a direct response to 1998's high precipitation year. Shaded green areas within Figure 8 generally contain wells with higher TOC reference elevations. 


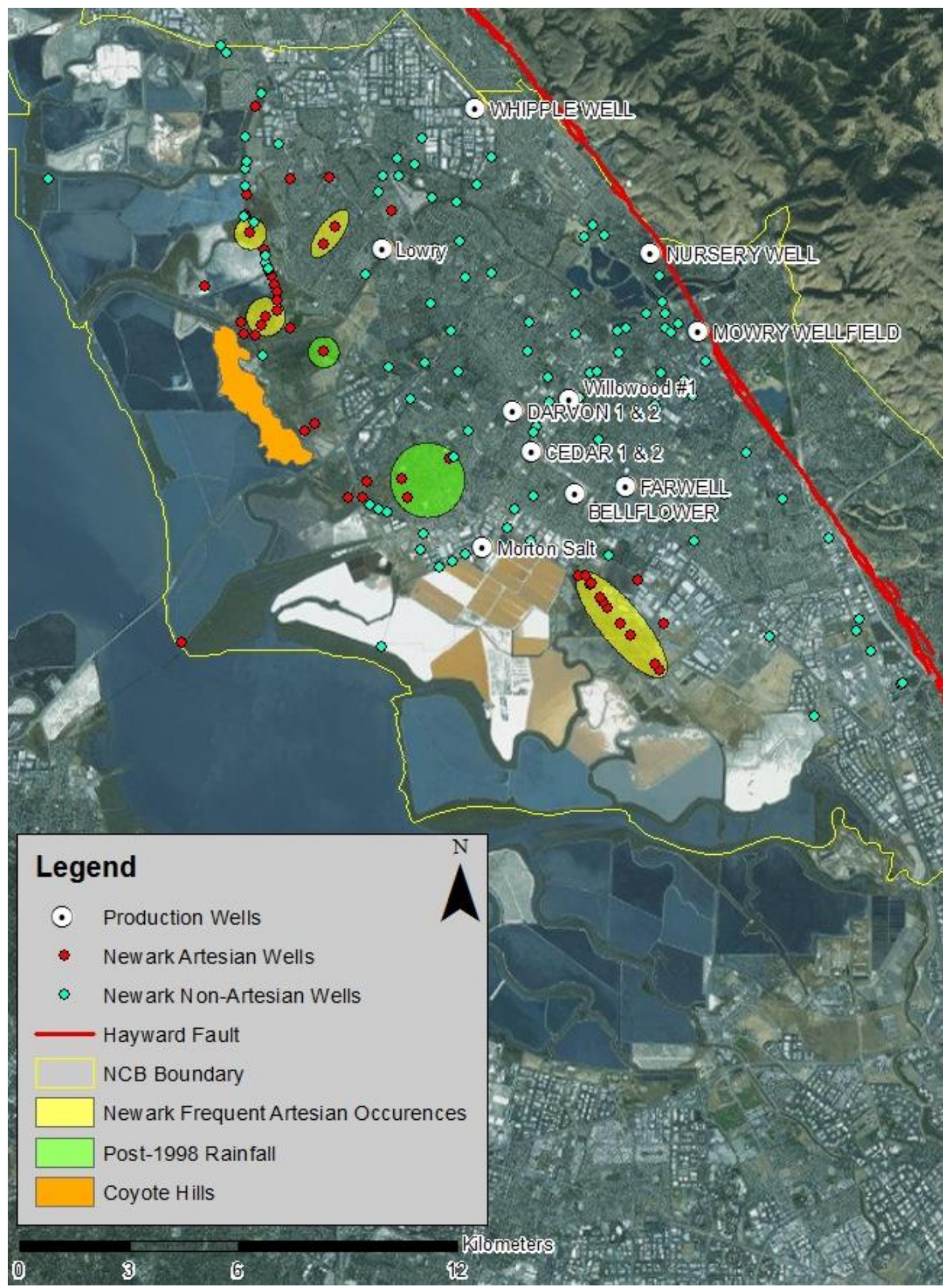

Figure 8. Newark Aquifer artesian and non-artesian events 
Wells occurring further inland within the basin toward higher surface elevations must have a greater input of water into the groundwater system to raise the potentiometric surface close to or above the ground surface. Throughout the NCB, ACWD limits artificial recharge as part of their basin management requirements. As a result, inland wells seldom have sufficient hydraulic heads to go artesian. In contrast, wells encompassed by yellow-shaded areas represent wells that have gone artesian during greater than $60 \%$ of the well's monitoring events from 1995 to 2015.

The eastern-most occurrences of artesian wells paralleling the Hayward fault provide an appropriate approximation of the furthest eastern extent of artesian conditions. Monitoring wells in the southern-most portion of the NCB are sparse, and the absence of artesian wells made it difficult to delineate artesian conditions in the southern-most portion of the Newark Aquifer. Monitoring wells in the northern part of the NCB are sparse with the northern-most artesian well, providing limited data of artesian occurrences near the northern border.

Temporal variations in the distribution of artesian conditions are presented by seasonal time-lapse maps (Supplemental File 1). Generally, artesian wells occur more frequently during spring months owing to higher winter precipitation, as would be expected. Table 1 provides monitoring statistics for seasonal monitoring events from 1995 to 2015 for the Newark Aquifer. 
Table 1. Newark Aquifer well-network monitoring statistics.

\begin{tabular}{|c|c|c|c|c|c|c|c|}
\hline Season & Year & $\begin{array}{c}\text { Total \# of } \\
\text { Artesian } \\
\text { Wells }\end{array}$ & $\begin{array}{c}\text { Total \# of } \\
\text { Wells } \\
\text { Monitored }\end{array}$ & Season & Year & $\begin{array}{c}\text { Total \# of } \\
\text { Artesian } \\
\text { Wells }\end{array}$ & $\begin{array}{c}\text { Total \# of } \\
\text { Wells } \\
\text { Monitored }\end{array}$ \\
\hline Spring & 1995 & 4 & 92 & Fall & 1995 & 4 & 107 \\
\hline Spring & 1996 & 5 & 50 & Fall & 1996 & 2 & 86 \\
\hline Spring & 1997 & 7 & 102 & Fall & 1997 & 0 & 50 \\
\hline Spring & 1998 & 21 & 105 & Fall & 1998 & 21 & 106 \\
\hline Spring & 1999 & 37 & 118 & Fall & 1999 & 23 & 102 \\
\hline Spring & 2000 & 2 & 10 & Fall & 2000 & 9 & 41 \\
\hline Spring & 2001 & 4 & 20 & Fall & 2001 & 12 & 98 \\
\hline Spring & 2002 & 3 & 22 & Fall & 2002 & 10 & 80 \\
\hline Spring & 2003 & 7 & 80 & Fall & 2003 & 5 & 55 \\
\hline Spring & 2004 & 5 & 42 & Fall & 2004 & 5 & 80 \\
\hline Spring & 2005 & 14 & 97 & Fall & 2005 & 10 & 83 \\
\hline Spring & 2006 & 12 & 93 & Fall & 2006 & 6 & 66 \\
\hline Spring & 2007 & 10 & 104 & Fall & 2007 & 5 & 43 \\
\hline Spring & 2008 & 12 & 102 & Fall & 2008 & 7 & 102 \\
\hline Spring & 2009 & 11 & 102 & Fall & 2009 & 7 & 102 \\
\hline Spring & 2010 & 17 & 102 & Fall & 2010 & 9 & 102 \\
\hline Spring & 2011 & 15 & 87 & Fall & 2011 & 12 & 100 \\
\hline Spring & 2012 & 6 & 70 & Fall & 2012 & 4 & 102 \\
\hline Spring & 2013 & 3 & 91 & Fall & 2013 & 0 & 98 \\
\hline Spring & 2014 & 0 & 100 & Fall & 2014 & 0 & 104 \\
\hline Spring & 2015 & 5 & 100 & Fall & 2015 & 0 & 12 \\
\hline
\end{tabular}

It is important to note that during years when artesian conditions occurred more frequently in the fall than in the spring (i.e., 2000, 2001, and 2002), there were a substantially greater number of wells measured for those fall monitoring dates than for spring. Differences in sampling frequency can also be observed for spring months. This intermittent monitoring of wells throughout the well network can be seen throughout the Centerville, Fremont, and Deep. 


\section{Centerville Aquifer}

Within the Centerville Aquifer (Fig. 9), a total of 120 wells (completed solely in the Centerville or completed in both the Centerville and the Fremont) were studied to identify the spatial distribution of artesian conditions. Of the 120 wells, 90 of them (blue circles) have never gone artesian between 1995 and 2015 during monitoring events, and a total of 30 (red circles) have gone artesian at least once. The Centerville Aquifer had a similar spatial distribution of artesian wells as seen in the Newark Aquifer. Similarities are inferred due to the affinity of artesian wells to occur away from the Hayward fault and forebay region of the BHF sub-basin and down-gradient at lower topographic elevations. Analogous to the map for the Newark Aquifer, green-shaded zones (indicating artesian conditions related to the 1998 high-precipitation year) within the Centerville Aquifer generally included artesian wells that were installed further inland, up-gradient toward topographically higher elevations in comparison to other artesian wells. There are two isolated areas containing artesian wells that were frequently (greater than $60 \%$ of monitoring events) artesian, both toward the distal extent of the fan, adjacent to the salt ponds and bay. The lower reference point elevations allow wells within the yellow shaded regions to remain artesian nearly perennially throughout the study period. 


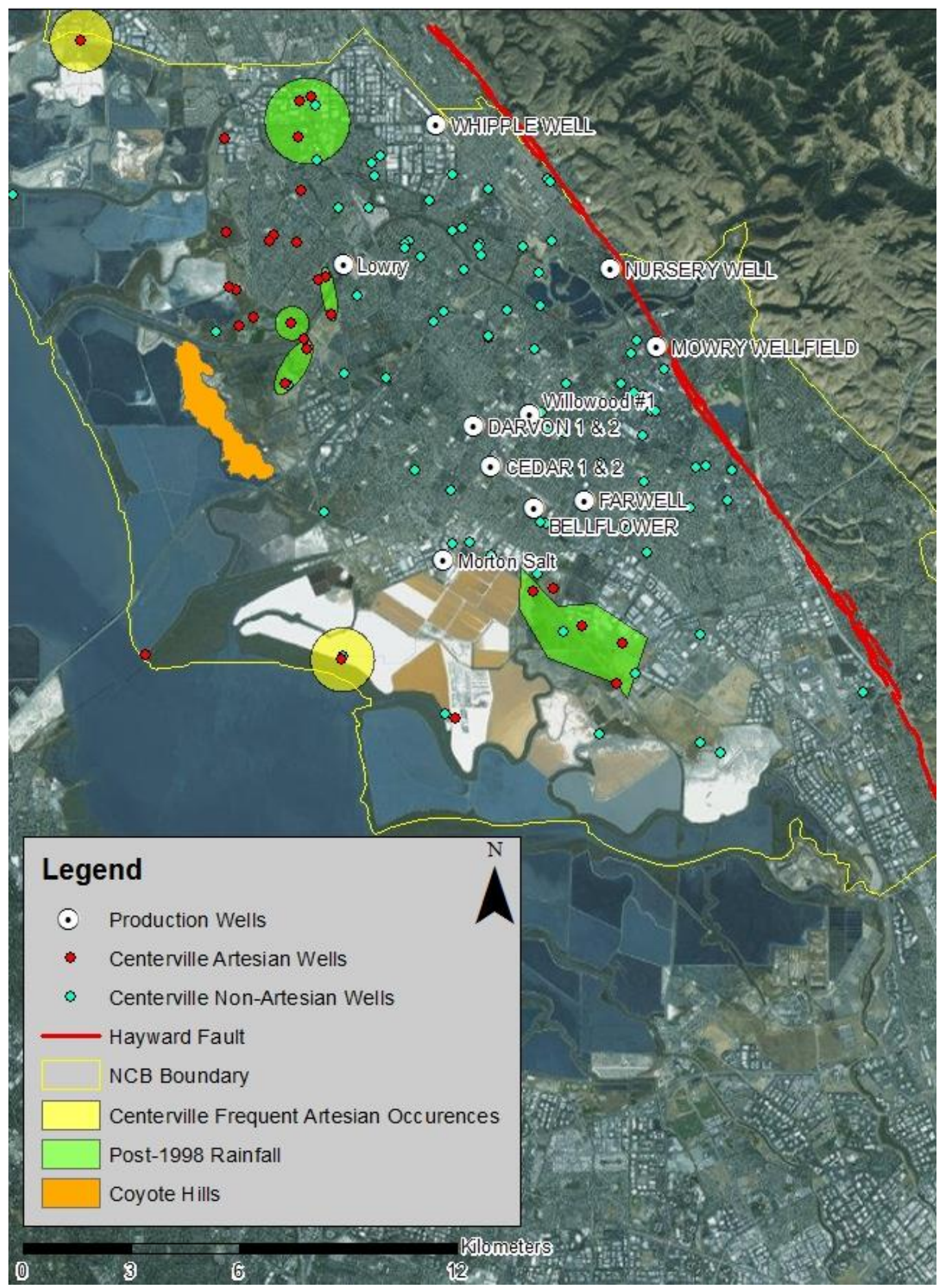

Figure 9. Centerville Aquifer artesian and non-artesian events. 
A large number of artesian wells installed in the Centerville Aquifer can be observed to the east and northeast of the Coyote Hills. The northern-most wells within the study area are artesian, so that the northern limit of artesian conditions is undefined. Longitudinally north to south, artesian conditions appear to be well defined to the east, paralleling the Hayward fault, approximately halfway between the fault and the shoreline. Artesian wells to the south occur within or in close proximity to the salt ponds. The spatial limit of artesian conditions in the southern portion of the basin can be approximated due to the presence of non-artesian wells to the south.

Similar to the Newark Aquifer, temporal influence on the occurrence and spatial distribution of artesian conditions within the basin is important. Supplemental File 1 illustrates a time-lapse animation depicting seasonal influences on artesian wells throughout the Centerville Aquifer. The time-lapse maps exhibit a distinct trend of artesian conditions occurring more frequently in the spring than in the fall. Unfortunately, Table 2 presented below demonstrates variability in the number of monitoring events each well has undergone for the Centerville well network for each fall and spring monitoring period.

\section{Fremont Aquifer}

The Fremont Aquifer had 27 wells with groundwater-elevation data between 1995 and 2015. Of those 27 wells, only one well had gone artesian. The location of the artesian well shown on Figure 10 is approximately $5.5 \mathrm{~km}$ southeast of the Coyote Hills and approximately $0.5 \mathrm{~km}$ inland from the San Francisco Bay. 
Table 2. Centerville Aquifer well network monitoring statistics.

\begin{tabular}{cccc|cccc}
\hline \hline Season & Year & $\begin{array}{c}\text { Artesian } \\
\text { Wells }\end{array}$ & $\begin{array}{c}\text { Wells } \\
\text { Monitored }\end{array}$ & Season & Year & $\begin{array}{c}\text { Total \# of } \\
\text { Artesian }\end{array}$ & $\begin{array}{c}\text { Total \# of } \\
\text { Wells }\end{array}$ \\
& & & & Wells & Monitored \\
\hline Spring & 1995 & 0 & 76 & Fall & 1995 & 0 & 75 \\
Spring & 1996 & 0 & 31 & Fall & 1996 & 0 & 68 \\
Spring & 1997 & 0 & 53 & Fall & 1997 & 0 & 37 \\
Spring & 1998 & 14 & 62 & Fall & 1998 & 0 & 56 \\
Spring & 1999 & 16 & 65 & Fall & 1999 & 1 & 61 \\
Spring & 2000 & 2 & 8 & Fall & 2000 & 1 & 37 \\
Spring & 2001 & 5 & 21 & Fall & 2001 & 2 & 75 \\
Spring & 2002 & 2 & 15 & Fall & 2002 & 0 & 65 \\
Spring & 2003 & 4 & 65 & Fall & 2003 & 1 & 27 \\
Spring & 2004 & 2 & 30 & Fall & 2004 & 1 & 62 \\
Spring & 2005 & 5 & 60 & Fall & 2005 & 1 & 45 \\
Spring & 2006 & 2 & 68 & Fall & 2006 & 1 & 48 \\
Spring & 2007 & 2 & 73 & Fall & 2007 & 2 & 26 \\
Spring & 2008 & 2 & 68 & Fall & 2008 & 2 & 26 \\
Spring & 2009 & 6 & 71 & Fall & 2009 & 1 & 71 \\
Spring & 2010 & 5 & 70 & Fall & 2010 & 2 & 67 \\
Spring & 2011 & 2 & 57 & Fall & 2011 & 2 & 63 \\
Spring & 2012 & 3 & 49 & Fall & 2012 & 3 & 65 \\
Spring & 2013 & 3 & 58 & Fall & 2013 & 0 & 66 \\
Spring & 2014 & 1 & 24 & Fall & 2014 & 0 & 68 \\
Spring & 2015 & 1 & 71 & Fall & 2015 & 0 & 12 \\
\hline
\end{tabular}

Due to the low well-density within the Fremont Aquifer and the lack of artesian wells, artesian conditions are determined to be uncommon for this aquifer based upon available data. The one artesian well within the Fremont Aquifer appears to be uninfluenced by temporal influences due to the well displaying artesian conditions nearly perennially from spring 2007 to spring 2015 . The well has been monitored a total of 29 times during various seasons (Supplemental File 1) and has been measured as artesian 27 of those times, placing the well within the maps yellow shaded region. 


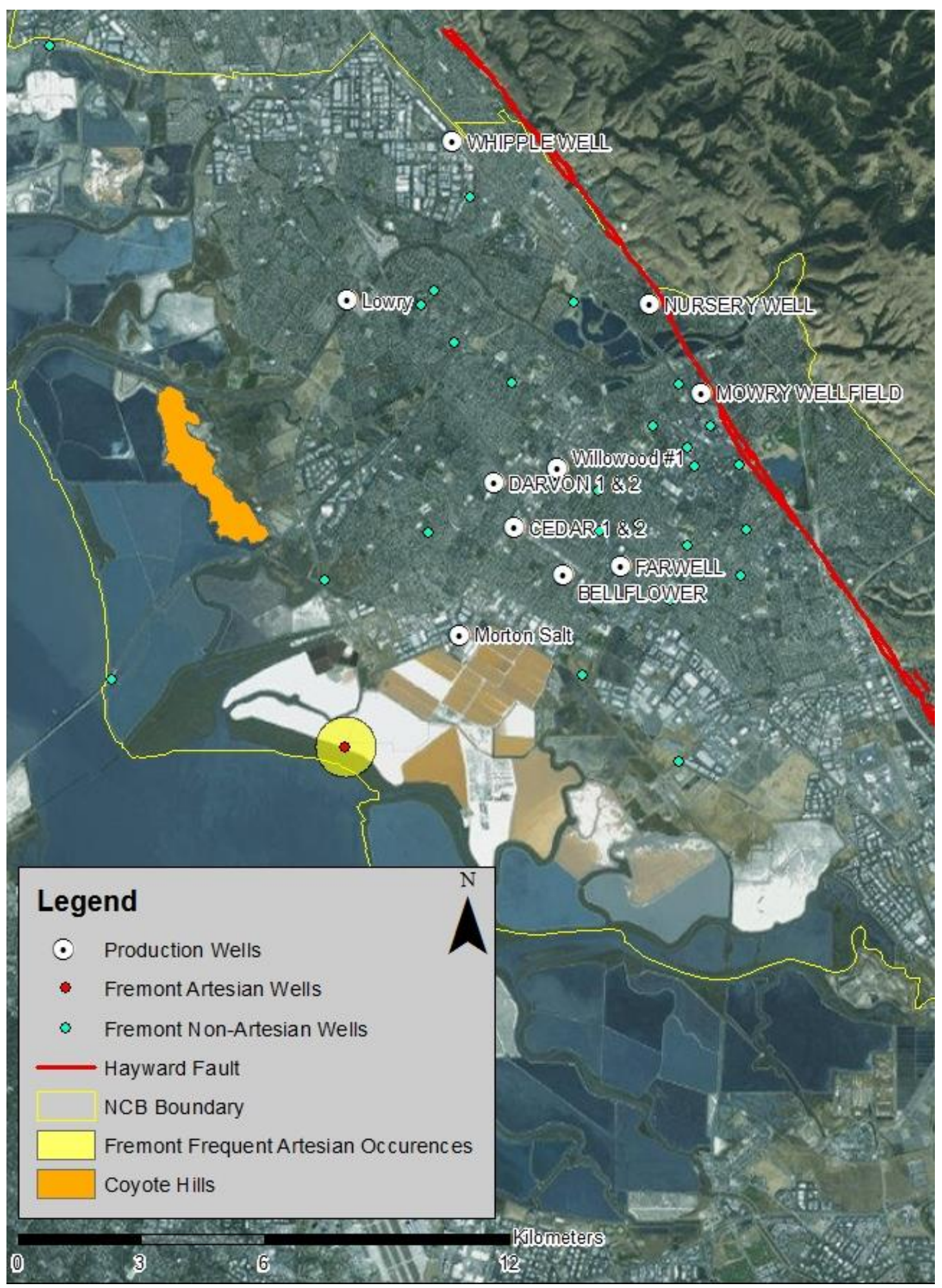

Figure 10. Fremont Aquifer artesian and non-artesian events 


\section{Deep Aquifer}

Lastly, the Deep Aquifer had 46 wells that had groundwater-elevation data ranging from 1995 to 2015. Out of the 46 wells, 39 wells (blue circles) had not gone artesian, and a total of seven wells (red circles) had gone artesian at least once. It should be noted that there are three wells located within the yellow shaded region within Figure 11 potentially appearing as one well owing to their close proximity to one another. Figure 11 displays a consistent trend in artesian wells occurring at lower surface elevations close to the San Francisco Bay. Well density for the Deep Aquifer is much lower than the Newark and Centerville Aquifers, but spatially artesian conditions occur further west towards the bay than in the shallower aquifers. Accurate definition of the spatial extent of artesian conditions in the Deep Aquifer is difficult due to low well-density.

Temporal influences on artesian conditions within the Deep Aquifer are difficult to interpret, resulting from variable monitoring of the Deep Aquifer's well network. Artesian conditions occur for the seven artesian wells in both fall and spring monitoring events. Unfortunately, the time-lapse maps created for the Deep Aquifer (Supplemental File 1) display various wells that are artesian during a fall monitoring event but are not monitored during the following spring. 


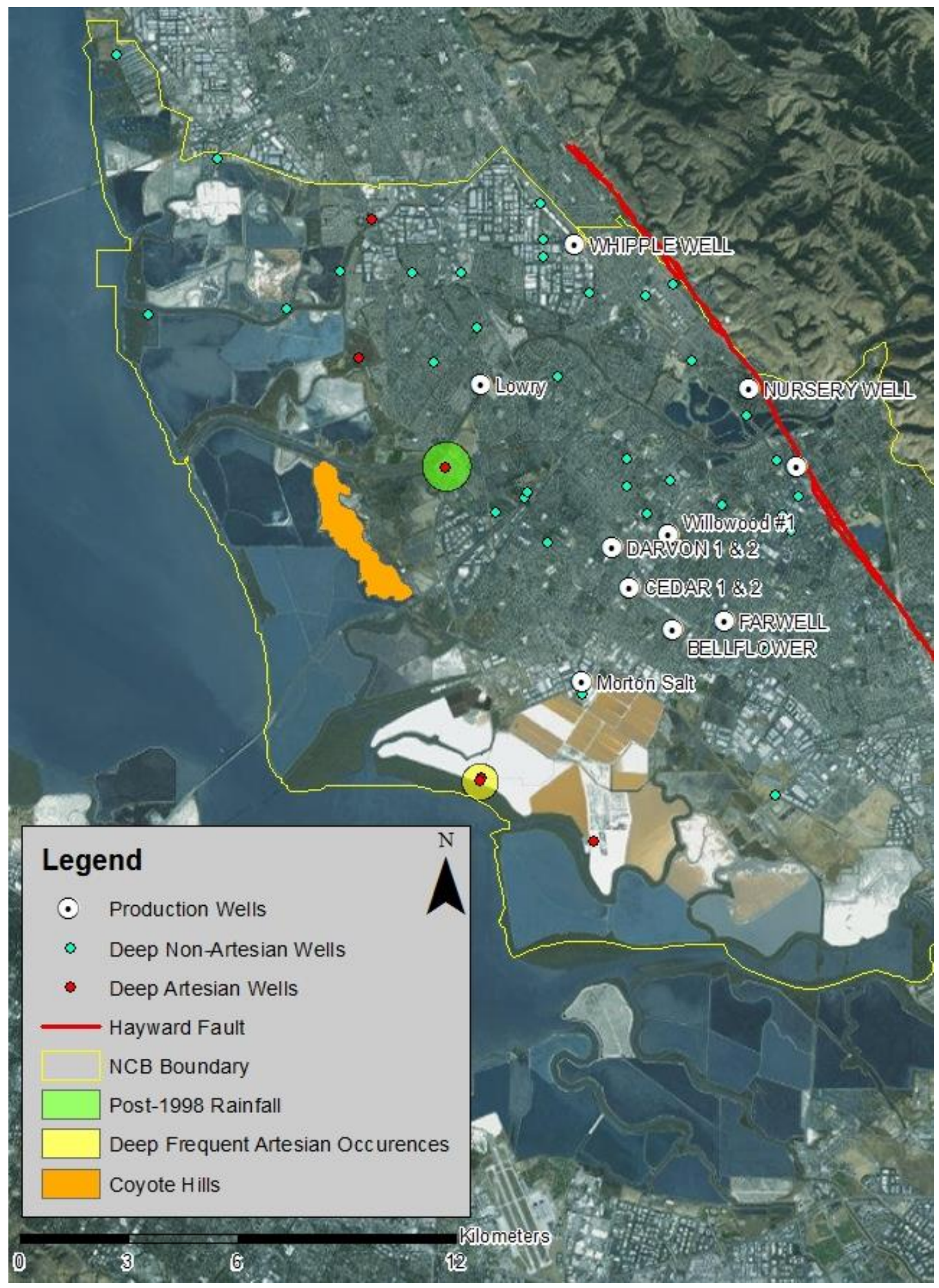

Figure 11. Deep Aquifer artesian and non-artesian events. 


\section{Topography}

The NCB's topographic signature results from the formation of the alluvial fan by the Alameda Creek. The fan forms a gently sloping, low relief topography that spreads out westward towards San Francisco Bay. Figures 12 through 15 display reference-point elevations, by aquifer, for each artesian (red dot) and non-artesian (blue dot) well. The reference point elevations reflect the gently-sloping topography of the basin as well as the surface elevations where artesian conditions exist. Spatially, all artesian wells within each of the four alluvial aquifers occur towards the west, down-gradient from the fan's apex. These wells are within regions where reference point elevations are less than 5.2 MASL, but more frequently at reference point elevations lower than 3.0 MASL. These two characteristic elevations are depicted within Figure 16, illustrated by the sandcolored contour lines. In the eastern portion of the BHF sub-basin, reference point elevations range from approximately 23 to 20 MASL in the vicinity of the Hayward fault. Reference point elevations measured at monitoring wells towards the distal extent of the fan, just east of the salt ponds, had elevation values ranging from approximately 1 to 4 MASL.

With the basin's resulting low topographic relief, localized natural features such as depressions or knolls, or even anthropogenic features such as levees and road cuts, can potentially lower or raise the reference point elevation of a monitoring well in a localized area. 


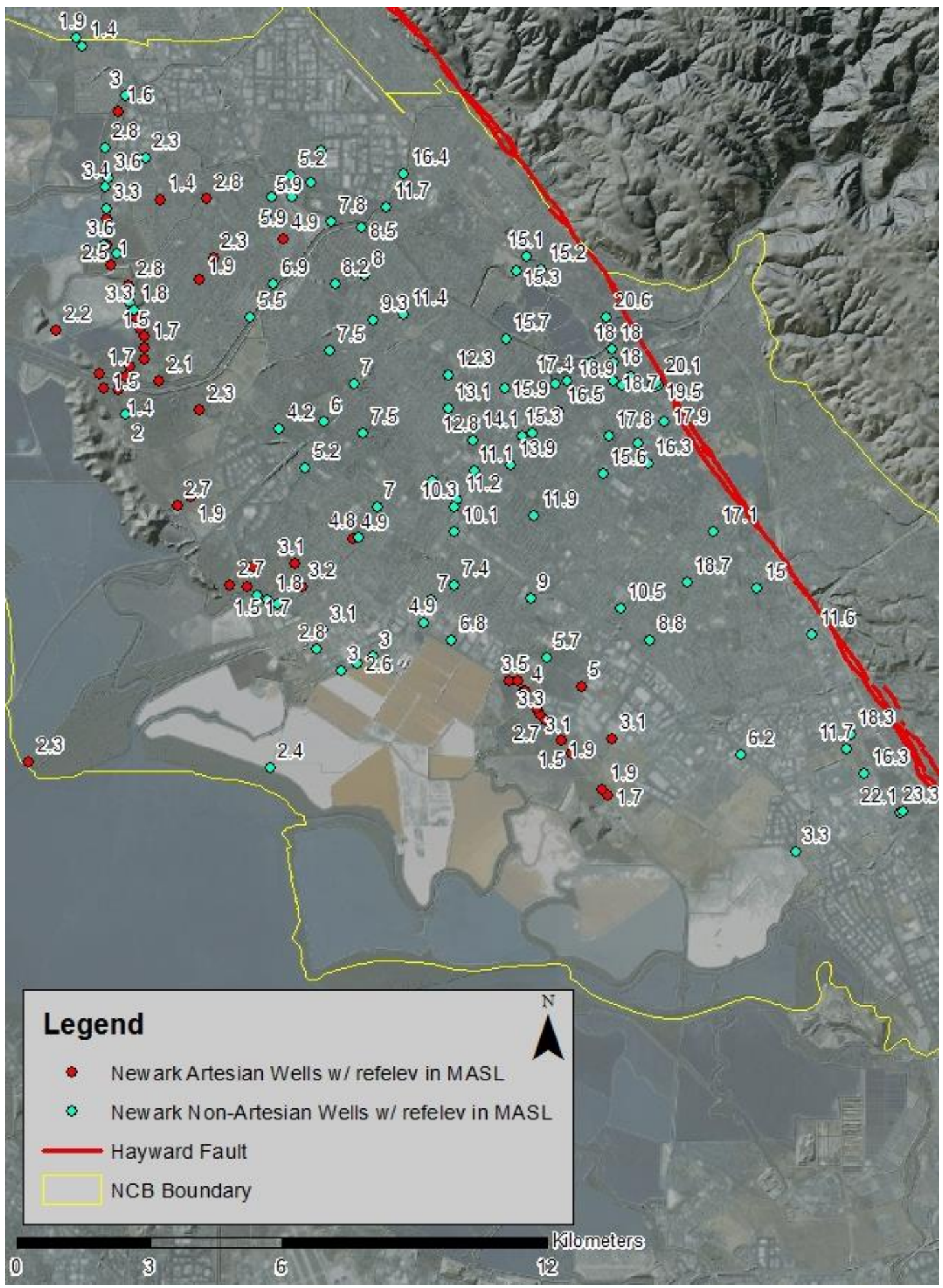

Figure 12. Newark Aquifer wells with labeled TOC reference elevations measured in MASL. 


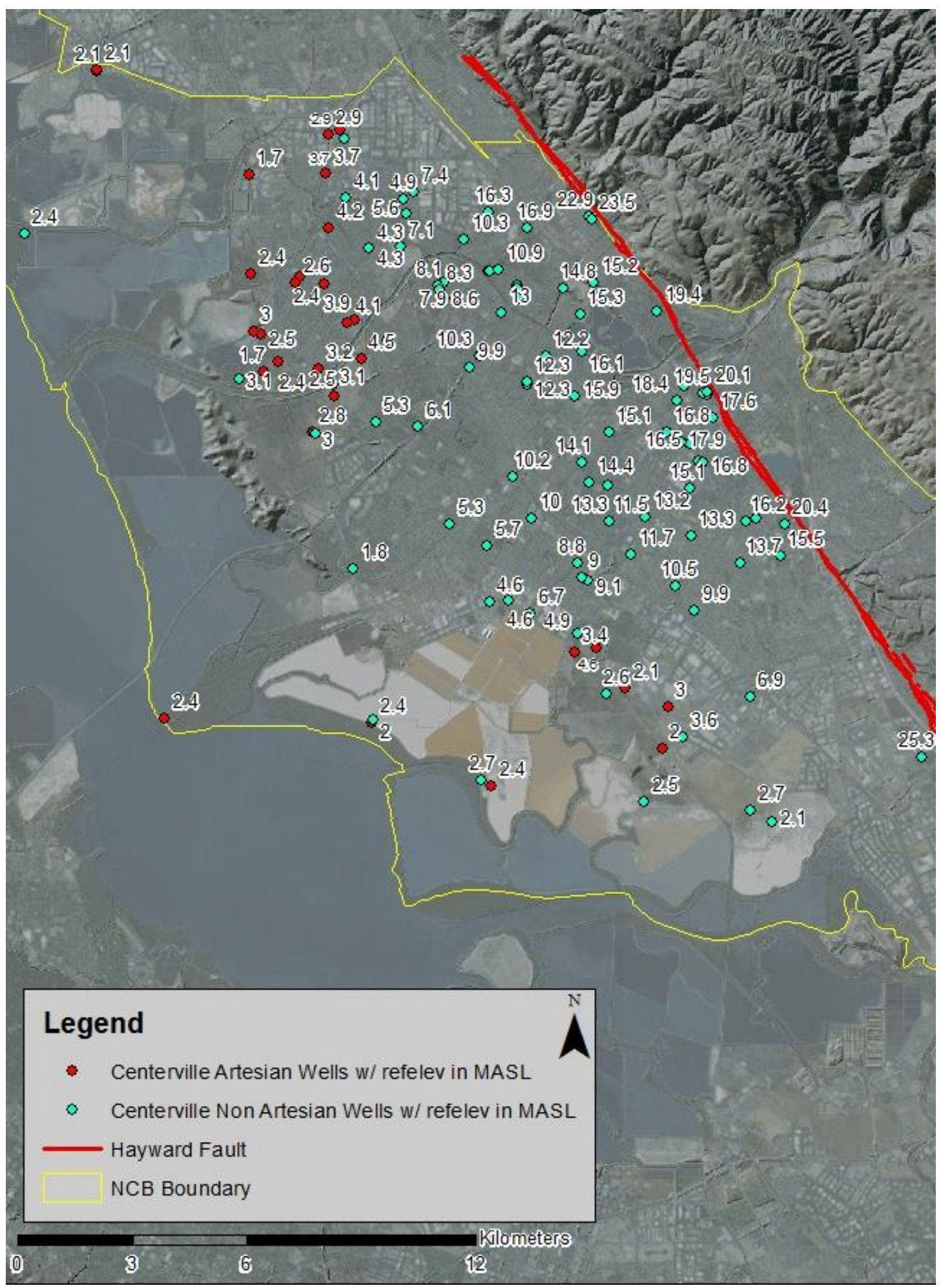

Figure 13. Centerville Aquifer wells with labeled TOC reference elevations measured in MASL. 


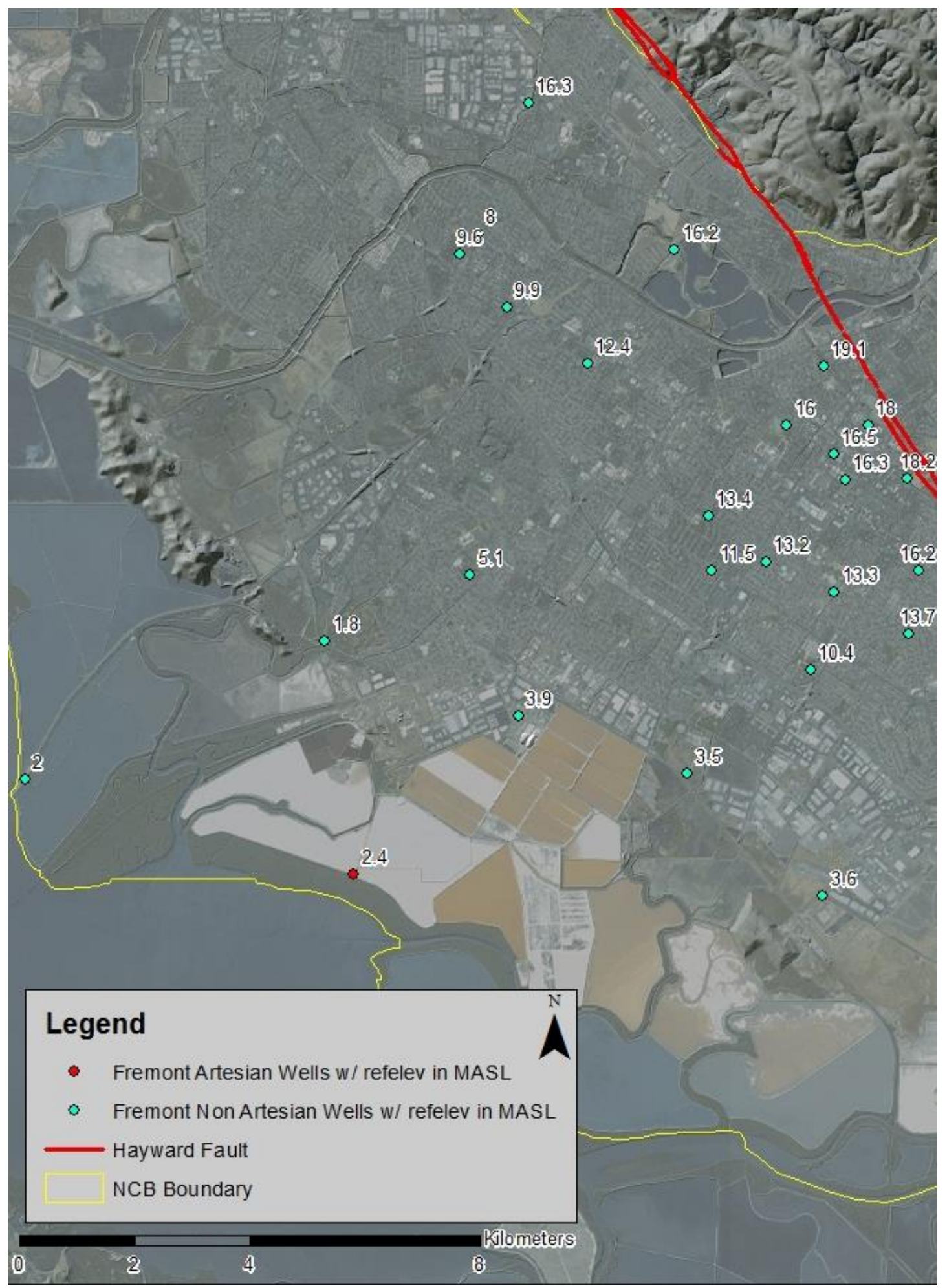

Figure 14. Fremont Aquifer wells with labeled TOC reference elevations measured in MASL. 


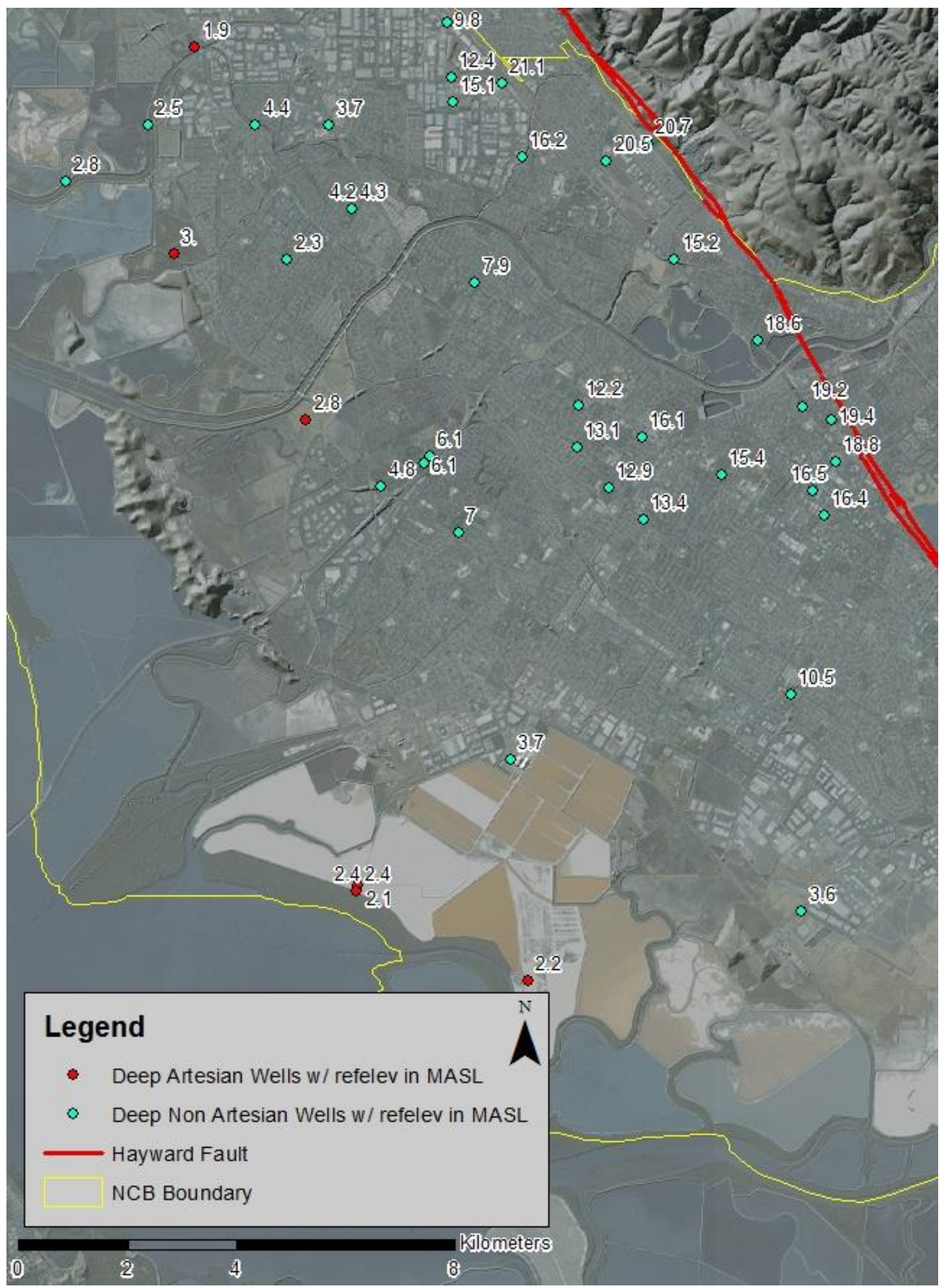

Figure 15. Deep Aquifer wells with labeled TOC reference elevations measured in MASL. 


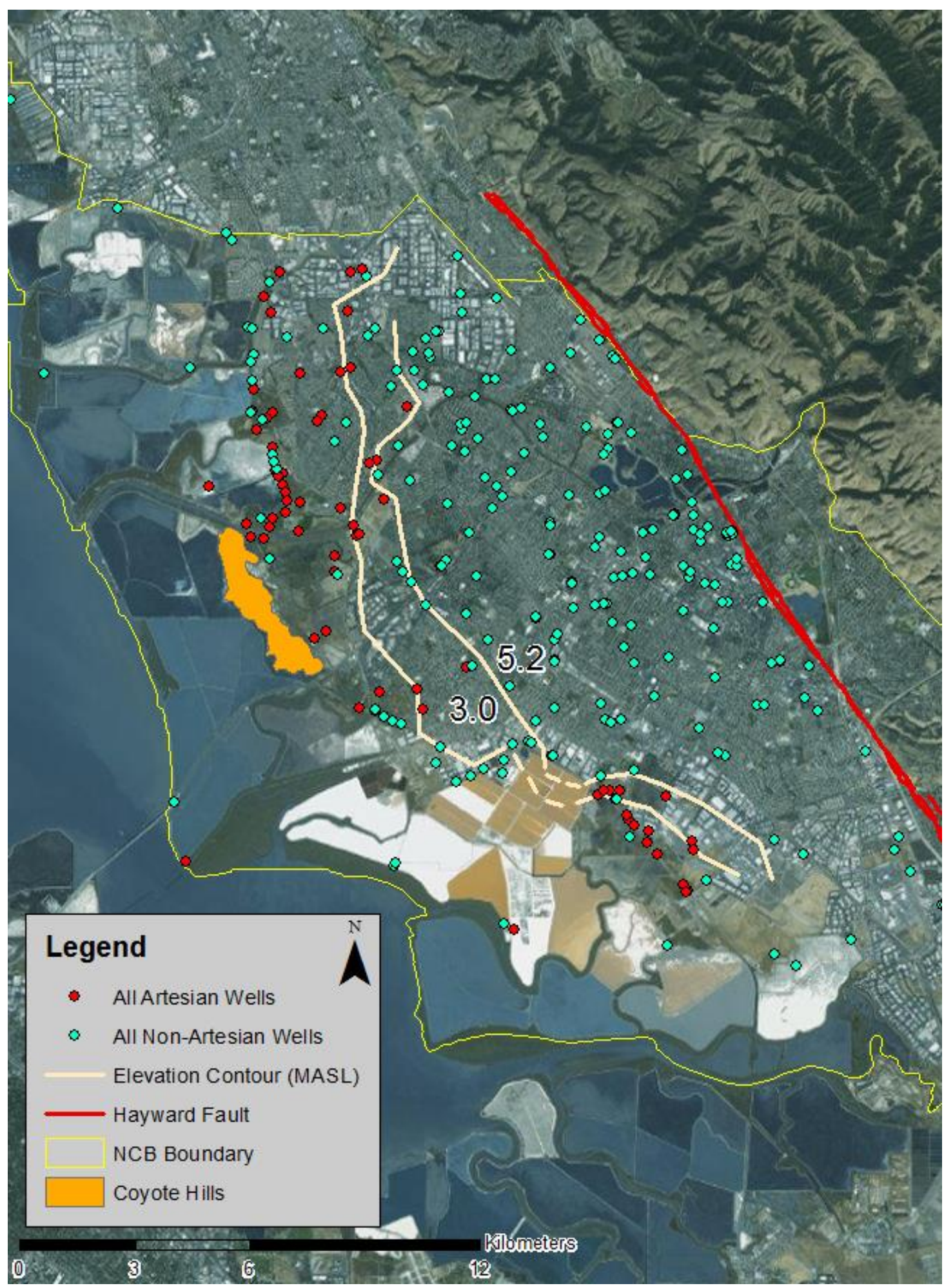

Figure 16. NCB containing all aquifer wells with 3.0 and 5.2 MASL TOC reference elevation contour lines. 
A higher reference point elevation at a well in a localized area may bring the TOC just above a given aquifer's potentiometric surface, creating a non-artesian well adjacent to an artesian well with a lower reference point elevation.

Wells were studied within all four aquifers separately to determine if topography could explain the occurrence of adjacent artesian and non-artesian wells screened within the same water-bearing zone. Unfortunately, the Fremont and Deep Aquifers lacked any neighboring artesian and non-artesian wells so such an evaluation could not be made for those two aquifers. Wells were considered adjacent if there was a distance of no more than $400 \mathrm{~m}$ separating both wells. Within the Newark Aquifer, focusing on the eastern border of the salt ponds stretching north and east, a number of adjacent artesian and non-artesian wells were observed. Towards the northern-most portion of Group C, an artesian well is located approximately $248 \mathrm{~m}$ from an adjacent non-artesian well. Table 3 contains technical data for the two adjacent wells. The change in hydraulic head over $248 \mathrm{~m}$ is only approximately $0.1 \mathrm{~m}$, for the same monitoring date. The significant difference in TOC reference point elevations between both adjacent wells, regardless of comparable water table elevations between the two points, caused one well (4S/2W-16C012) to go artesian (lower TOC reference elevation) while the neighboring well (4S/2W-16C011) did not (higher TOC reference elevation). This can be attributable to topographic variations between the locations of both wells. 
Table 3. Newark Aquifer adjacent wells.

\begin{tabular}{cccccc}
\hline \hline $\begin{array}{c}\text { Well } \\
\text { Condition }\end{array}$ & Well ID & $\begin{array}{c}\text { TOC Ref } \\
\text { Elevation } \\
\text { (MASL) }\end{array}$ & $\begin{array}{c}\text { DTW } \\
\text { (M) }\end{array}$ & $\begin{array}{c}\text { Groundwater } \\
\text { Elevation } \\
\text { (MASL) }\end{array}$ & $\begin{array}{c}\text { Monitoring } \\
\text { Date }\end{array}$ \\
\hline $\begin{array}{c}\text { Artesian } \\
\text { Well } \\
\text { Non- } \\
\text { artesian } \\
\text { Wells }\end{array}$ & $4 \mathrm{~S} / 2 \mathrm{~W}-16 \mathrm{C} 012$ & 1.54 & 0.30 & 1.24 & $3 / 19 / 1999$ \\
\hline
\end{tabular}

Another example of topographic influence on adjacent artesian and non-artesian wells can be observed for the Centerville Aquifer within the northeastern most portion of Group G. Table 4 contains technical data for the two adjacent wells within the Centerville Aquifer. Between both wells, hydraulic head varied by $0.27 \mathrm{~m}$ for the $03 / 19 / 1998$ monitoring event, and $0.24 \mathrm{~m}$ for the $03 / 15 / 1999$ monitoring event over a separating distance of approximately $332 \mathrm{~m}$. Owing to slight topographic differences between both wells, the non-artesian well's TOC reference point elevation was above the Centerville Aquifer's potentiometric surface within Group G. The result of a lower TOC reference elevation caused 4S/2W-03K001 to go artesian, while 4S/2W-03R003 remained non-artesian even during a raised-watertable event. Approximately 40\% of identified artesian and non-artesian adjacent (no more than $400 \mathrm{~m}$ apart) wells (screened within same aquifer) throughout the Newark and Centerville contained considerable differences in reference point elevations, owing to local topographic differences. 
Table 4. Centerville Aquifer adjacent wells.

\begin{tabular}{|c|c|c|c|c|c|}
\hline $\begin{array}{c}\text { Well } \\
\text { Condition }\end{array}$ & Well ID & $\begin{array}{c}\text { TOC Ref } \\
\text { Elevation } \\
\text { (MASL) }\end{array}$ & $\begin{array}{c}\text { DTW } \\
\text { (m) }\end{array}$ & $\begin{array}{l}\text { Groundwater } \\
\text { Elevation } \\
\text { (MASL) }\end{array}$ & $\begin{array}{c}\text { Monitoring } \\
\text { Date }\end{array}$ \\
\hline Artesian & & & 0.15 & 2.71 & $3 / 19 /$ \\
\hline $\begin{array}{l}\text { Well } \\
\text { Non- }\end{array}$ & 4S/2W-03K001 & 9.87 & 0 & 87 & $3 / 15 / 1999$ \\
\hline Artesiar & & & 1.22 & 2.44 & $3 / 19 / 1998$ \\
\hline Well & 4S/2W-03R003 & 3.66 & 0.55 & 3.11 & $3 / 15 / 1999$ \\
\hline
\end{tabular}

\section{Hydrographs}

To study the variability in artesian conditions with time, well groupings were created to illustrate similar hydraulic responses by region. Groups A through E, shown on Figure 6, were created by studying well hydrographs (organized for all wells by sub-region in Appendix A).

Hydrographs were generated for each Group to look at variations in artesian conditions over time for different regions of the basin. To study inflow effects on artesian conditions within the basin, rainfall data were plotted on each hydrograph grouping to compare seasonal influences on DTW variations for each well.

Seasonality of precipitation from 1995 to 2015 is quite consistent with the highest rainfall months seen during December to February and the lowest observed during July to September. In addition, pumping data were added for Group D which is located near a region of major pumping. 


\section{Group A.}

Group A, located in the northern-most portion of the study area, contains a total of three wells clustered within close proximity (less than $6.1 \mathrm{~m}$ from one another). Wells 4S/2W-05G004 and 4S/2W-05G005 are both screened within the Centerville Aquifer, and 4S/2W-05G001 is screened within the Fremont Aquifer. Studying the hydrographs presented in Figure 17, the precipitation line matches up well with trends displayed by the three wells. Well 4S/2W-05G004 has been monitored from 2005 to 2015 and has only gone artesian six times. The Fremont well has been monitored consistently from 2005 to 2015 and has never gone artesian. Both Centerville wells have been monitored during the same monitoring period and only one well has been perennially artesian from 2005 until 2011. There is decline in water level for each well post 2011 with the beginning of the drought. Observing the hydrographs, there appears to be a significant downward hydraulic gradient from the shallower Centerville well (4S/2W-05G005, screened 41-52 mbgs) to the deeper (4S/2W-05G004, screened 59-66 mbgs) Centerville well and a continued consistent downward gradient to the even deeper Fremont well. 


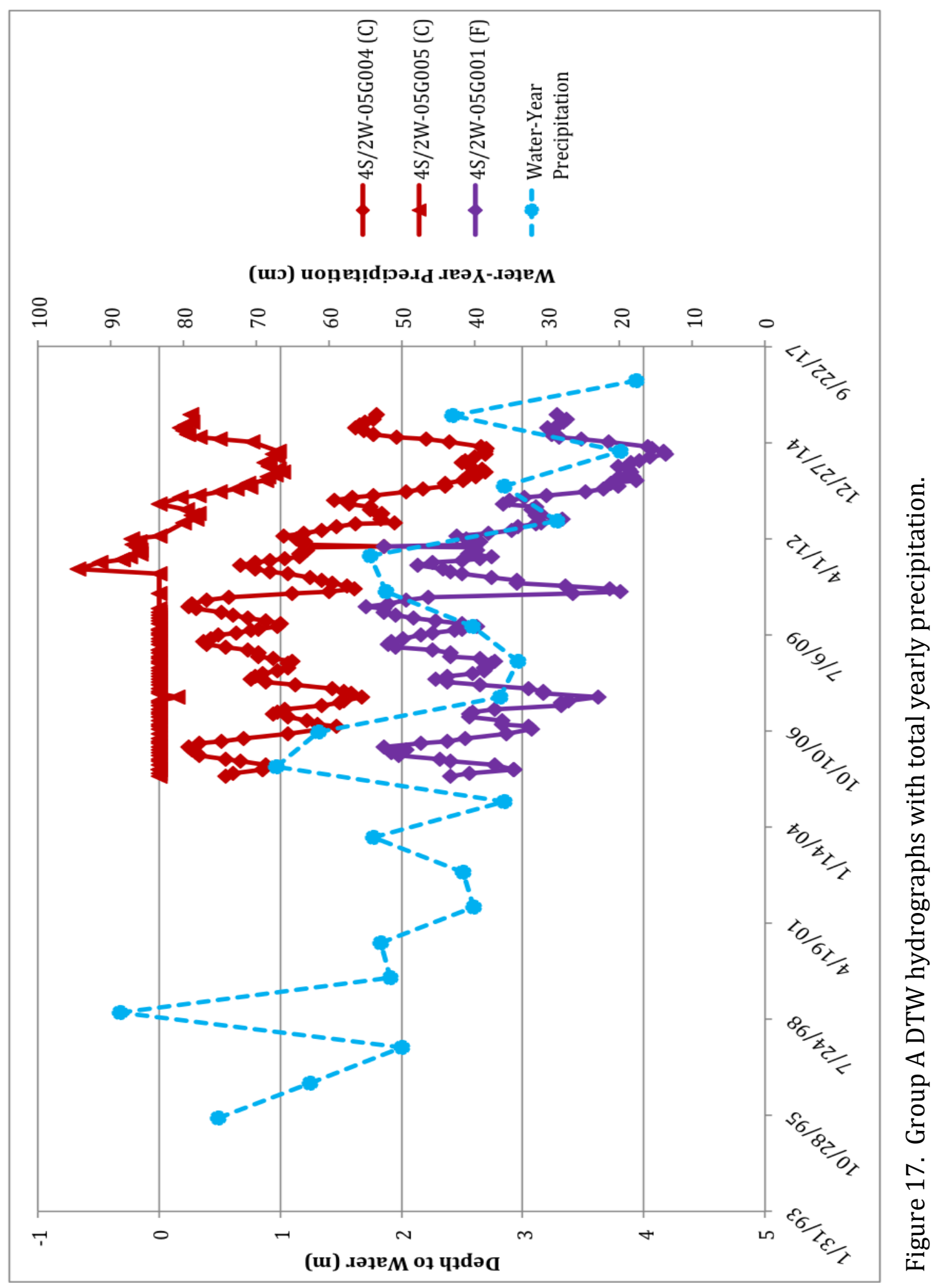




\section{Group B.}

Group B is located in the northern portion of the study area to the northeast of the Coyote Hills. The representative hydrographs for Group B (Fig. 18) represent one Newark Aquifer well, one Centerville Aquifer well, and one Deep Aquifer well. The deeper aquifers, focusing on the Centerville and Deep Aquifer wells, behave nearly identical to one another sharing a comparable DTW.

Even with decreased recharge to the basin during the afore-mentioned years, Centerville Aquifer wells within this region remained artesian within the spring months, recovering sufficiently during low precipitation years. The hydrograph provides clear indication of a strong seasonal effect (pre-1998) due almost certainly to pumping, demonstrated by the Centerville and Deep aquifer wells increased DTW measurements. Additionally, precipitation from 1995 to approximately the spring of 2010 was sizable enough to allow water levels to recover during low precipitation years up until spring of 2010. Around the spring of 2010 timeline, precipitation was too minimal to promote adequate aquifer recovery resulting in the waning of artesian conditions after 2006 and on into the complete absence of artesian condition from the fall of 2010 to 2015. 


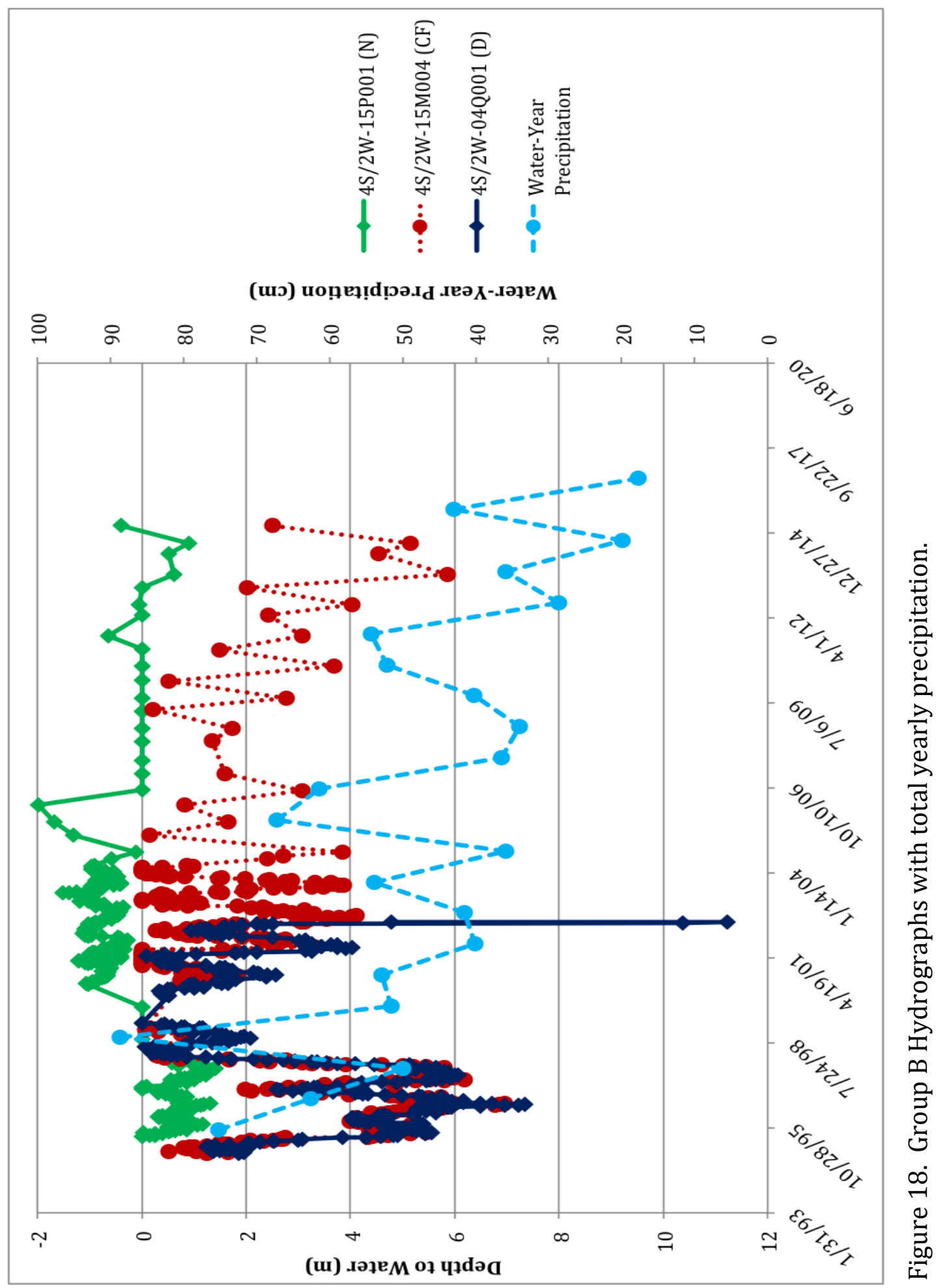


The Newark Aquifer within this region functions independently of the deeper aquifers. With a combined low topography and limited groundwater pumping within this portion of the basin, the Newark Aquifer wells within Group B remained artesian for a large portion of their monitoring events. This is evident within the hydrographs, which shows numerous artesian events as well as minimal seasonal variances within the well's DTW values compared to the deeper aquifer wells.

\section{Group C.}

Group C is located approximately east of the Coyote Hills. Group C's representative hydrographs are illustrated in Figure 19. Group C's hydrographs represent two Deep Aquifer wells, one Centerville Aquifer well, and two Newark Aquifer wells. The deeper aquifers (Centerville and Deep) both share similar DTW aquifer responses from 1995 to 2015. Both Deep Aquifer wells display DTW trends that are virtually identical to one another, but only one of the two wells went artesian. Well 4S/2W-27B002 went artesian twice as a result of the high rainfall observed in 1998. The non-artesian well 4S/2W-26L001 exhibits an identical reduction in DTW for the same dates and rainfall events, just offset within the hydrograph in response to differences in topography between both wells' reference point elevations of $1.95 \mathrm{~m}$. Variation in reference point elevations between the two Deep Aquifer wells allowed the lower-elevation well to go artesian while the higherelevation well had a reference point elevation above the potentiometric surface. 


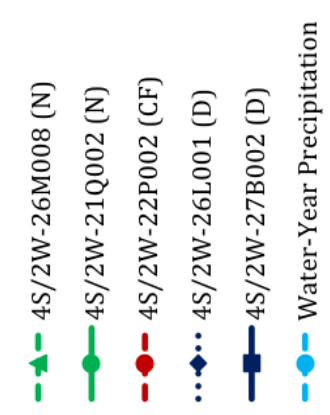

(uэ) uọ̣eฺ!
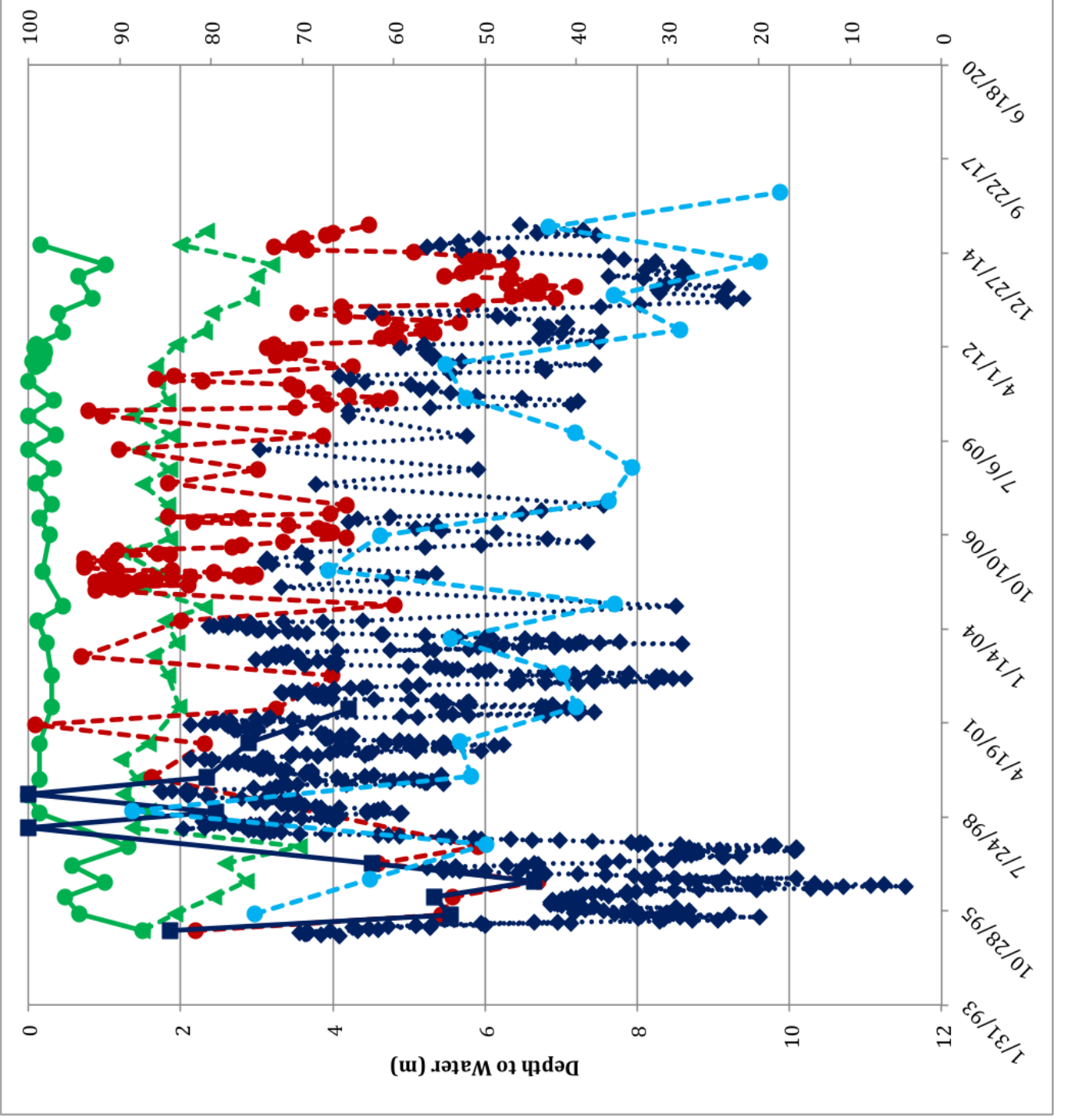

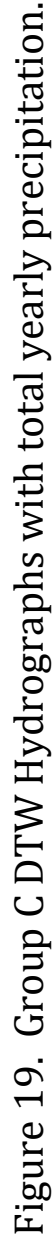


The Centerville well only went artesian once between 1995 and 2015, in the spring of 2001. Well 4S/2W-22P002 exhibits a decrease in DTW during the well's one artesian event, most likely in response to a small precipitation event which can be observed in the Deep Aquifer well (4S/2W-26L001) near the same monitoring event. The slow overall recession in precipitation following the high rainfall in 1998 hydraulically affected the Centerville Aquifer by exhibiting slight increases in DTW values with time following the general negative precipitation trend.

Group C has two Newark Aquifer wells presented in the hydrographs, one artesian and one non-artesian. Well 4S/2W-21Q002 has been monitored from 1995 to 2015 and has gone artesian approximately $60 \%$ of the total monitoring events. This periodically-artesian well has a reference point elevation that is $2.71 \mathrm{~m}$ lower than the non-artesian well, 4S/2W-26M008. The difference in reference point elevations is reflected in the difference in DTW in the hydrographs. Well 4S/2W$26 \mathrm{M} 008$ follows a trend similar to that of artesian well 4S/2W-21Q002, but offset by approximately 1.5 to $2.1 \mathrm{~m}$. The lower TOC reference elevation of 4S/2W-21Q002 (1.5 MASL) would facilitate the well's frequent artesian conditions. Seasonal influences on DTW values within the shallow Newark Aquifer are much less accentuated than in the deeper (Centerville and Deep) aquifers. Furthermore, differences in patterns of seasonal response provide evidence within Group C that the Newark Aquifer is hydraulically independent of the Centerville and Deep Aquifers. 


\section{Group D.}

Group D is located in the south-southeast portion of the study area. Group D's hydrographs, shown in Figure 20, consist of two Newark Aquifer wells, two Centerville Aquifer wells, one Fremont Aquifer well, and one Deep Aquifer well. Depicted in the Group hydrographs, wells screened within the deeper aquifers (Centerville, Fremont, and Deep) behave similarly to one another. In addition to the deeper aquifer wells' analogous water level responses with time, they behave very similarly to the precipitation line, inferring that precipitation has a direct influence on this portion of the basin's deeper aquifers. The large decrease in the Centerville well's (5S/1W-07H001) DTW during 1998 coincides with the substantial precipitation during the same year; high precipitation caused recharge to increase and groundwater levels to rise. Seasonal increases in groundwater elevation, shown by marked decreases in DTW, occur consistently during spring months for the Centerville, Fremont, and Deep Aquifers.

The Newark Aquifer wells' DTWs, represented by green lines, vary from the precipitation line and behave independently from the deeper aquifer wells. Figure 20 indicates that the Newark Aquifer does display seasonal variations similar to those of the deeper aquifers but those variations are much less accentuated. Additionally, the two Newark Aquifer wells behave hydraulically analogous to one another over time. These wells display a slight offset in DTW values over time resulting directly from the difference of approximately $0.9 \mathrm{~m}$ between the two wells' reference point elevations. 


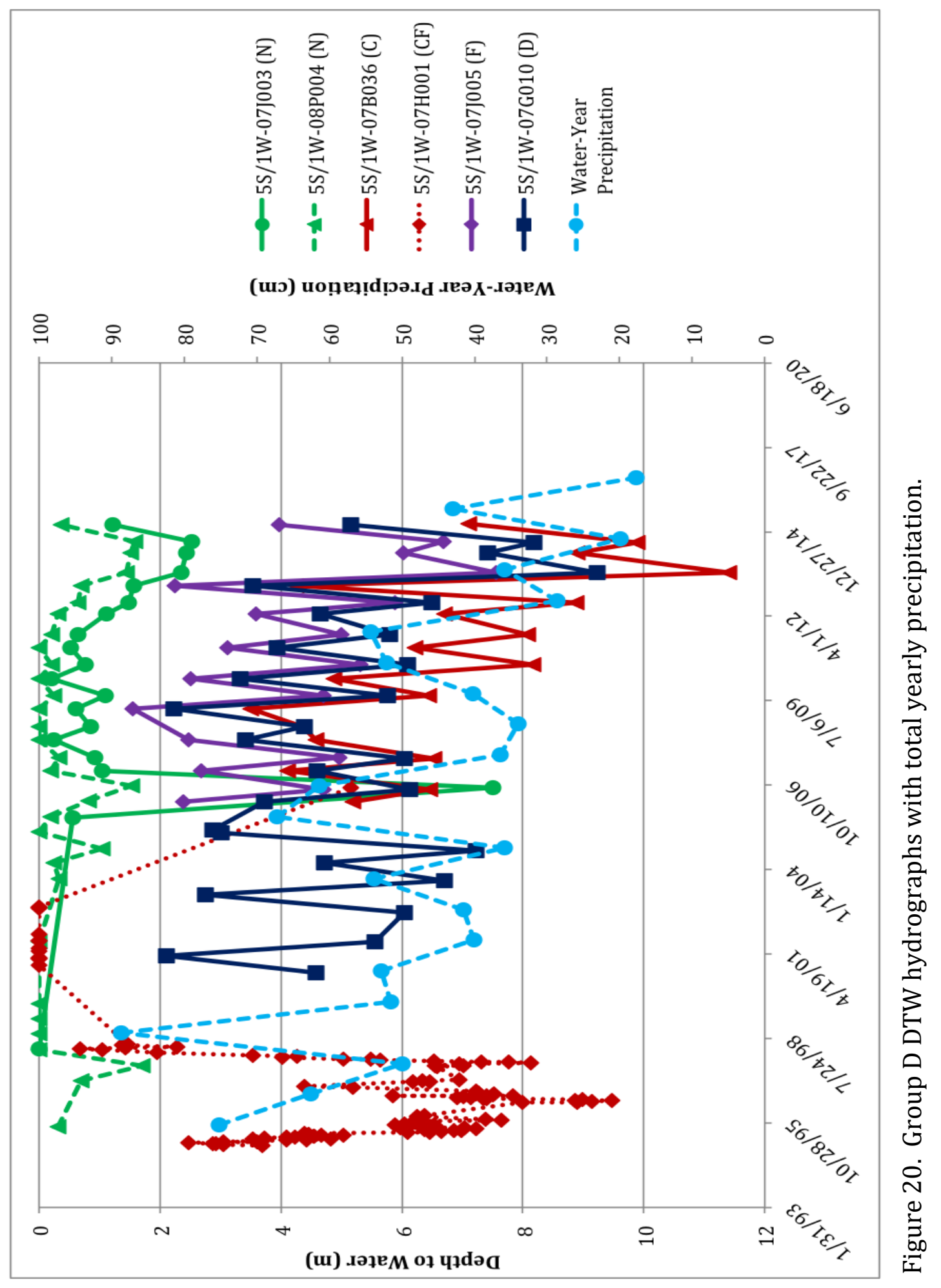




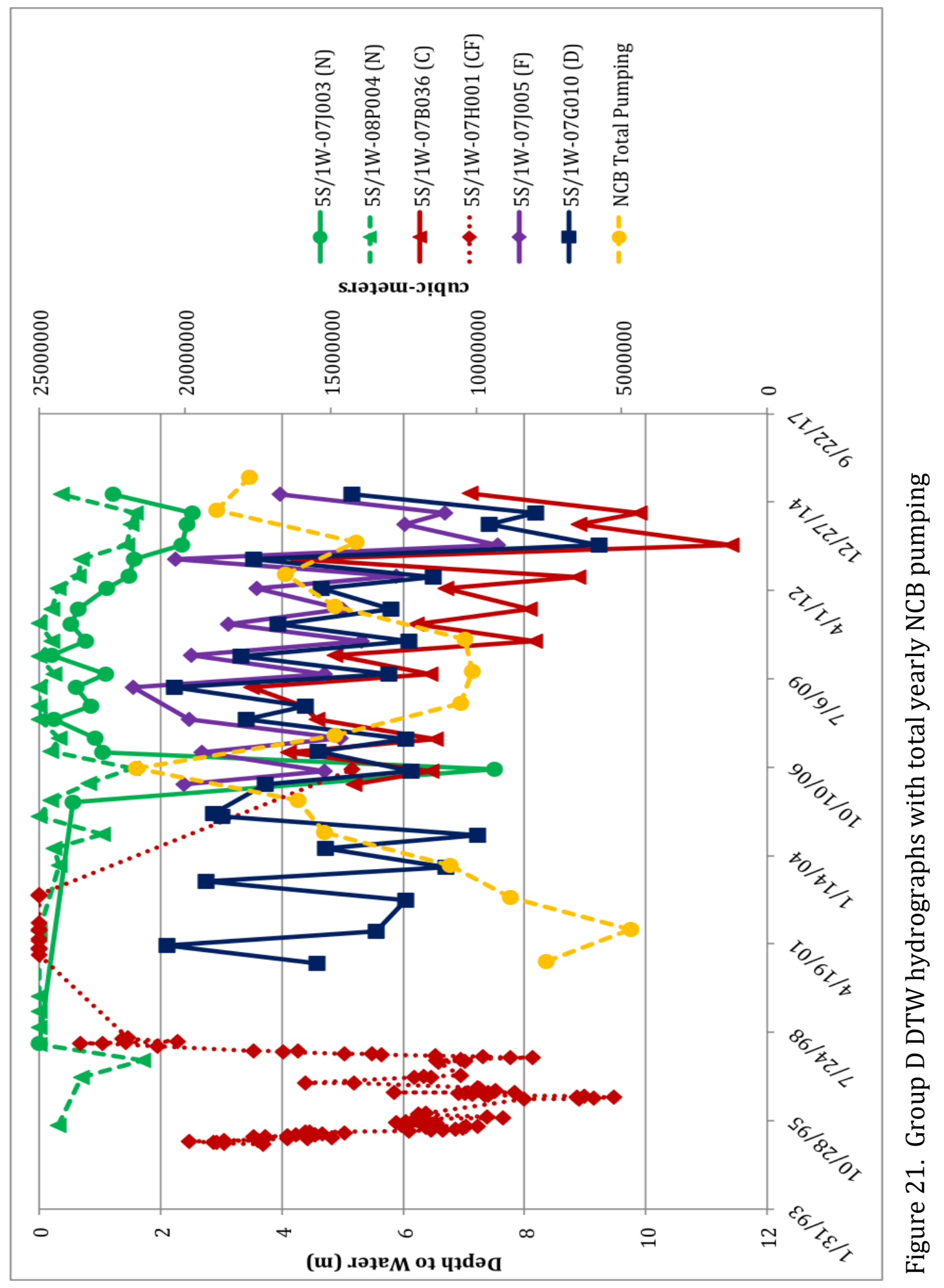


Generally, artesian conditions throughout the Newark Aquifer within Group D are not as directly affected by seasonal precipitation, compared to the deeper aquifer wells. Newark artesian conditions are observed throughout both fall and spring monitoring events. The topography of Group D has low elevations for the Newark Aquifer wells, averaging approximately 3.12 MASL. This has a major influence on artesian conditions as shown by well 5S/1W-07J003, which has the highest reference elevation of 4.01 MASL when compared to adjacent Newark Aquifer wells. Out of 20 monitoring events, 5S/1W-07J003 has only gone artesian three times, significantly fewer times than neighboring, lower-reference-pointelevation Newark Aquifer wells.

It is important to examine influences brought upon by pumping within Group D because of its close proximity to the ARP and Morton Salt wells located as little as $2.25 \mathrm{~km}$ from the monitoring wells within Group D. A yearly total pumping line, designated by a dashed yellow line, was added to the hydrographs in Figure 21. This helped to identify correlations between large decreases in DTW measurements and high-volume pumping. Pumping data acquired from ACWD indicates that the highest volume of water was pumped out of the basin in 2006 (primarily from the ARP and Morton Salt wells) from the Newark, Centerville, and Fremont Aquifers. As a direct response, Newark Aquifer well 5S/1W-07J003 and Centerville Aquifer well 5S/1W-07H001 both show a significant increase in DTW values measured in 2006. 


\section{Group E.}

Group E is located towards the southwest of the study area, adjacent to San Francisco Bay. The Group E hydrographs (Fig. 22) represent two Newark Aquifer wells, one Centerville Aquifer well, one Fremont Aquifer well, and two Deep Aquifer wells. Hydraulically, Group E behaves distinctly from the other four Groups throughout the basin. There is a gradient reversal causing the Deep Aquifer wells to go artesian frequently while the shallowest Newark Aquifer remains mostly nonartesian. The Deep and Fremont aquifer wells have decreases in their DTW values causing the wells to both go artesian notably above the corresponding TOC reference point elevations between 2011 and 2013, opposite to that of the precipitation line. Such a large shift in DTW values may result from variances in prior well monitoring methods. The Fremont and Deep wells were installed in 2007 and from that first monitoring date until 2011, DTW measurements from both wells were equal to zero, which may result from not being able to properly measure the true hydraulic head above the TOC.

The Newark Aquifer within Group E functions independently from the Centerville, Fremont, and Deep Aquifers. Generally, throughout the BHF sub-basin, Newark Aquifer wells display lower DTW measurements and develop artesian conditions more frequently than the Centerville, Fremont, and Deep Aquifers. In contrast, Group E's Newark wells exhibit higher DTW values and less frequent occurrences of artesian events. 


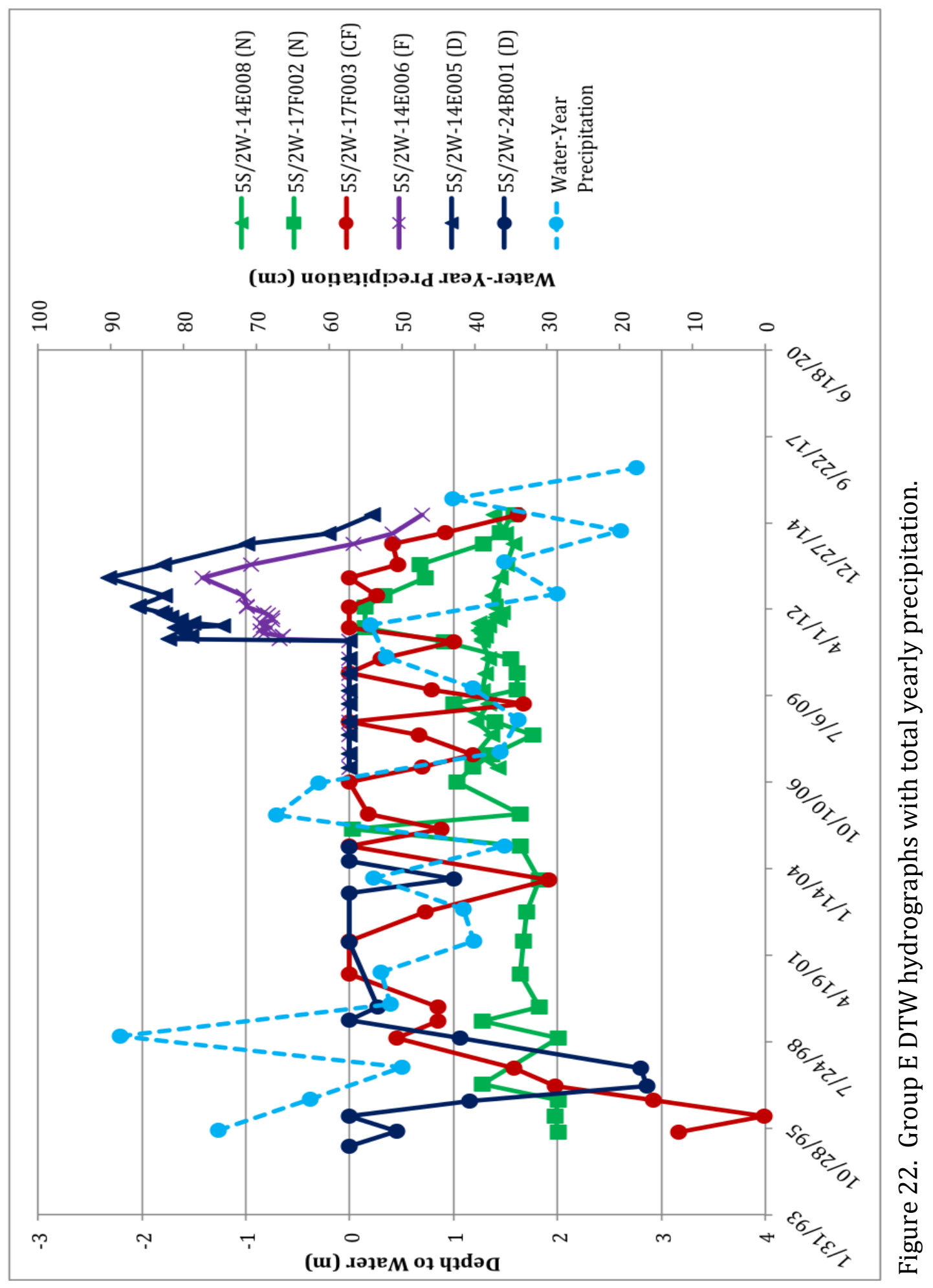


Temporally, the Newark Aquifer well 5W/2W-17F002 is more highly influenced by seasonal fluctuations in precipitation than the other Newark Aquifer well (5S/2W14E008) within Figure 22, which has never gone artesian. Well 5S/2W-14E008 has been monitored a total of 28 times between 2007 and 2015 and maintains a very consistent DTW when compared to artesian well 5S/2W-17F002 which displays substantial seasonal fluctuations in DTW over time. 


\section{DISCUSSION}

The results of this study provide a qualitative assessment of the spatial distribution and important controlling factors of artesian conditions throughout the study area's four-aquifer system. Well-density plays an important role when studying artesian conditions in the NCB. The Fremont Aquifer and Deep Aquifer have limited data on artesian conditions because of the low well-density. Additionally, the variable nature of water level measurements of ACWD's well network makes understanding temporal influences on artesian conditions difficult, creating a limited qualitative analysis.

\section{Factors Controlling Artesian Conditions}

\section{Topography}

Topography within the study area plays a central role in determining whether a region within the study area will be under artesian conditions. Results from the study show that all artesian wells within the BHF sub-basin occur in regions where reference point elevations are less than 5.2 MASL, and predominantly less than 3.0 MASL, regardless of which aquifer a well was screened. Ground surface elevation dictates the spatial distribution of artesian wells, confining them to lower elevated portions of the BHF sub-basin, down-gradient of the fan's apex towards the bay margin. In addition, the Newark and Centerville Aquifers were found to have artesian wells near adjacent non-artesian wells monitored on the same date within certain regions throughout the basin. The study found that approximately $40 \%$ of these occurrences are a result of two adjacent wells having considerable differences 
in reference point elevations, owing to local topographic differences. Localized differences in topography would place a nearby non-artesian well's reference point elevation above the local potentiometric surface when compared to a neighboring artesian well.

\section{Groundwater Inputs and Outputs}

Groundwater inputs and outputs affect the spatial and temporal variability of artesian conditions within low topographic regions of the basin. Generally, greater precipitation during early spring months produces a greater number of artesian events than are seen in the fall months which are proceeded by a prolonged period of low precipitation. The greatest annual precipitation total measured within the basin between 1995 and 2015 was during the 1998 water year, resulting in a number of wells within the basin going artesian exclusively as a result of that one heavy precipitation year. A majority of wells found to go artesian exclusively during that time period were located more eastward, toward higher TOC reference-point elevations. Wells drilled within higher elevation portions of the basin require a substantially larger input of water to produce artesian conditions compared to those in lower topographic regions. In addition, based on the similarity of hydrographs, the deeper aquifers (Centerville, Fremont, and Deep) are in good hydraulic connection with one another. The Newark Aquifer functions independently from the three deeper alluvial systems owing to the low permeability aquitard separating the Newark from the deeper aquifers. Additionally, the Newark Aquifer's potentiometric surface typically does not respond as strongly to 
fluctuations in precipitation compared to the deeper aquifers.

Water outputs were created by high-volume pumping at ACWD production wells (not standby wells or infrequently-pumped production wells), primarily the ARP wells of interest (Cedar $1 \& 2$, Darvon $1 \& 2$, Bellflower, and Farwell). Additionally, the privately-owned Morton Salt well, pumping out of the Fremont and Deep aquifers, was of interest. The production wells are located at lower elevations where artesian conditions are more likely to occur. Groundwater-elevation contour maps previously created and published within ACWD's semiannual (spring/fall) GWMR's were acquired and studied for each of the four aquifers within the BHF sub-basin spanning 2001 to 2013 and 2015 (ACWD, 2002 through 2014 and 2016). Goundwater-elevation contour maps were published by ACWD in their semi-annual GWMR's starting in 2001. The contour maps provided a visual aid, showing locations within specific aquifers where significant cones of impression were produced by localized, high-volume pumping. Within ACWD GWMRs, a cone of depression created from the ARP (Cedar $1 \& 2$, Darvon $1 \& 2$, Bellflower, and Farwell) wells pumping the Centerville, Fremont, and Deep Aquifers can be observed throughout most of the study period. Artesian conditions do not occur inside of the cone of depression, as illustrated in figures 8 through 11 by the abundance of non-artesian wells (blue circles) in the vicinity of the ARP and Morton Salt wells. The Newark aquifer appears to be less influenced by pumping at and around the ARP wells. This is because over 2.5 times as much groundwater was pumped from the Centerville and Fremont aquifers as from the Newark Aquifer 
from 2000 and 2015. This lower volume of pumping meant that wells screened within the Newark Aquifer were artesian more frequently and in closer proximity to the ARP wells when compared to the deeper aquifer wells. Groundwater-elevation contours constructed for the Newark Aquifer generally display a southwest trending hydraulic gradient with little to no cone of depression produced by the ARP wells from 2001 to 2015 .

There are two remaining unanswered questions: a) what causes the consistent downward hydraulic gradient observed at Group A, and b) why does only Group E show more consistent artesian conditions for the deeper aquifers compared to the shallow aquifer? 


\section{CONCLUSIONS}

Artesian conditions in the NCB are observed within topographic regions less than 5.2 MASL but predominantly within topographic regions less than 3.0 MASL. Artesian wells are found to occur toward the distal extent of the fan, typically in wells near the shoreline at topographic lows.

Water inputs affect the temporal variability of artesian conditions throughout the study area. Hydrographs show the seasonal effects on individual wells with artesian conditions taking place during, but not limited to, spring months. The Newark Aquifer contains the greatest number of artesian wells with more frequent artesian events when compared to the Centerville Aquifer. Unfortunately, welldensity is low within the Fremont and Deep aquifers, resulting in a limited quantitative analysis of artesian events within the two deepest aquifers.

Further work to increase our understanding of artesian conditions would include the continuous monitoring of the current well network along with the installation of additional monitoring wells within the Fremont and Deep aquifers. In addition, it would be beneficial to further understand the local hydrology within Group A and E by reviewing hydrological information from neighboring groundwater basins. This would permit a better understanding of the effects of the hydrology by adjacent basins of the hydrology of the BHF sub-basin. 
Pumping directly affects artesian conditions in wells within localized regions that are in close proximity to high-volume pumping. Obtaining pumping information from neighboring groundwater basins could provide additional insight into the effects of outside pumping on ACWD's well network. 


\section{REFERENCES CITED}

Alameda County Water District (ACWD), 2002, Groundwater Monitoring Report $2001,64 \mathrm{p}$.

Alameda County Water District (ACWD), 2003, Groundwater Monitoring Report $2002,60 \mathrm{p}$.

Alameda County Water District (ACWD), 2004, Groundwater Monitoring Report 2003, 58 p.

Alameda County Water District (ACWD), 2005, Groundwater Monitoring Report $2004,57 \mathrm{p}$.

Alameda County Water District (ACWD), 2006, Groundwater Monitoring Report 2005, $57 \mathrm{p}$.

Alameda County Water District (ACWD), 2007a, Groundwater Monitoring Report 2006, 57 p.

Alameda County Water District (ACWD), 2007b, Southwest Niles Cone Groundwater Monitoring Project, 190 p.

Alameda County Water District (ACWD), 2008, Groundwater Monitoring Report 2006, $58 \mathrm{p}$.

Alameda County Water District (ACWD), 2009, Groundwater Monitoring Report 2008, 58 p.

Alameda County Water District (ACWD), 2010, Groundwater Monitoring Report 2009,60 p.

Alameda County Water District (ACWD), 2011, Groundwater Monitoring Report 2010, $61 \mathrm{p}$.

Alameda County Water District (ACWD), 2012, Groundwater Monitoring Report $2011,68 \mathrm{p}$.

Alameda County Water District (ACWD), 2013, Groundwater Monitoring Report 2012, $72 \mathrm{p}$.

Alameda County Water District (ACWD), 2014, Groundwater Monitoring Report 2013, 73 p. 
Alameda County Water District (ACWD), 2015, Survey Report on Groundwater Conditions: Alameda County Water District Groundwater Resources Division, $39 \mathrm{p}$.

Alameda County Water District (ACWD), 2016, Groundwater Monitoring Report 2015, $71 \mathrm{p}$.

Chamberlin, T. C., 1885, The Requisite and Qualifying Conditions of Artesian Wells. U.S. Geological Survey Annual Report 5, 131-175 p.

Clark, W.O., 1924, Groundwater in Santa Clara Valley, California: U.S. Geological Survey, Water Supply Paper 519, 209 p.

Department of Water Resources (DWR), 1967, Bulletin 118-1: Department of Water Resources Central Records, v. 1,122 p.

Klimchouk, A., 2005, Conceptualisation of Speleogenesis in Multi-Story Artesian Systems: a Model of Transverse Speleogenesis: International Journal of Speleology, v. 34, 45-64 p.

San Francisco Bay Regional Water Quality Control Board (SFBRWQCB), 2003, A Comprehensive Groundwater Protection Evaluation for the South San Francisco Bay Basins, $251 \mathrm{p}$.

USGS National Map Viewer, Raw data for Alameda County 1/3 arc-second DEM, https://viewer.nationalmap.gov/basic/ (November 2016).

Zhang, G. Z., 2001, GIS Spatial Statistics of the Groundwater in the Oak Ridge Moraine Area, Ontario [Master's Thesis], York University, 158 p. 
Appendix A: NCB Sub-Region (1-24) Hydrographs 


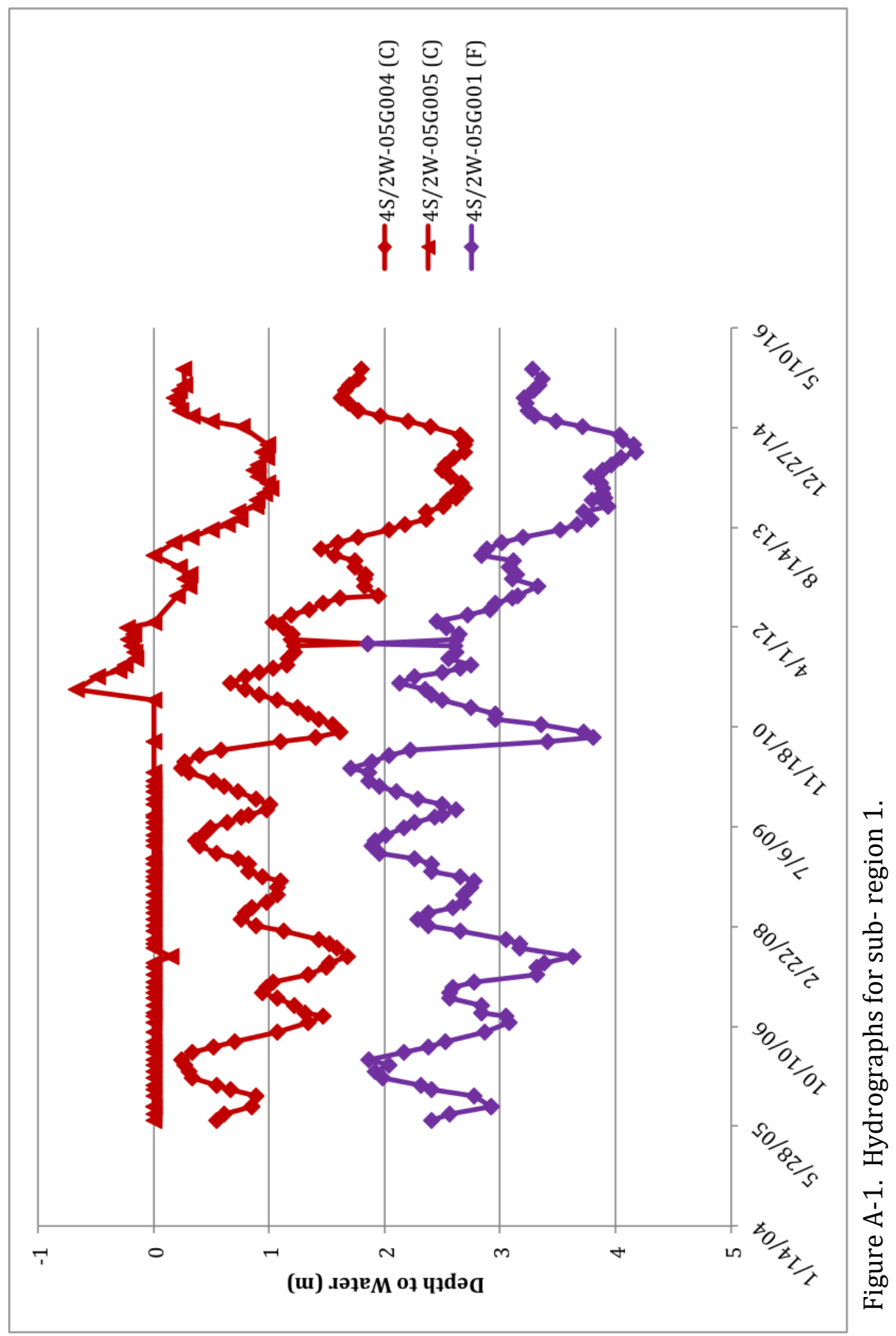




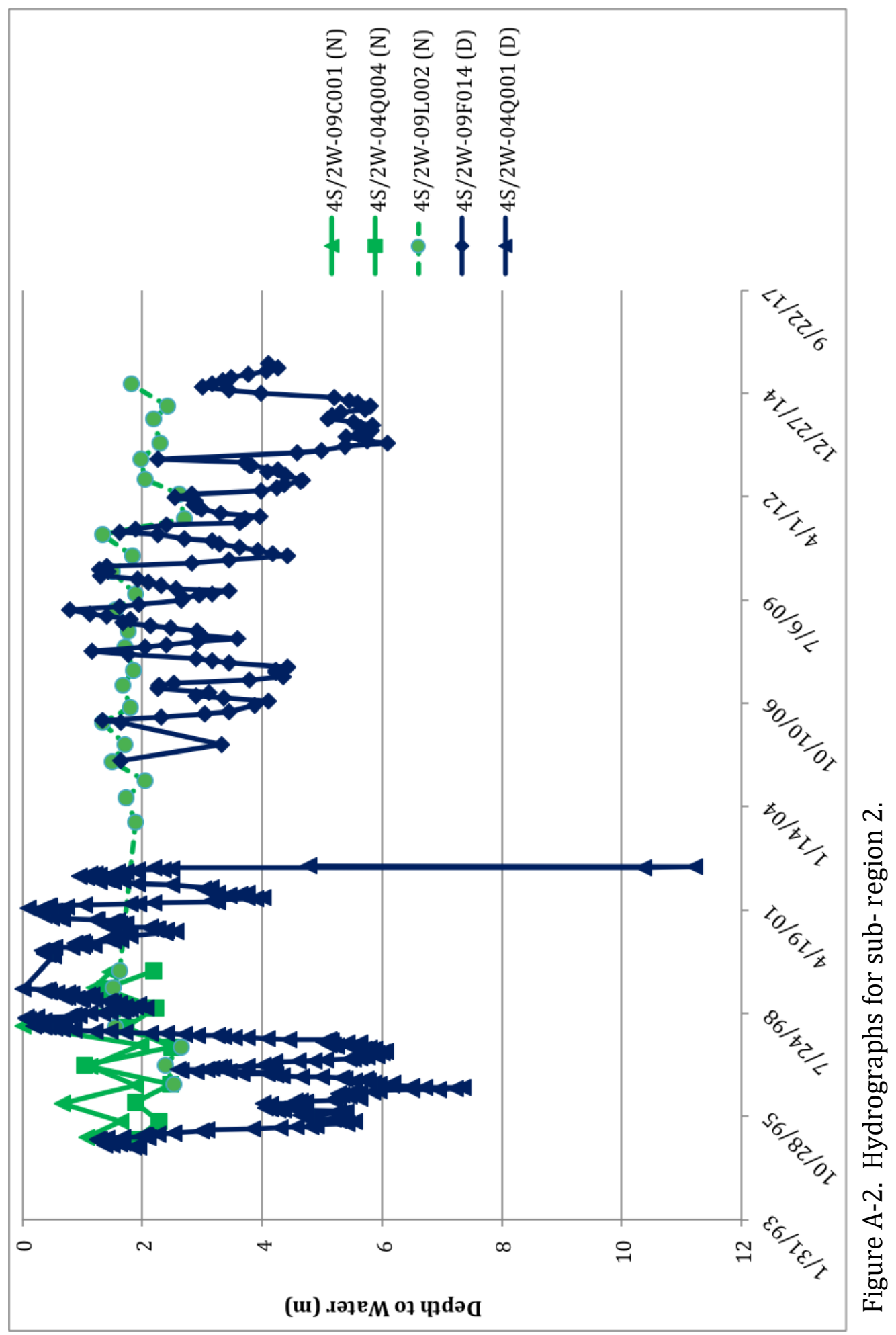




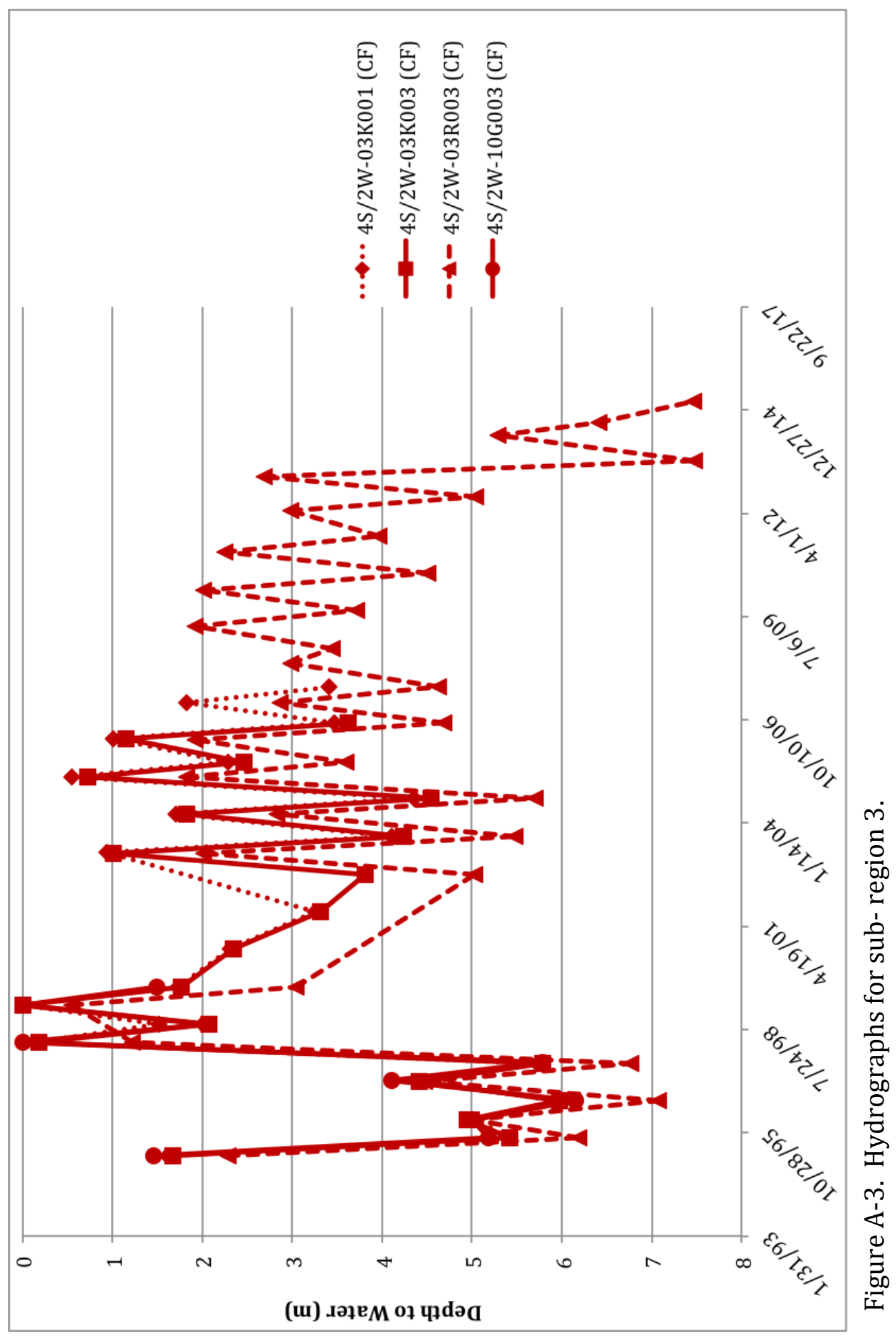




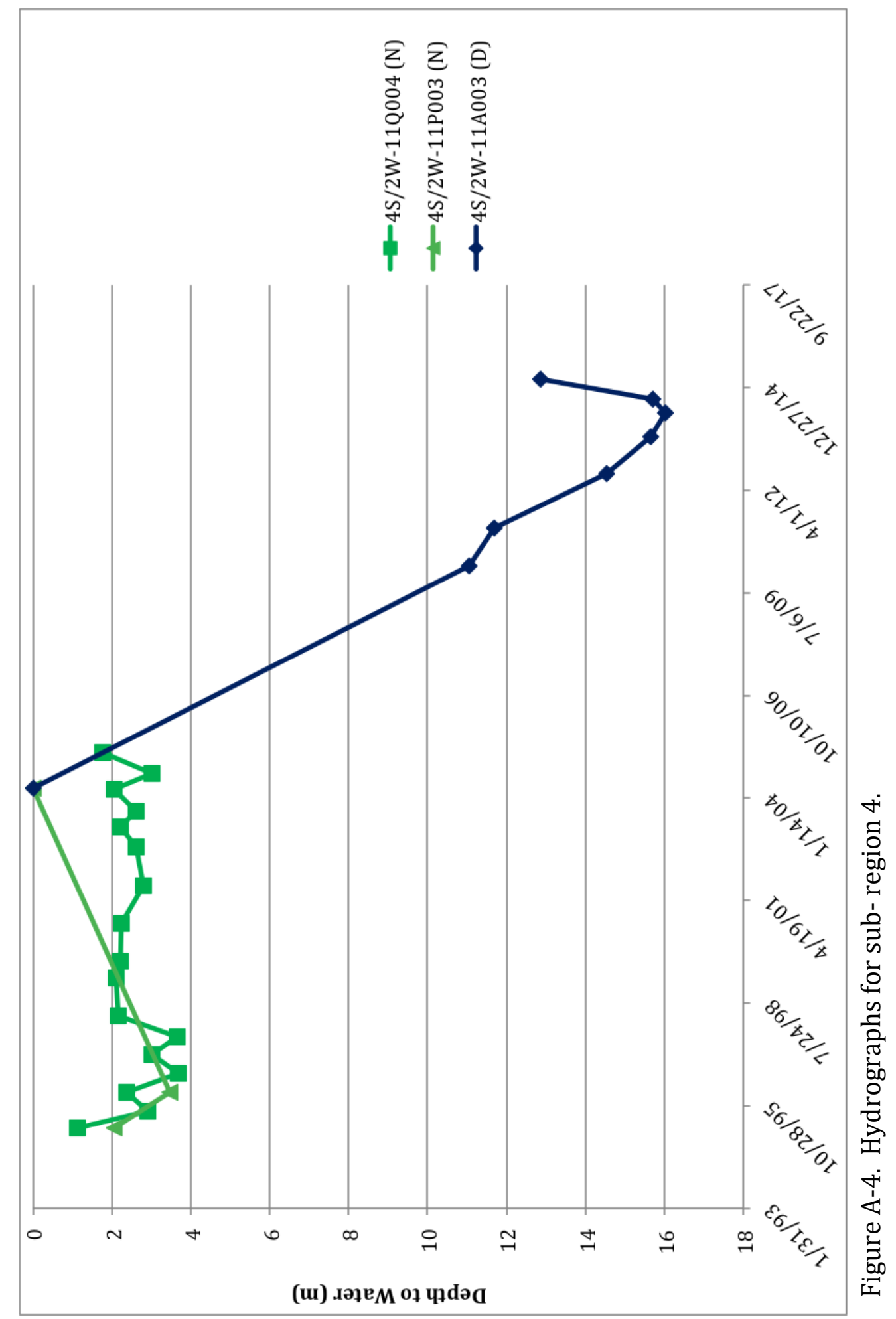




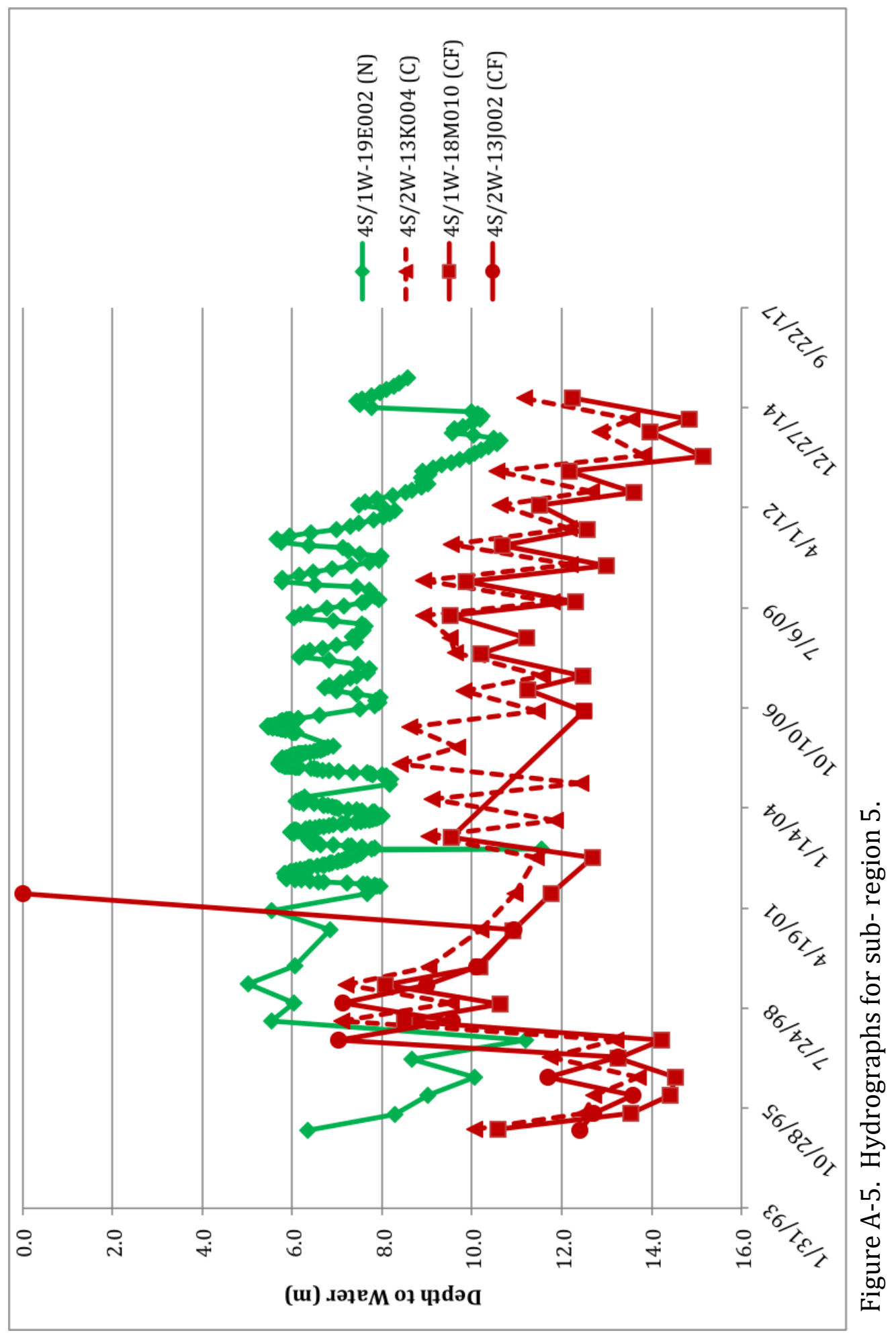




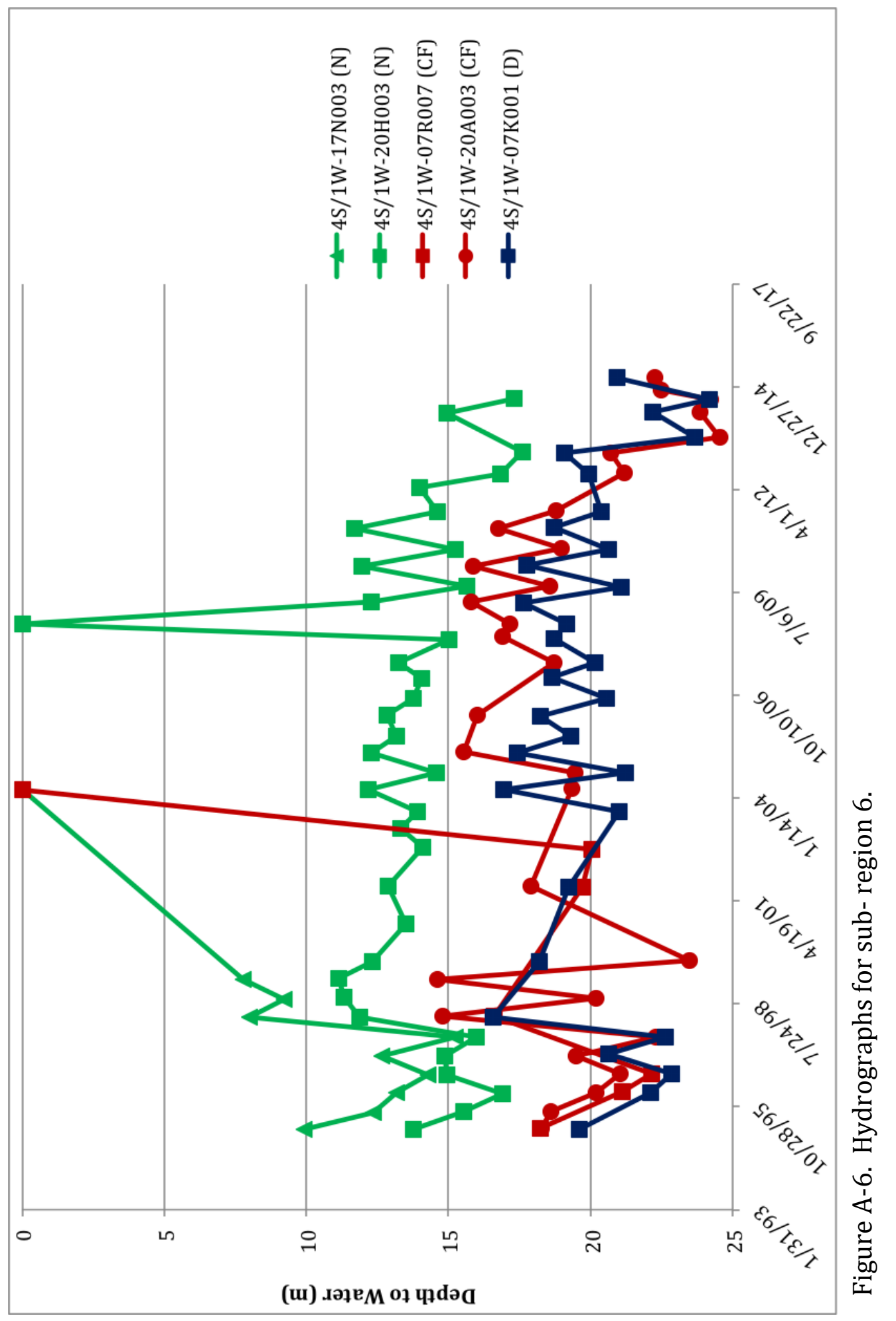




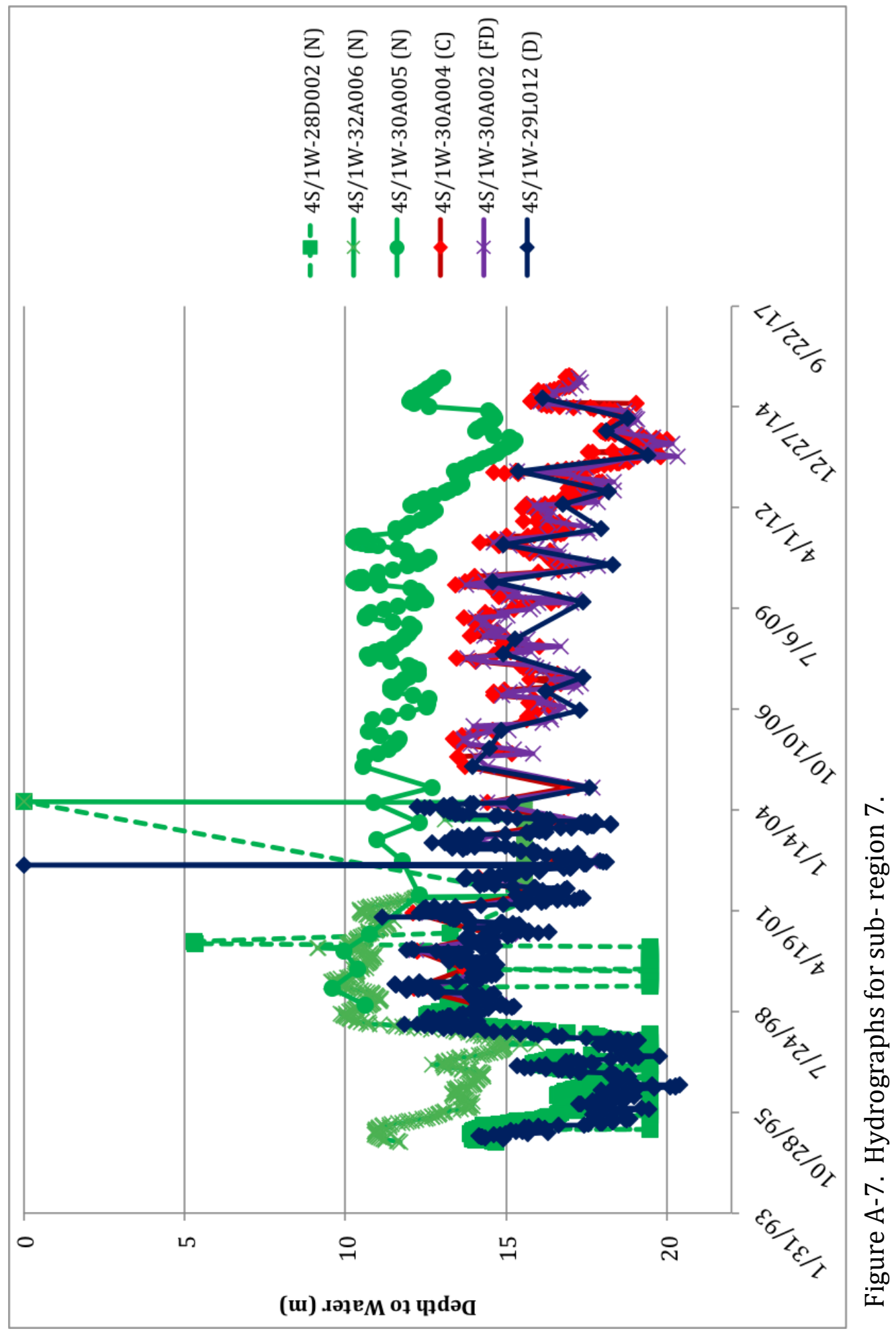




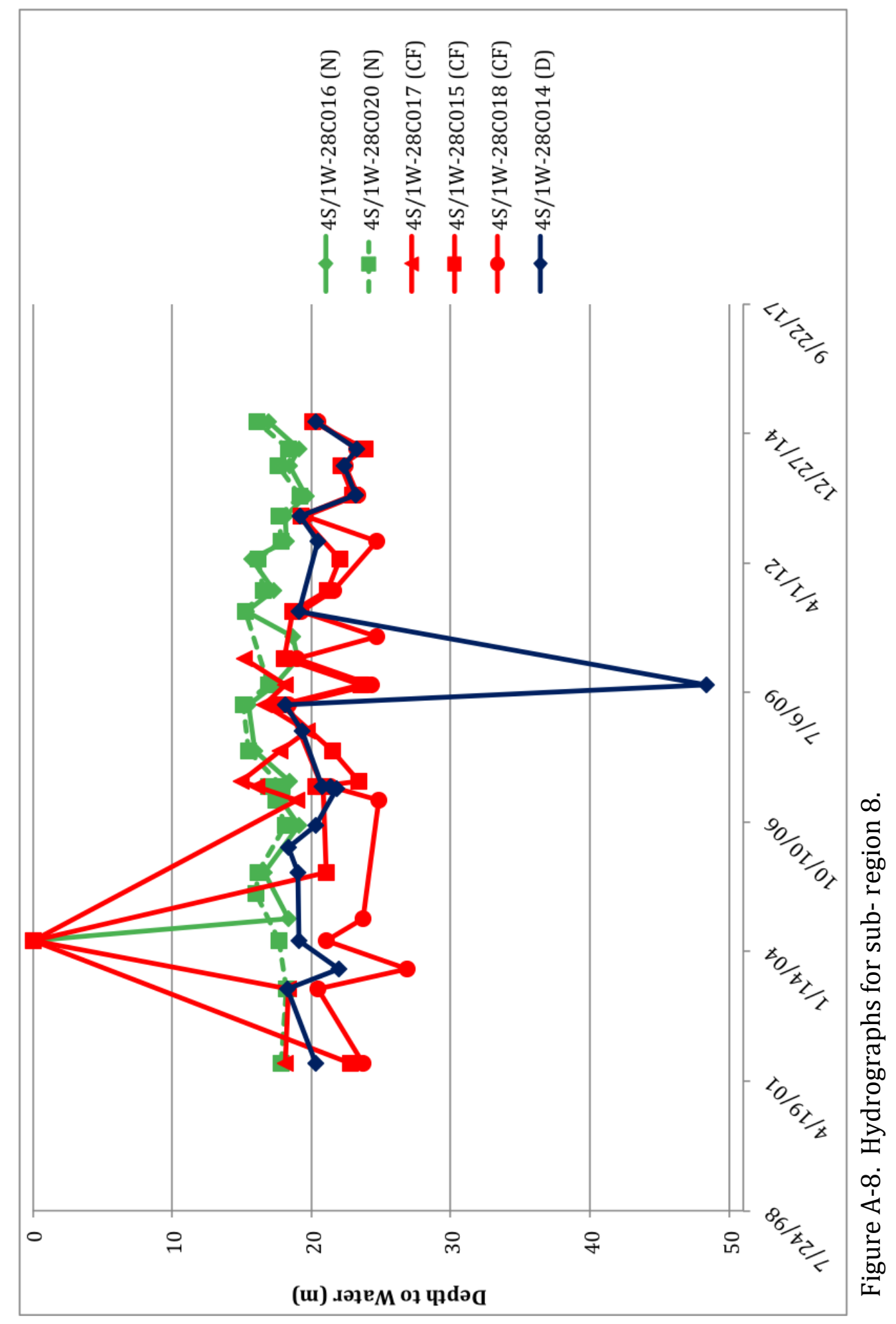




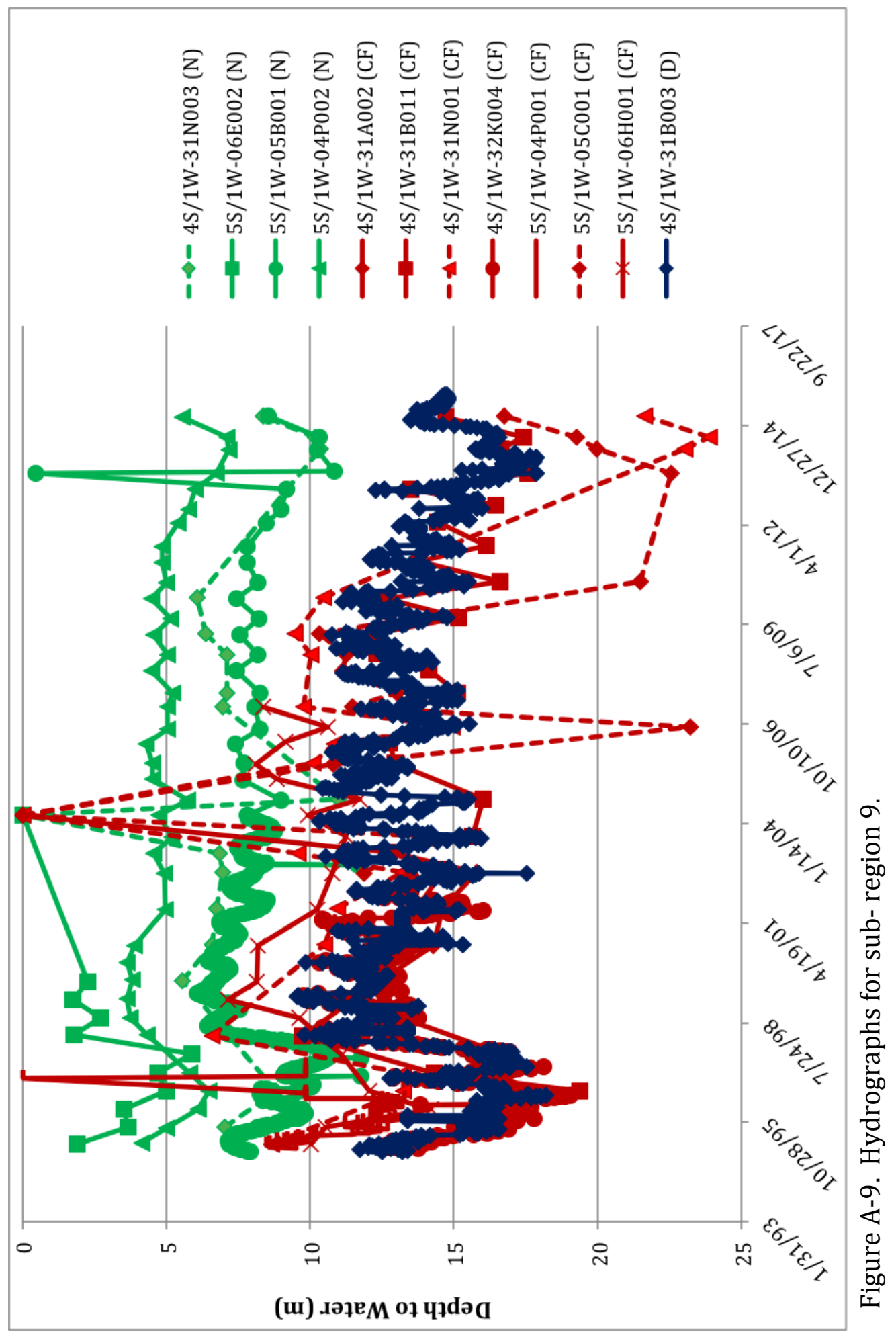




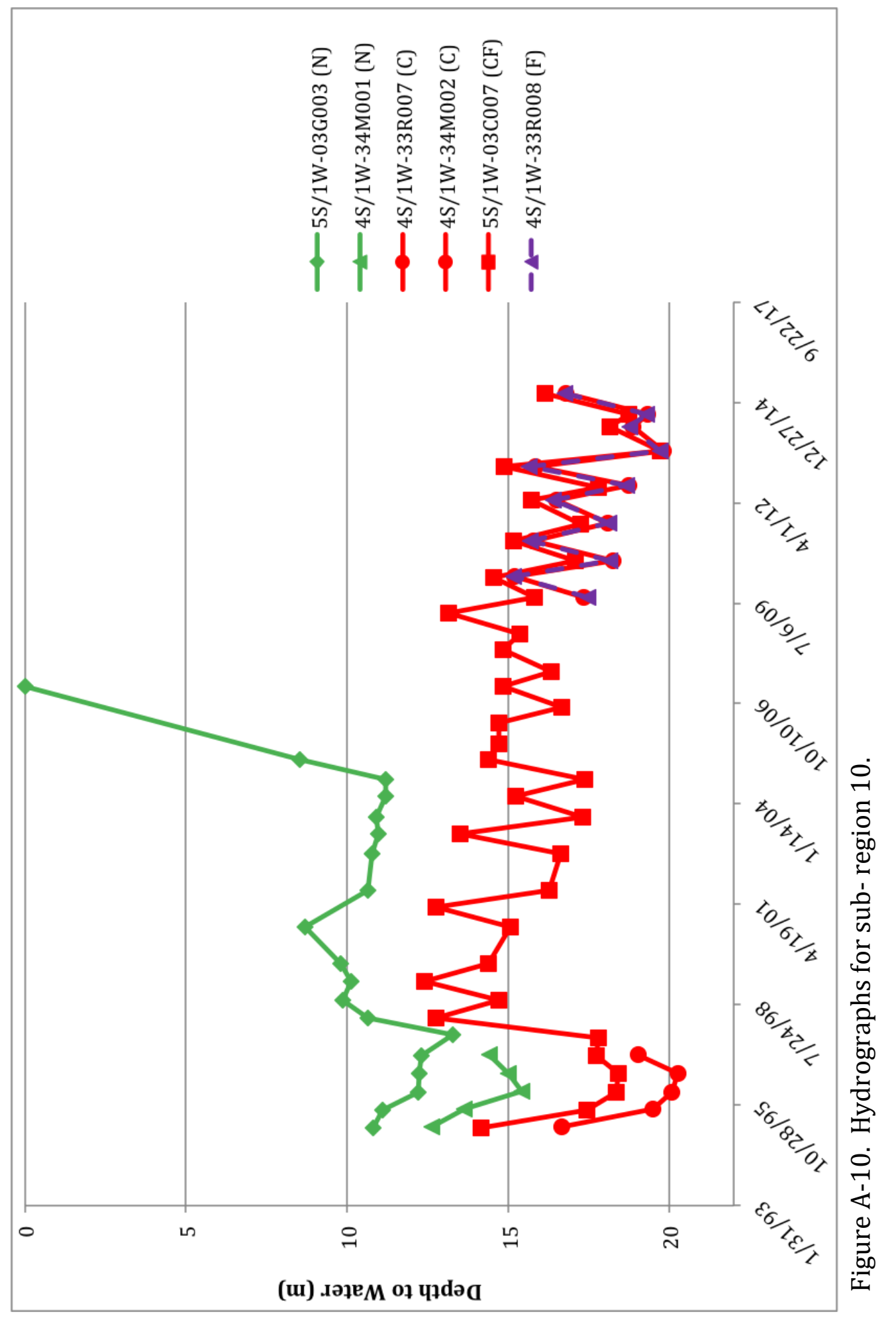




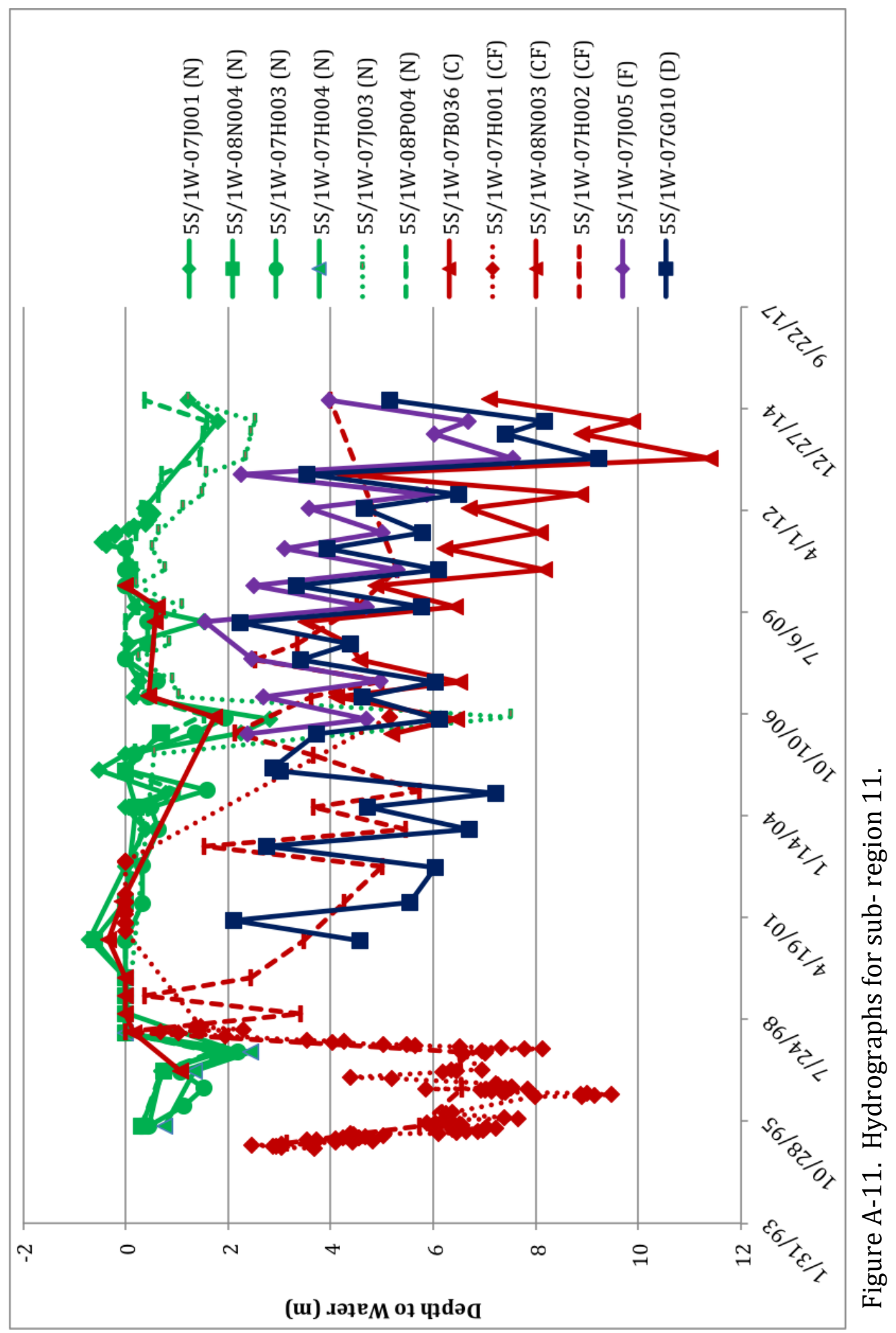




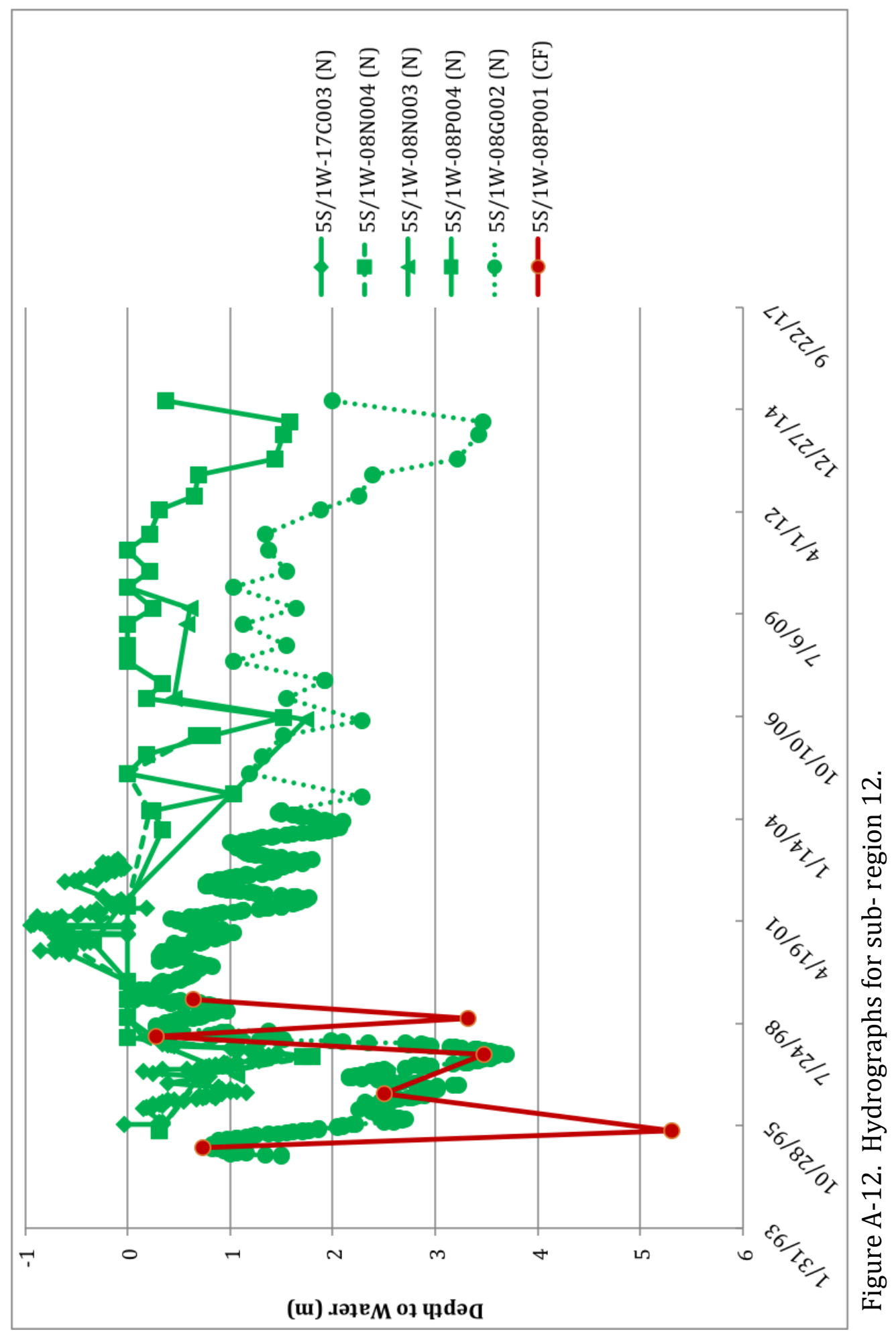




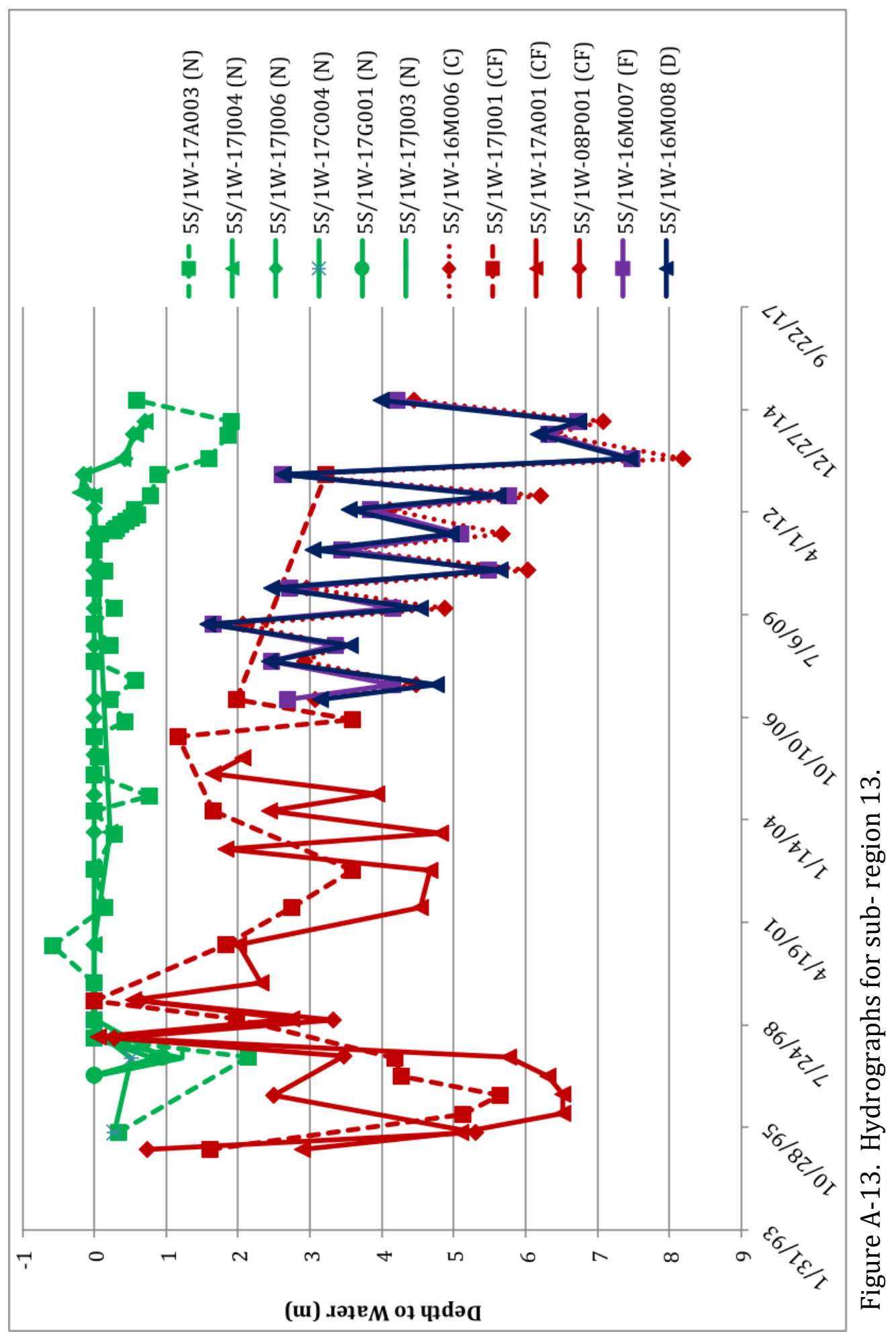




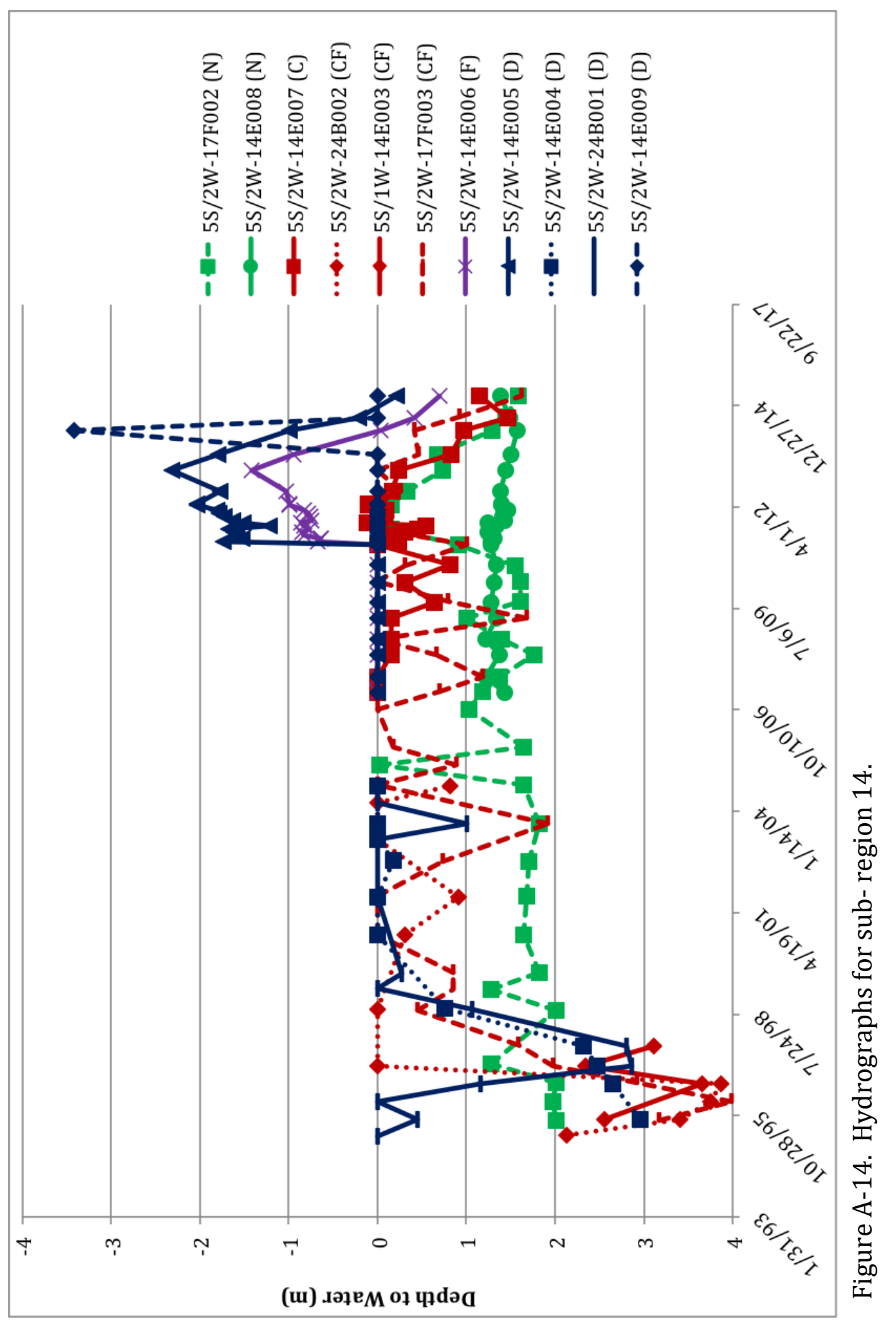




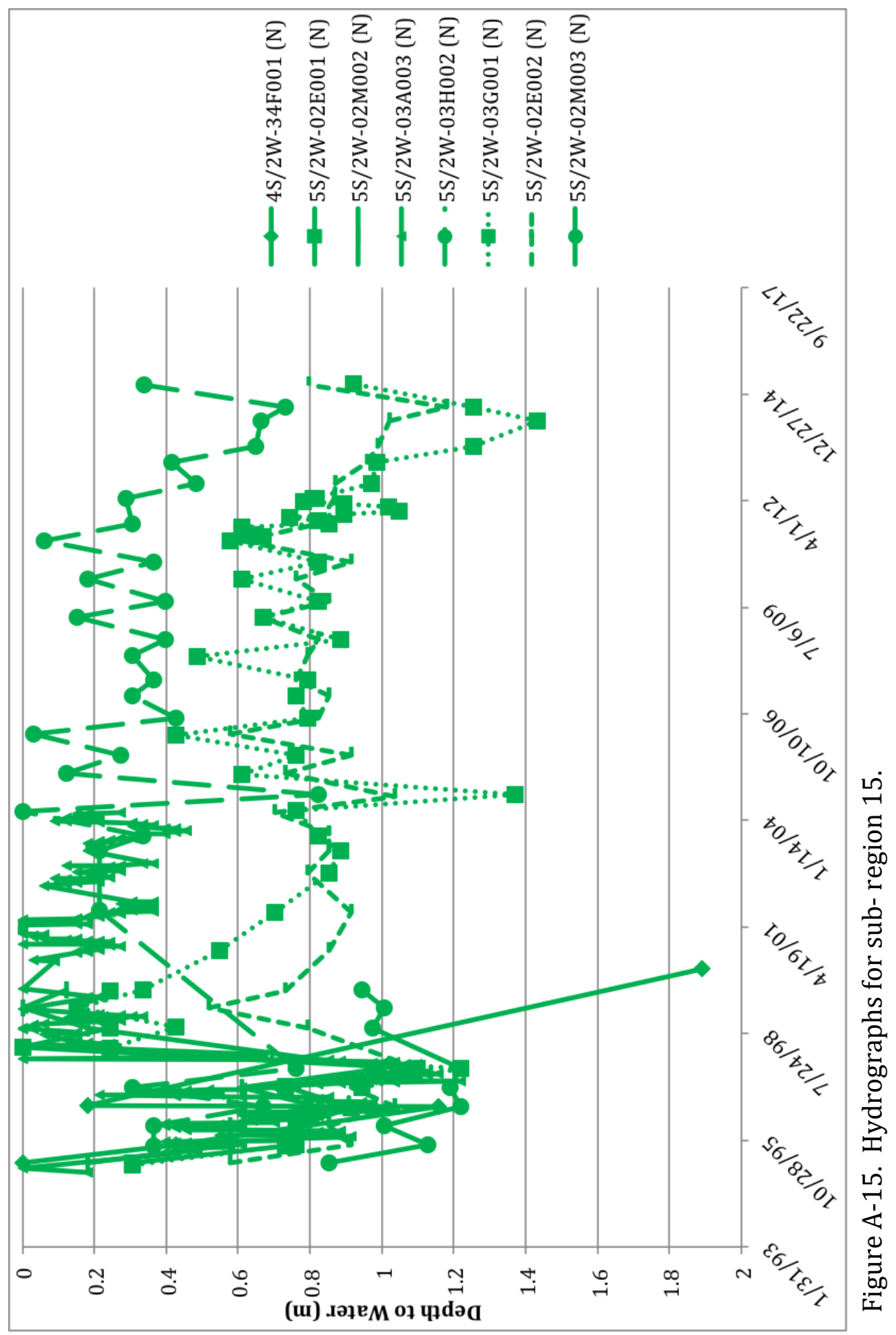




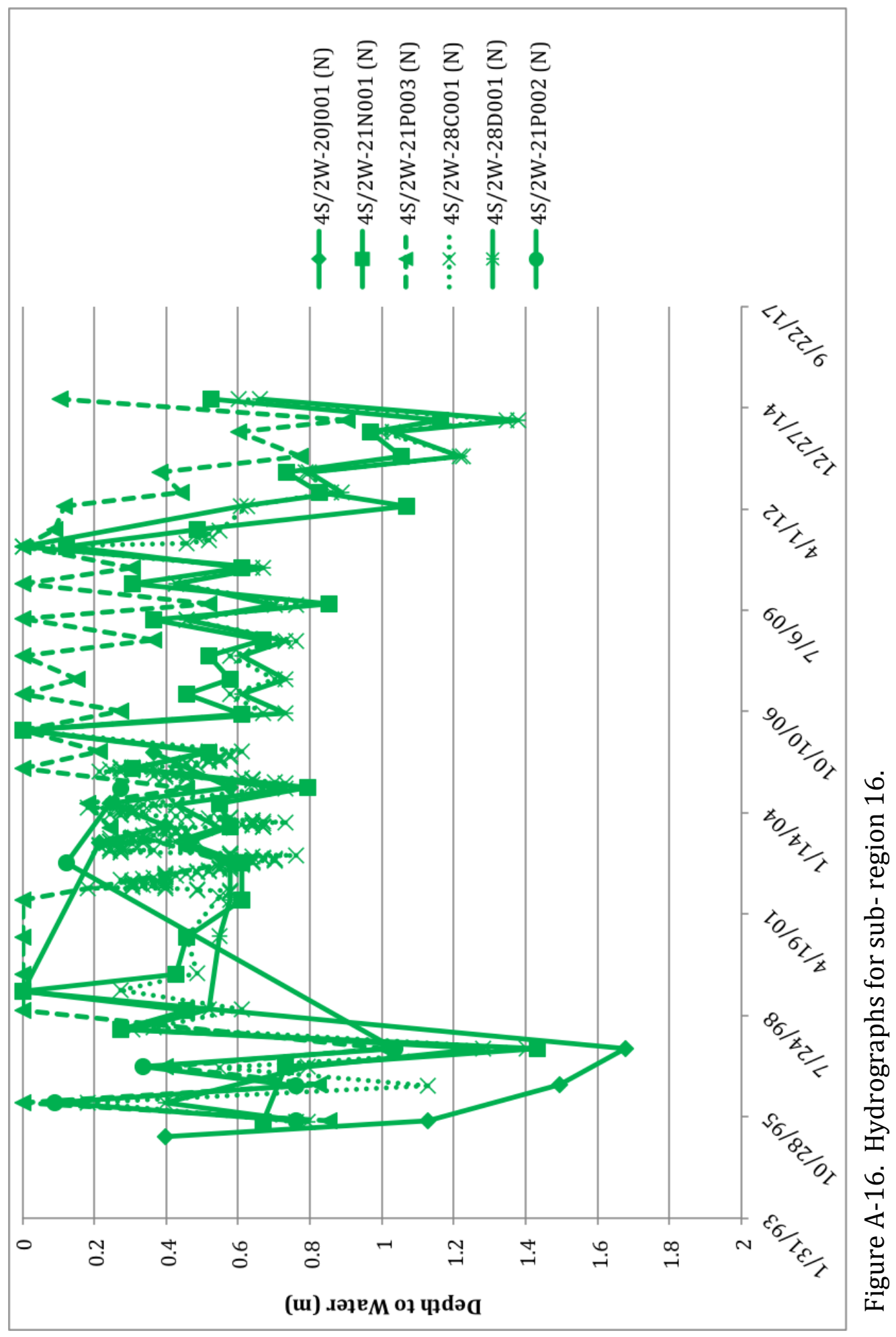




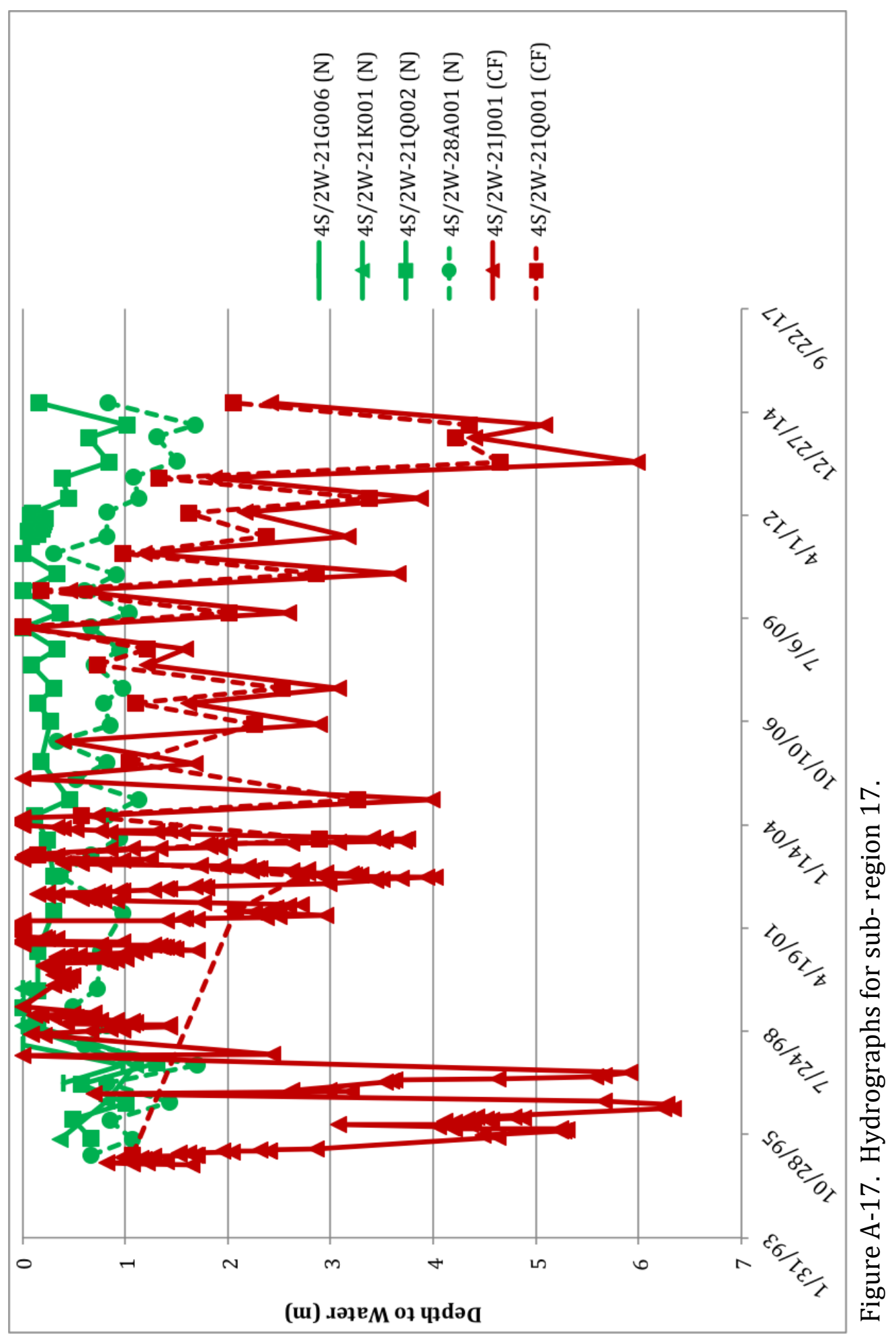




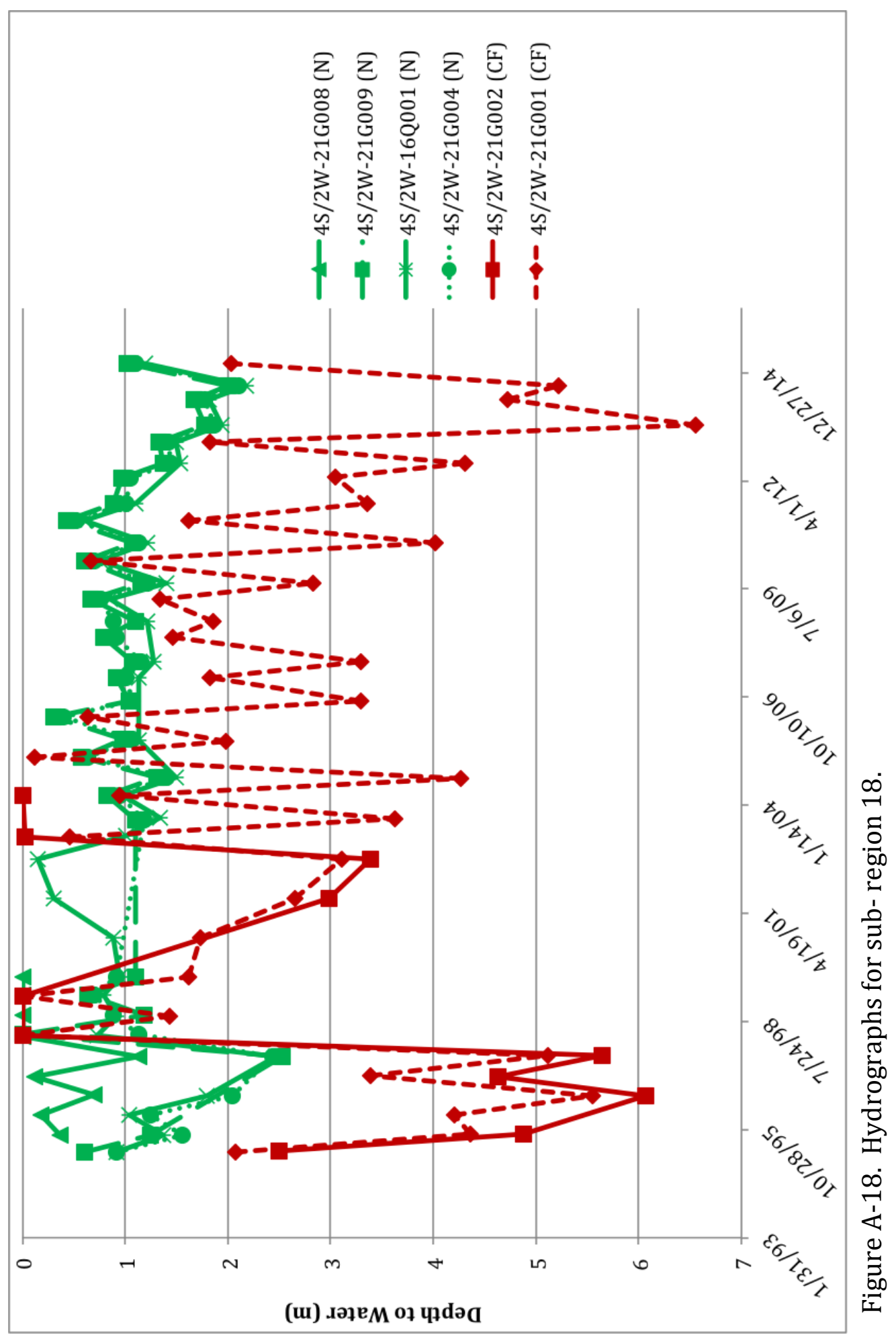




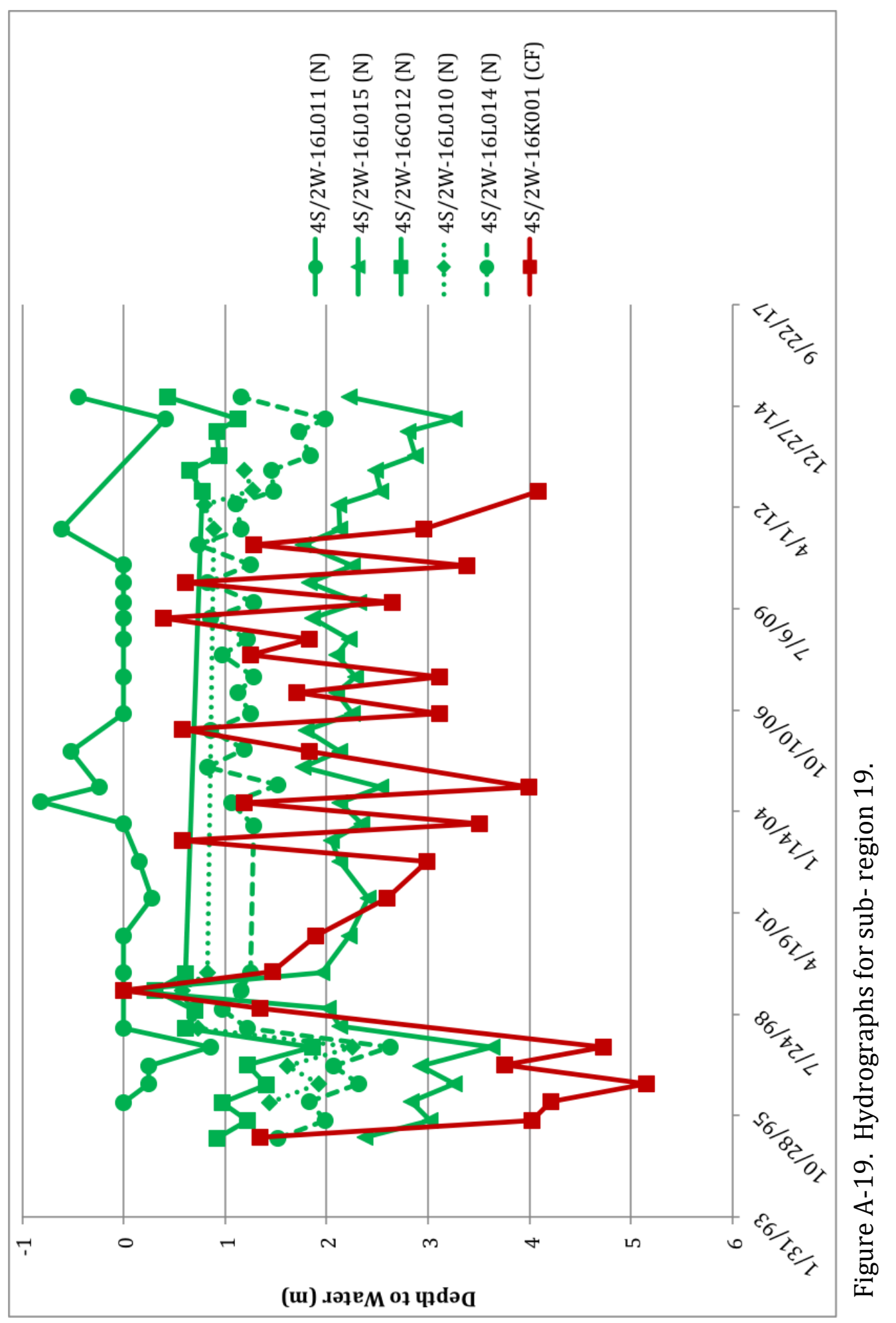




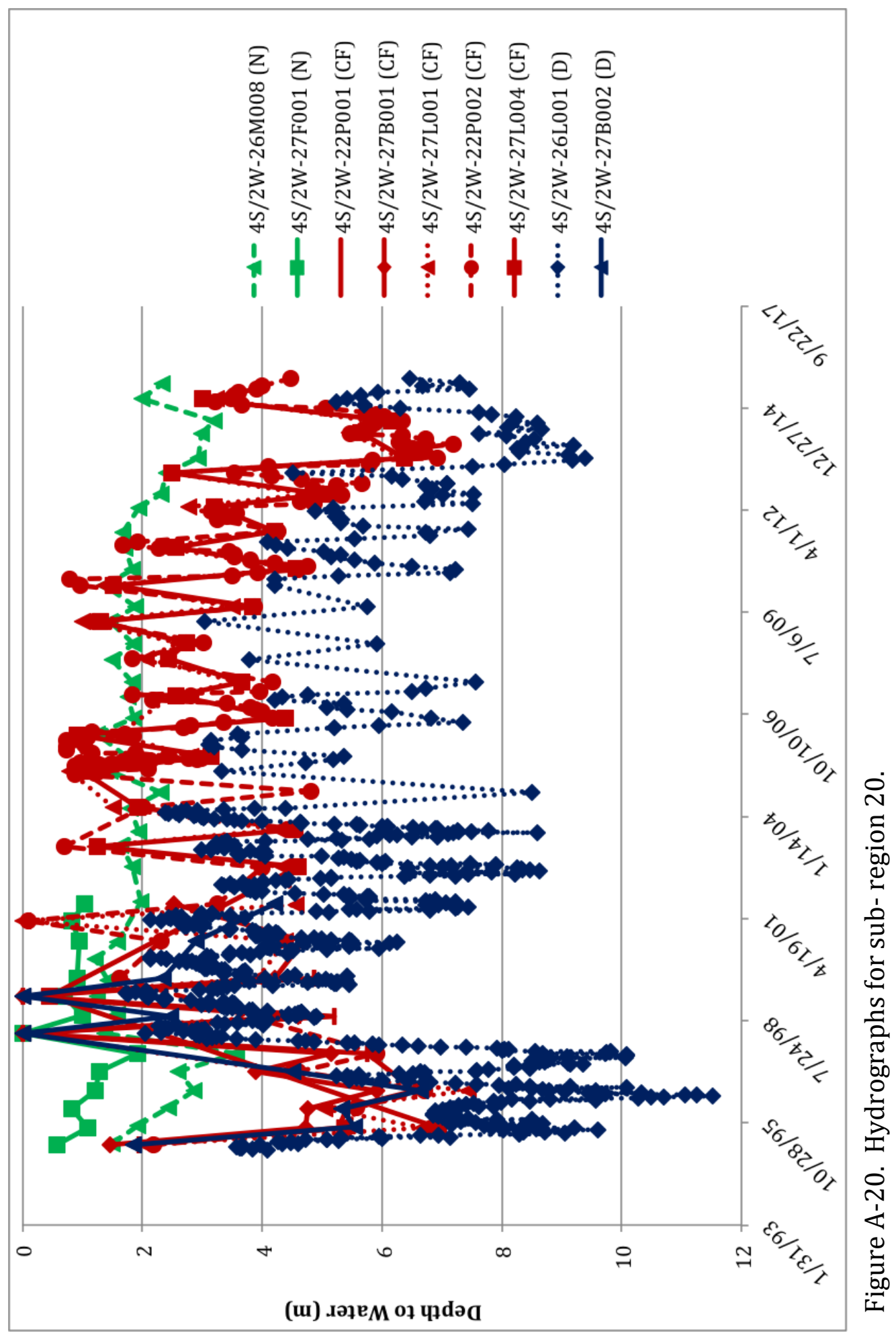




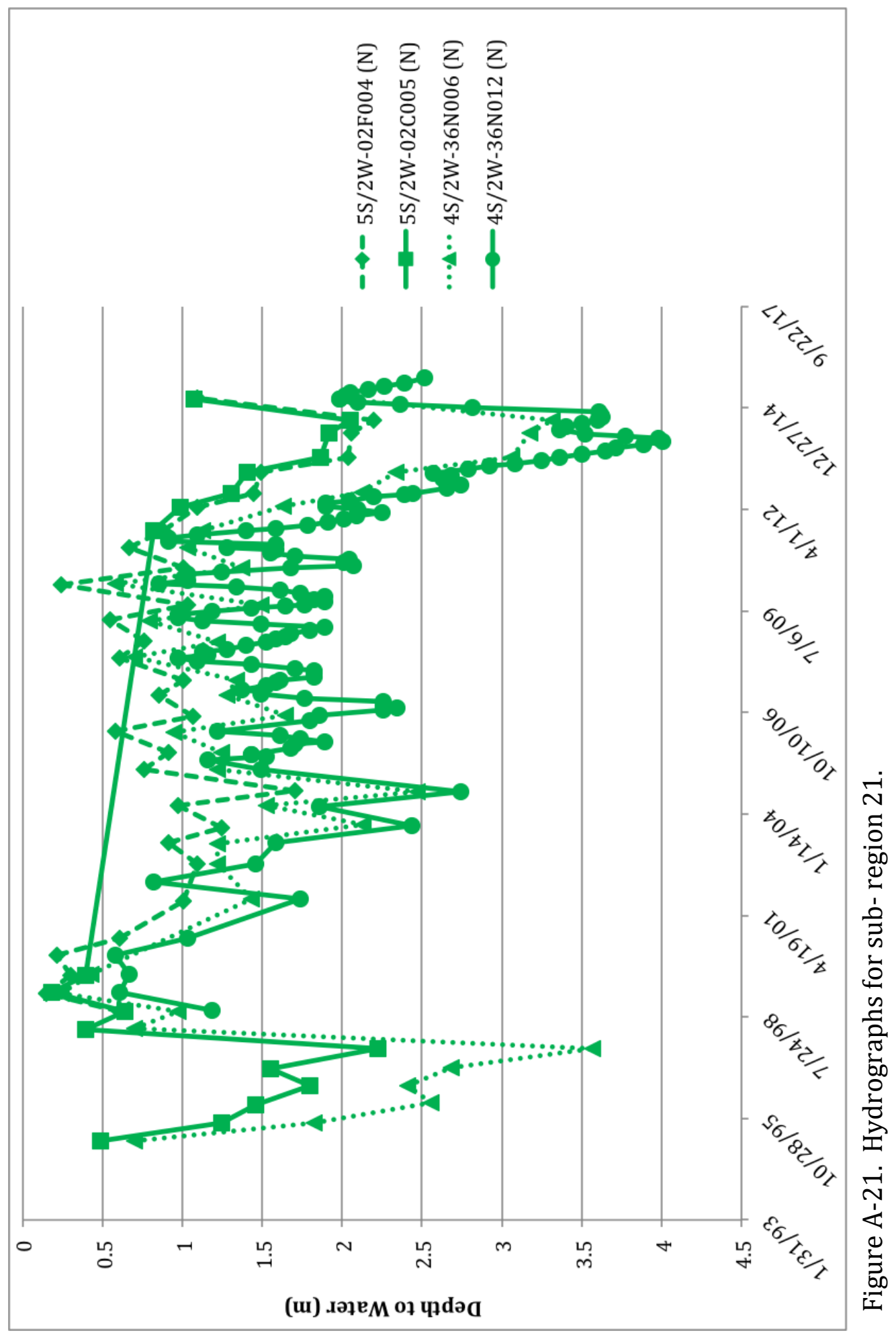




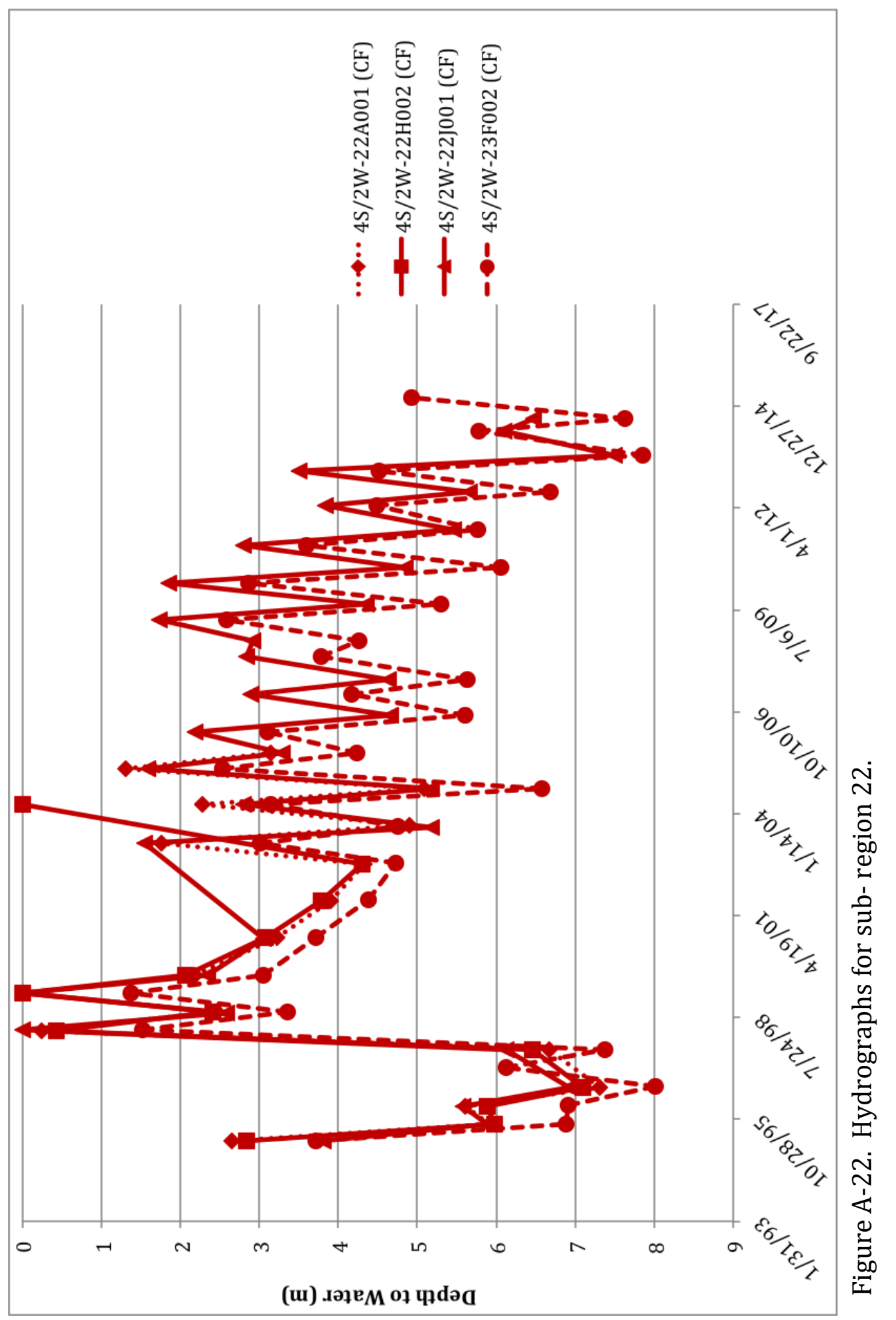




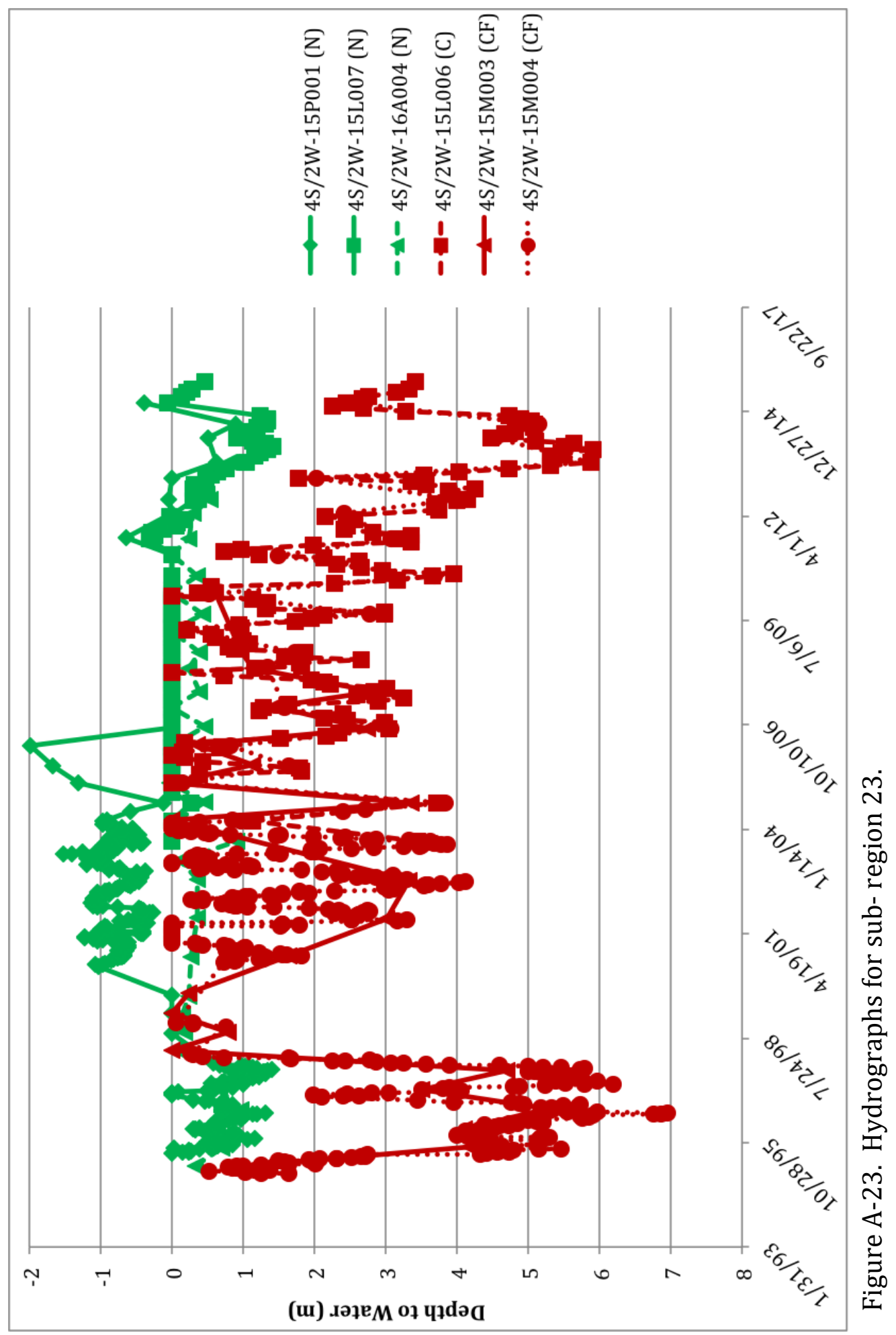




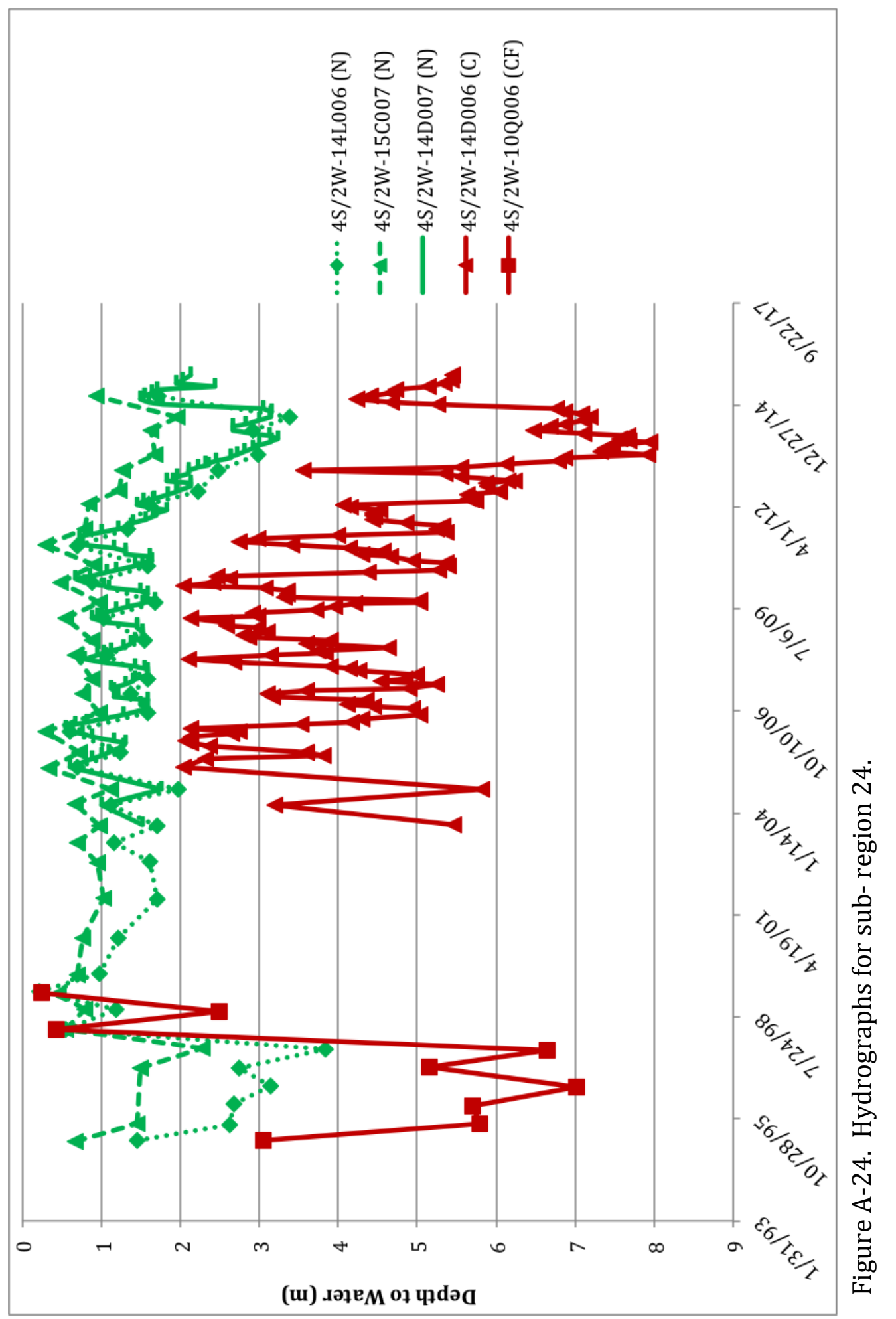

